\title{
ANÁLISE DE ALGUNS ASPECTOS DE DINÂMICA FLORESTAL EM UMA ÁREA DEGRADADA NO INTERIOR DO PARQUE ESTADUAL DO JURUPARÁ, IBIÚNA, SÃO PAULO
}

\author{
Silvana Cristina Pereira Muniz de Souza
}

Dissertação apresentada à Escola Superior de Agricultura "Luiz de Queiroz", Universidade de São Paulo, para obtenção do título de Mestre em Recursos Florestais com opção em Conservação de Ecossistemas Florestais

PIRACICABA

Estado de São Paulo - Brasil

Abril - 2002 


\title{
ANÁLISE DE ALGUNS ASPECTOS DE DINÂMICA FLORESTAL EM UMA ÁREA DEGRADADA NO INTERIOR DO PARQUE ESTADUAL DO JURUPARÁ, IBIÚNA, SÃO PAULO
}

\author{
Silvana Cristina Pereira Muniz de Souza \\ Bióloga
}

Orientador: Prof. Dr. RICARDO RIBEIRO RODRIGUES

Dissertação apresentada à Escola Superior de Agricultura "Luiz de Queiroz", Universidade de São Paulo, para obtenção do título de Mestre em Recursos Florestais com opção em Conservação de Ecossistemas Florestais

PIRACICABA

Estado de São Paulo - Brasil

Abril - 2002 


\section{Dados Internacionais de Catalogação na Publicação (CIP) DIVISÃo DE BIBLIOTECA E DOCUMENTAÇÃO - ESALQ/USP}

\section{So uza, Silvana Cristina Pereira Muniz de}

Análise de algunsaspectos de dinâmic a florestal em uma área degradada no interior do Parque Esta dual do J urupará / $88 \mathrm{p}$. : il.

Dissertação (mestrado) - - Escola Superior de Agricultura Luiz de Queiroz, 2002.

Bibliografia.

1. Banco de sementes 2. Citric ultura 3. Desmatamento 4. Ec ologia florestal 5. Florestasrecupera ção 6. Pastagens 7. Proteção a mbiental I. Título

CDD 634.94

\section{"Permitida a cópia total ou parcial deste documento, desde que citada a fonte - $\mathrm{O}$ autor"}


De dico este trabalho aos meus pais: pelo amor, exemplo de luta e apoio constante. 


\section{AGRADECIMENTOS}

Ao prof. Dr. Ricardo Rodrigues, pela orientação e pela confiança;

Ao Instituto Florestal, em especial a Sueli Herculiani, administradora do Parque, pelo exemplo de luta, incentivo e pela amizade;

À FAPESP, pela bolsa de estudos e pela reserva técnica;

Ao prof. Dr. Sergius Gandolfi pela coorientação, pelas discussões e por sempre enxergar as entrelinhas;

Ao prof. Dr. João L. F. Batista pela ajuda no delineamento amostral e nas análises estatísticas; À professora Jane Kraus pelos primeiros passos no mundo científico e pela amizade;

Aos especialistas consultados pela identificação das espécies: Dra. Natália M. Ivanauskas, Prof. Dr.Vinícius C. Souza, M.Sc. Juliana P. Souza, M.Sc. Geraldo C. Franco, Prof. Dr. Pedro Christoffoleti;

Aos funcionários do Parque: Leonil, Décio, José Faustino, Carlinhos, Ademir, Antonio e em especial ao Sr. Isaias pelo vasto conhecimento transmitido e por ajudar a superar todas as dificuldades em campo;

A Precose (Adriana Rozza) pelas dicas na identificação das sementes;

Aos auxiliares de campo, companheiros de luta, Ana Claúdia, Teflon (Fernando Filho), Fabiana, Murici (Rose Souza), Gabiru (Emanuel Carrollo);

A Maria Luiza e Maria Helena, funcionárias do Instituto Florestal, pela paciência e por sempre estarem dispostas a ajudar.

Aos funcionários do Departamento de Botânica: Teresinha, Chico, Zé e Chadad, por sempre se mostrarem tão prestativos; 
Ao Valmir pelo incentivo inicial, amizade e pelos ideais em comum;

A Inhóq (Viviane Scalon) por me acolher em Piracicaba e pela amizade;

A Murici (Rose Souza), irmã, amiga, companheira, por tudo aquilo que sempre nos uniu;

A Thaty (Natália Ivanauskas), pelas correções, dicas, e principalmente, pelo convívio enriquecedor e pela amizade;

A Claúdia Funi, pelas informações de solo, mapas, informática e pela amizade sempre pronta para ajudar;

Ao Ivo pela paciência e por estar sempre disposto a ajudar;

Aos meninos da casinha, Chifrudo (Vicente), Denis e Edu pelo convívio agradável e a paciência na fase final;

Ao Kamikaze (Rodrigo) pelas referências compartilhadas;

A Mariana e Axé (Marcelo Precoppe) pelas correções do resumo em inglês;

Ao Marcelino C. Guedes, pela ajuda nos testes estatísticos e por nos representar na pós;

Em especial a Alê (Alessandra S. Penha) pela amizade e pelo socorro muito bem vindo na última hora;

E as amigas Ludmila, Flaviana, Marta, Bibiana (Sandra Bibiana), Morena (Marina). 


\section{SUMÁRIO}

Página

RESUMO.......................................................................................... viii

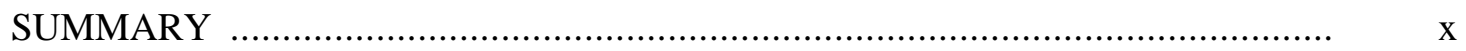

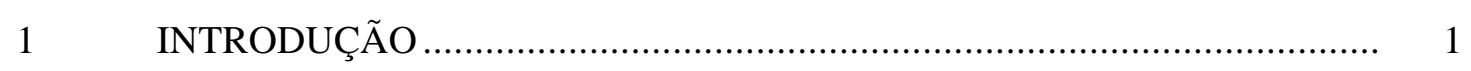

REVISÃO DE LITERATURA ........................................................ 4

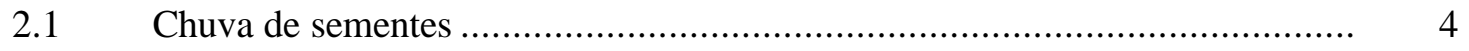

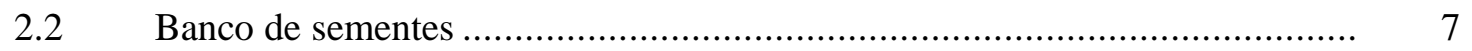

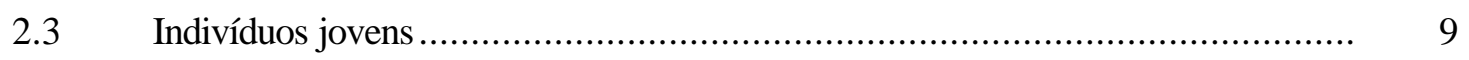

3 A CHUVA DE SEMENTES DE TRECHOS DESFLORESTADOS, ATUALMENTE OCUPADOS COM O CULTIVO DE Citrus sp E COM PASTAGEM, A DIFERENTES DISTÂNCIAS DO REMANESCENTE FLORESTAL NO INTERIOR DO PARQUE ESTADUAL DO JURUPARÁ, IBIÚNA, SP

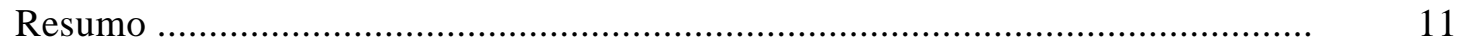

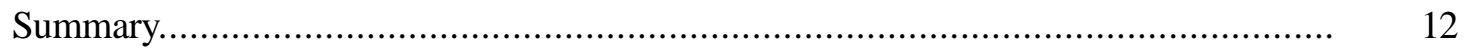

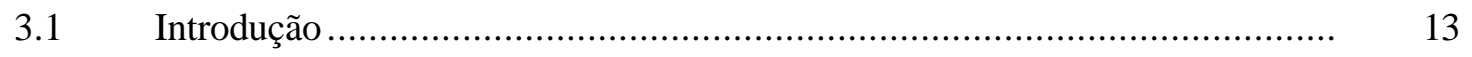

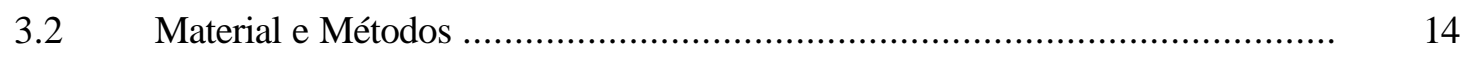

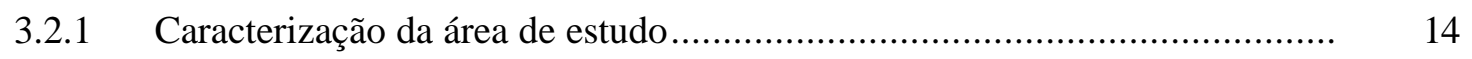

3.2.1.1 Localização geográfica, características edafo-climáticas e vegetacionais ........ 14

3.2.1.2 Caracterização do processo histórico de degradação ................................. 15

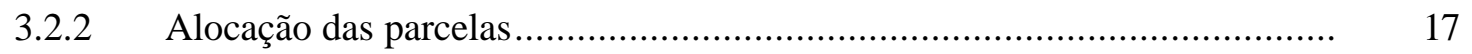

3.2.3 Avaliação da dispersão de sementes.................................................... 17

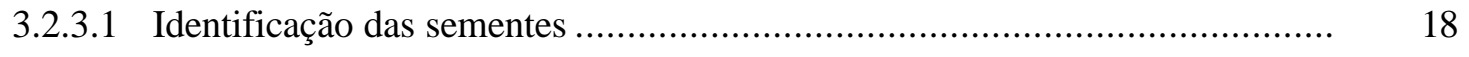

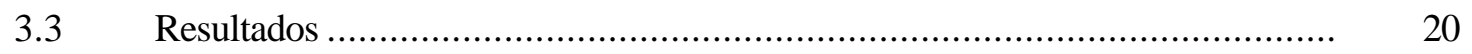

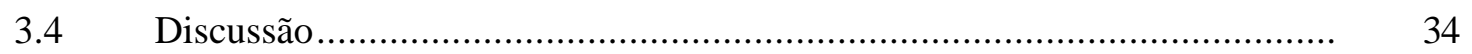

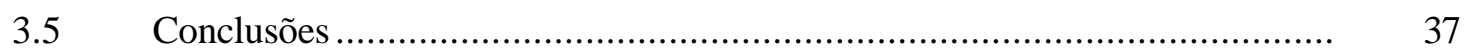


4 O BANCO DE SEMENTES E O ESTRATO DE REGENERAÇÃO DE TRECHOS DESFLORESTADOS, ATUALMENTE OCUPADOS COM O CULTIVO DE Citrus $s p$ E COM PASTAGEM, À DIFERENTES DISTÂNCIAS DO REMANESCENTE FLORESTAL NO INTERIOR DO PARQUE ESTADUAL DO JURUPARÁ, IBIÚNA, SP

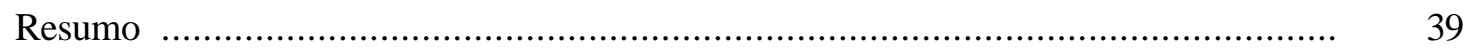

Summary

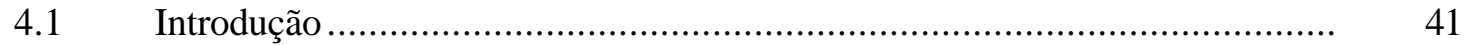

$4.2 \quad$ Material e Métodos .............................................................................

4.2.1 Caracterização da área de estudo ........................................................... 44

4.2.1.1 Localização geográfica, características edafo-climáticas e vegetacionais ........ 44

4.2.1.2 Caracterização do processo histórico de degradação .................................... 44

4.2.2 Alocação das parcelas.......................................................................... 46

4.2.3.1 Banco de sementes ....................................................................

4.2.3.2 Estrato de regeneração.......................................................................... 49

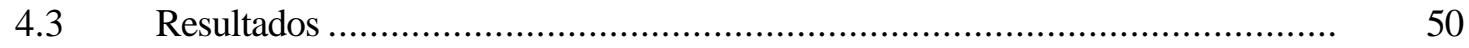

4.3.1 Banco de sementes ......................................................................... 50

4.3.2 Estrato de regeneração.......................................................................... 57

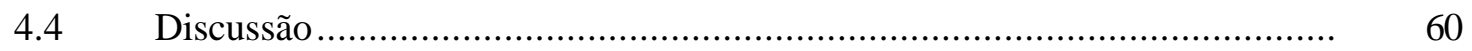

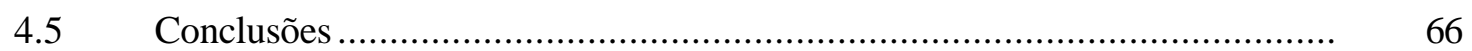

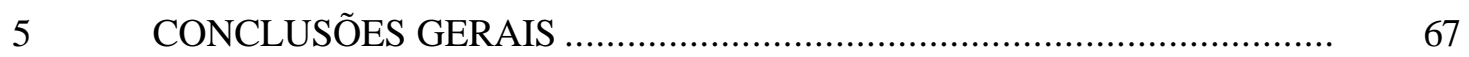

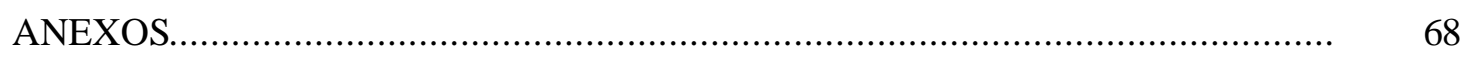

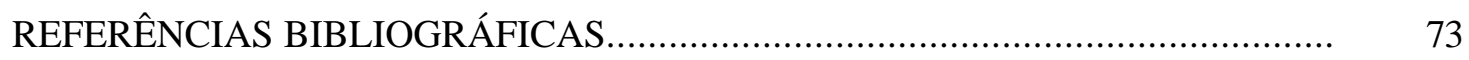




\title{
ANÁLISE DE ALGUNS ASPECTOS DE DINÂMICA FLORESTAL EM UMA ÁREA DEGRADADA NO INTERIOR DO PARQUE ESTADUAL DO JURUPARÁ, IBIÚNA, SÃO PAULO
}

\author{
Autora: Silvana Cristina Pereira Muniz de Souza \\ Orientador: Prof. Dr. Ricardo Ribeiro Rodrigues
}

\section{RESUMO}

O presente trabalho teve como objetivo investigar a resiliência de uma área desflorestada há aproximadamente 20 anos, ocupada atualmente com pastagem e cultivo de Citrus sp. Essa resiliência foi avaliada através dos seguintes aspectos da dinâmica florestal: análise do banco de sementes, da chuva de sementes e de indivíduos jovens regenerantes. Este trabalho foi conduzido no Parque Estadual do Jurupará (2351' S e $47^{\circ} 11^{\prime}$ W), abrangendo os municípios paulistas de Ibiúna e Piedade, em uma região de transição entre a Floresta Ombrófila Densa e a Floresta Estacional Semidecidual. Foram alocadas três faixas de amostragem, cada uma com cinco parcelas aleatorizadas de 10 X $20 \mathrm{~m}$, uma num trecho ocupado com um plantio abandonado de Citrus sp, adjacente ao remanescente florestal, e as restantes num trecho ocupado com pastagem, uma a 0-20 m e outra a 80-100 m de distância do remanescente florestal. Para a avaliação da chuva de sementes, foram lançados aleatoriamente em cada parcela três coletores de sementes circulares de $0,52 \mathrm{~m}$ de diâmetro, com coletas mensais das sementes depositadas. Para a avaliação do banco de sementes foram instalados em cada parcela, três subparcelas de $0,25 \times 0,25 \mathrm{~m}$, para coleta de solo até 0,05 
m de profundidade em duas épocas distintas: estação chuvosa (janeiro/2001) e na estação seca (agosto/2001). Para a avaliação dos indivíduos jovens regenerantes, foram implantadas aleatoriamente 4 subparcelas de $0,5 \times 0,5 \mathrm{~m}$, nas quais foram realizadas três avaliações de todos os indivíduos arbustivos-arbóreos com altura entre 0,30 e 1,30 m. Na avaliação da chuva de sementes na área ocupada com o cultivo de Citrus sp, foi observada alta densidade de sementes autóctones de espécies arbustivo-arbóreas (Leandra sp. com 20.638,73 sem.m ${ }^{-2}$ e Tibouchina sp. com 12.681,85 sem. $\mathrm{m}^{-2}$ ) que ocupavam a área junto com aos indivíduos de Citrus sp. Na pastagem verificou-se a predominância de espécies ruderais, a densidade média das espécies arbustivo-arbóreas foi de $335,75 \mathrm{sem} . \mathrm{m}^{-2}$, na pastagem próxima do remanescente florestal e de 577,58 sem. $\mathrm{m}^{-2}$ na pastagem distante do remanescente florestal. Na avaliação do banco de sementes no cultivo de Citrus sp, as espécies ruderais consistiram em 99,88\% das espécies germinadas na estação chuvosa, e 99,73\% na estação seca. Na pastagem, na estação chuvosa, para as duas distâncias, 100\% das espécies germinadas eram espécies herbáceas tipicamente ruderais; na estação seca esta forma de vida predominou em 99,66\% na área próxima ao remanescente florestal e $99,92 \%$ na área mais distante. No levantamento dos indivíduos jovens regenerantes, encontrou-se densidade 5,8 ind. $\mathrm{m}^{-2}$ na área de Citrus $s p$ e de 1,2 ind. $\mathrm{m}^{-2}$ e 2,2 ind. $\mathrm{m}^{-2}$ na pastagem a $0-20 \mathrm{~m}$ e $80-100 \mathrm{~m}$ de distância do remanescente florestal, respectivamente. Apenas na chuva de sementes foram encontradas diferenças significativas entre a área de Citrus $s p$ e a pastagem, para os demais aspectos analisados não foram encontradas diferenças significativas entre a área de Citrus sp e pastagem. Na pastagem, para todos os apectos analisados, não foram encontradas diferenças significativas entre as diferentes distâncias, rejeitando a hipótese de que a resiliência da pastagem estudada está inversamente relacionada com as distâncias do remanescente florestal nesse trabalho. 


\title{
ANALYSIS OF SOME ASPECTS OF FOREST DYNAMICS IN A DEGRADATED AREA INSIDE THE JURUPARÁ STATE PARK, IBIÚNA, SÃO PAULO STATE
}

\author{
Author: Silvana Cristina Pereira Muniz de Souza \\ Adviser: Prof. Dr. Ricardo Ribeiro Rodrigues
}

\section{SUMMARY}

This work had as a goal identifying the resilience of an area, which was deforested in the past, currently used as pasture and Citrus sp crop. This resilience was evaluated through the following aspects of forest dynamics: soil seed bank analysis, seed rain and saplings. It was conducted in the Jurupará State Park in Ibiúna and Piedade (São Paulo State), in a transition area between the Ombrophil Forest and the Semideciduous Seasonal Forest. In this area, three sampling strips were allocated, each one with five 10 X $20 \mathrm{~m}$ plots, being one inside the Citrus $s p$ crop and the others inside the pasture, distant 0-20 $\mathrm{m}$ and 80-100 $\mathrm{m}$ from the forest remant. For evaluating the seed rain, three circular seeds collectors of $0.52 \mathrm{~cm}$ in diameter were randomly set in each plot, with monthly samplings of the deposited seeds. For evaluating the seed bank, soil of three $0.25 \times 0.25 \mathrm{~m}$ sub-plots and $0.05 \mathrm{~m}$ deep was collected in two different seasons: rainy season (January/2001) and dry season (August/2001). To the saplings evaluation, four $0.5 \times 0.5 \mathrm{~m}$ sub-plots were implanted randomly, in which three evaluations of all the shrubs and trees individuals (0.30-1.30m height) were performed. At the seed rain inside the Citrus $s p$ crop, a high density of autoctone seed of shrubs and trees species (Leandra $s p$. with 20,638.73 seed. $\mathrm{m}^{-2}$ and Tibouchina $s p$. with $12,681.85$ seeds. $\mathrm{m}^{-2}$ ) was observed; inside 
the pasture, there were a predominance of ruderal species, while the average density of shrubs and trees species were, 335.75 seeds. $\mathrm{m}^{-2}$ in the pasture distant $0-20 \mathrm{~m}$ from the remaining forest and 577.58 seeds. $\mathrm{m}^{-2}$ in the pasture distant $80-100 \mathrm{~m}$ from the remaining forest. At the soil seed bank evaluation in the experimental area inside the Citrus sp crop, the ruderal species were $99.88 \%$ of the germinated species in the rainy season and $99.73 \%$ in the dry season. In the experimental area inside the pasture, for the rainy season, $100 \%$ of the germinated species were herbal species typically ruderal in both distances; in the soil collected in the dry season, this life form was predominant in $99.66 \%$ and $99.92 \%$ in both distances, respectively. In the saplings counting, a 5.8 ind. $\mathrm{m}^{-2}$ density inside was found the Citrus sp crop and 1.2 and 2.2 ind. $\mathrm{m}^{-2}$ inside the pasture in both distances. Only for the seeds rain significant differences were found between the Citrus sp crop and the pasture. No significant differences were found between the two distances within the pasture area strips, denying the hypothesis that the resilience of the study area is inversely related to the remaining forest distance. 


\section{INTRODUÇÃO}

A Floresta Tropical vem sendo reduzida continuamente. Segundo a estimativa do "World Resources Institute" (1997), somente durante a década de 1980, 8\% de sua área total foi destruída, e esta porcentagem de destruição manteve-se na última década, apenas com uma leve diminuição (FAO, 1997).

Efeitos globais da degradação das Florestas Tropicais são verificados sobre vários aspectos essenciais na manutenção do equílibrio do planeta, como a ciclagem de carbono (Houghton, 1995), ciclo hidrológico (Lean \& Warrilow,1989; Shukla et al., 1990) e a conservação da biodiversidade (Wilson, 1988).

$\mathrm{Na}$ América Latina, grande parte das áreas florestais são degradadas com o propósito de destiná-las à atividades agropastoris (Amelung \& Diehl, 1992, Fearnside, 1993). Essas áreas são freqüentemente abandonadas devido o declínio na produtividade e mudança nos incentivos econômicos (Uhl et al., 1988; Aide et al., 1995).

O processo de retirada da vegetação e posterior abandono tem levado grandes áreas anteriormente ocupadas por florestas para uma condição de altamente degradadas, que por sua vez, geralmente têm baixa capacidade de auto-recuperação, particularmente aquelas que sofreram intensa perturbação com a agricultura mecanizada (Buschbacher et al.,1988; Uhl et al., 1988).

Estudos realizados em pastagens abandonadas da Amazônia, apontaram que seriam necessários, em média 200 anos, para que áreas que sofreram uso leve retornem à biomassa de uma floresta madura. No entanto, usos leves e uma boa representação de espécies florestais ao redor da área degradada podem fazer com que a altura da floresta seja alcançada mais 
rapidamente (talvez em 100 anos), caso ela não seja infestada intensamente por lianas (Uhl et al., 1988). Por outro lado, algumas áreas de duso mais intensivo requeriam 500 anos ou mais para recuperar sua fisionomia florestal, mesmo assim não assegurando o retorno a uma condição próxima à original, já que áreas que tenham sido utilizadas por muitos anos com fogo freqüente numa região de elevada fragmentação, podem ter sofrido extrema degradação do solo. Quando abandonadas, as características e o nível de degradação destas áreas podem inibir a recuperação da formação de origem, resultando, quando há recuperação, em um ecossistema distinto do original (Aide \& Cavelier, 1994, Cavelier et al., 1998)

Poucos são os trabalhos que investigaram os fatores limitantes à regeneração natural das pastagens na Floresta Tropical (Uhl, 1987; Buschbacher et al., 1988; Nepstad et al., 1991; Aide \& Cavelier, 1994; Fernandes \& Sanford, 1995; Nepstad et al., 1996). Ainda assim, a maioria deles foram realizados na Floresta Tropical Amazônica. Os resultados destes estudos sugerem que um grande número de fatores podem impedir a auto-regeneração de pastagens abandonadas, incluindo a perda de nutrientes e a compactação do solo, competição com gramíneas agressivas, secas periódicas, baixa taxa de chuva de sementes e predação de sementes e plântulas. Entretanto, a importância relativa destes fatores de limitação tem variado muito entre estudos e, em alguns casos, os resultados têm sido contraditórios (Holl, 1999).

Para melhor compreensão desses processos, há a necessidade de identificar a trajetória percorrida durante a degradação, já que a intensidade e longevidade das perturbações irão determinar a resiliência do ecossistema, que pode ser entendida como o potencial ou a capacidade de regeneração de um ecossistema após uma degradação (Aronson et al., 1995).

Estudos localizados são essenciais para se obter informações sobre o histórico de degradação da área e identificar os fatores limitantes para, desta forma, subsidiar o estabelecimento de métodos de baixo custo, visando acelerar a sua restauração com elevada eficiência ecológica (Holl, 1999)

Diante da escassez de trabalhos no domínio da Floresta Tropical Atlântica que busquem explicar como atuam os principais fatores limitantes da regeneração natural após 
perturbações antrópicas e, em específico, das áreas ocupadas por atividades agropastoris. Este trabalho tem como hipótese que a resiliência de áreas desflorestadas, é definida pelas características vegetacionais da matriz degradada e está inversamente relacionada com a distância do remanescente florestal.

O objetivo geral deste trabalho é identificar alguns aspectos de regeneração natural, visando subsidiar a adequação das práticas de conservação, manejo e restauração de áreas degradadas no interior do Parque Estadual do Jurupará. Dentro desta proposta os objetivos específicos são avaliar a resiliência do componente arbustivo-arbóreo e herbáceo em curso numa pastagem abandonada a duas distâncias do remanescente florestal e numa área de cultivo de Citrus sp, as duas dentro de uma matriz florestal remanescente, através da análise dos seguintes aspectos: chuva de sementes, banco de sementes e indivíduos jovens regenerantes. 


\section{REVISÃO DE LITERATURA}

A compreensão dos fatores que afetam a regeneração das Florestas Tropicais após perturbações antrópicas podem ajudar a desenvolver caminhos para sua restauração (Duncan

\& Chapman, 1999), como também contribuir com conhecimentos sobre o mecanismo de sucessão (Pickett et al., 1987)

Em pastagens sujeitas a uso intensivo e altamente degradadas, foram observados vários os fatores que limitaram o estabelecimento de espécies florestais, tais como a dispersão de sementes, a predação de sementes e plântulas, a competição entre espécies e a seca sazonal, além da falta de agentes dispersores (Uhl et al., 1981).

A regeneração da vegetação tropical em pastagens abandonadas é limitada por todos os estágios sucessionais iniciais: colonização, estabelecimento, crescimento e sobrevivência (Holl, 1999). Contudo, um aumento na chuva de sementes pode não resultar necessariamente em um aumento no recrutamento (Holl, 1998).

Conhecimentos sobre a importância do banco e da chuva de sementes são essenciais para o entendimento da regeneração natural em áreas florestais desmatadas e utilizadas para atividades agropastoris. Estas áreas degradadas apresentam quatro fontes potenciais de regeneração: sementes presentes no solo antes do distúrbio, entrada de sementes pela chuva de sementes e brotamento de raízes e troncos (Young et al., 1987).

\subsection{Chuva de sementes}


A entrada, o fluxo ou a "chuva" de sementes ou de propágulos para uma determinada área é fundamental na determinação da população potencial em um habitat; suas características dependem da distância e da concentração de fontes produtoras de propágulos, dos atributos de dispersão apresentados pelos propágulos e dos agentes de dispersão (Harper, 1977).

O estudo da dinâmica da chuva de sementes é essencial para a compreensão dos processos de recrutamento, da estrutura e da distribuição espacial das populações de adultos presentes numa determinada área. Entretanto, deve-se ressaltar que a colonização efetiva de um habitat depende de uma ampla quantidade de fatores, além da dispersão das sementes (Willson, 1993).

Algumas questões a respeito da chuva de sementes ainda não estão claras, já que pouco se sabe a respeito da variação da chuva de sementes no espaço e no tempo, e mesmo o significado da chuva contínua de sementes ainda não é compreendido. Whitmore (1989), hipotetizou que a restauração da condição de floresta sobre campos limpos é freqüentemente inibida por falta de fonte de sementes ou vetores de dispersão.

O padrão de distribuição das sementes de uma dada área é influenciado pela chuva de sementes, que tem por variáveis o peso da semente, a eficiência da dispersão, a quantidade de adultos reprodutivos no local, entre outros. Quase toda chuva de sementes mostra um modelo agregado, indicando que a dispersão tende a declinar logaritmicamente com o aumento da distância (Hutchings, 1986; Miles, 1979). No entanto, a probabilidade de mortalidade, causada por predadores de sementes, herbívoros de plântulas e fungos patogênicos aumenta com a proximidade da planta-matriz e diminui com o aumento da distância (Janzen, 1970). No entanto, o risco da mortalidade de sementes e plântulas devido a predadores e patógenos é função da densidade, em vez da distância (Connell, 1979 apud Hutchings, 1986).

A dispersão anemocórica em espécies pioneiras e não-pioneiras tende a produzir uma distribuição mais distante da árvore matriz, em relação às espécies dispersas por vertebrados (Willson, 1993; Willson \& Crome, 1989). Há também diferenças na distância de dispersão em conseqüência das diferenças de tamanho das sementes e tipos de agentes dispersores (Dalling et al., 1997). 
No que se refere à colonização em grandes áreas degradadas, as sementes grandes têm maior probabilidade de sobreviver a todas fases do estabelecimento do que as sementes pequenas. No entanto, elas apresentam maior dificuldade para alcançar naturalmente as pastagens degradadas já que são, geralmente, zoocóricas. Em uma primeira fase, apenas as espécies com sementes pequenas e leves podem se estabelecer em áreas degradadas (Uhl et al., 1991).

Segundo alguns estudos, barreiras na dispersão de sementes parecem ser fatores muito importantes na limitação da regeneração natural em pastagens abandonadas (Holl,1999). A grande maioria das sementes da Floresta Tropical tem adaptações para dispersão animal (Howe, 1984), mas muitos pássaros e mamíferos da Floresta Tropical raramente se aventuram dentro de áreas abertas (Silva et al., 1996; Holl \& Lulow, 1997).

Segundo Duncan et al. (1999), os dispersores de sementes evitam áreas limpas devido ao risco de predação; desta forma, a chuva de sementes pode estar negativamente correlacionada com a distância da borda da floresta.

Há diferenças evidentes entre a chuva de sementes em clareiras no interior da floresta e em áreas abertas por perturbações antrópicas. Um experimento com chuva de sementes zoocóricas numa pastagem abandonada com um remanescente florestal m entorno, mostrou que a maioria das sementes coletadas foram de árvores e arbustos que tipicamente crescem em pastagens perturbadas e áreas de agricultura, não em clareiras na floresta (Duncan et al.,1999). Também foi verificada uma relação negativa entre a chuva de sementes e a distância da borda da floresta, sugerindo que a distância pode ser um fator importante no início da sucessão florestal (Myster \& Pickett, 1992).

A sucessão nas pastagens abandonadas é dependente das sementes da floresta dispersas recentemente (Holl, 1999), já que as sementes da maioria das espécies da Floresta Tropical perdem rapidamente a viabilidade. Entretanto, sementes das espécies da floresta são raramente encontradas na pastagem recentemente abandonada (Garwood, 1989; VázquezYanes \& Orozco-Segovia, 1993). 
A chegada de sementes é apenas o primeiro passo nas várias fases do processo de condução do estabelecimento de árvores (Duncan et al. 1999). Fatores pós-dispersão, como a predação, modificam o recrutamento depois da chegada de sementes (Willson and Whelan, 1990).

Há um grande potencial de regeneração florestal de pastagens abandonadas a partir de ilhas de floresta natural. O reflorestamento torna-se então um processo de multiplicação de ilhas de floresta, pelo estabelecimento de árvores que atraem agentes dispersores e criam condições favoráveis para o estabelecimento de plântulas de espécies arbóreas debaixo do seu dossel (Uhl et al., 1991).

\subsection{Banco de sementes}

O termo banco de sementes é utilizado para designar a reserva de sementes viáveis presentes no solo e na sua superfície, sendo que, o primeiro pesquisador que trabalhou com o banco de sementes foi Darwin em 1859 (Roberts, 1981). No entanto, o primeiro trabalho detalhado sobre as sementes do solo foi realizado por Putensen em 1882, que examinou a ocorrência de sementes presentes no solo a três profundidades (Roberts,1981). A partir do início do século $\mathrm{XX}$, pesquisas com as populações do banco e técnicas para quantificá-las foram realizadas em vários continentes com diferentes tipos vegetacionais.

$\mathrm{Na}$ década de 60, pesquisadores enfatizaram a importância de considerar as sementes presentes no solo como parte da flora (Major e Pyott,1966 apud Roberts, 1981). No entanto, apenas a partir de 1980 é que foi dada a devida atenção ao banco de sementes e ao seu papel na regeneração de habitats naturais (Roberts, 1981).

Desde os primeiros trabalhos com banco de sementes em regiões tropicais, obteve-se sempre o mesmo resultado: o banco de sementes tende a ser dominado por uma ou poucas espécies (Garwood, 1989) e ser constituído, basicamente, por espécies pioneiras herbáceas e

arbustivo-arbóreas de ciclo de vida curto (Putz \& Appanah, 1987; Baider et al., 1999). Espécies herbáceas pioneiras não são componentes das florestas tropicais, mas aparecem em 
grande número no banco de sementes pois, geralmente, apresentam dormência facultativa, além de possuírem mecanismos eficientes de dispersão (Hopkins \& Graham, 1984; Vázquez-Yanes \& Orozco-Segovia, 1987; Whitmore, 1989; Baider et al., 1999).

A dormência é mais comum nas sementes das espécies pioneiras do que nas de clímax, já que estas últimas, geralmente, germinam sob o dossel logo após a dispersão, pois estão sujeitas a uma grande pressão de predação, e possuem reservas suficientes, conferindo certa independência para o estabelecimento de plântulas (Whitmore, 1990). Normalmente, as sementes de espécies mais finais da sucessão não possuem capacidade de dormência e raramente são encontradas no banco, estando associadas principalmente ao banco transitório. O tamanho da semente implica em menor produção e a dispersão pode ser menos efetiva, ou seja, mais próxima da planta matriz (Harper, 1977).

Diferenças na dispersão e dormência das sementes, características entre espécies mais iniciais da sucessão, refletem na variação espacial e temporal da composição do banco de sementes (Dalling et al., 1997).

Entre as espécies pioneiras, a duração da dormência das sementes presentes no solo varia bastante. Experimentos nos quais foi estimada a sobrevivência de sementes mostraram que $100 \%$ das sementes de algumas espécies pioneiras podem permanecer no solo sem germinar pelo período de dois anos, enquanto que outras espécies apresentaram marcada redução na germinabilidade depois de um ano. (Hopkins \& Graham, 1987)

A densidade de sementes encontradas no estudo do banco de sementes é dependente da profundidade do solo estudado, da sazonalidade e da distância da fonte de propágulos. Dailling et al. (1997), estudando o banco de sementes da Floresta Tropical observaram um declínio de número e riqueza de sementes presentes no solo, conforme se aumentava a profundidade. Esta tendência também foi verificada em outros trabalhos (Putz, 1983; Young, 1985).

Dailling et al. (1997), verificou a influência da sazonalidade no número e riqueza de sementes, encontrando uma diminuição na germinação nos meses mais úmidos, provavelmente como resultado da mortalidade das sementes causada por patógenos como fungos e bactérias. 
A distância da fonte de propágulos pode influenciar a densidade de espécies pioneiras presentes no banco. Em estudos conduzidos na Floresta Tropical, foi verificado que a densidade de sementes das espécies pioneiras declina logaritmicamente com a distância da copa da árvore matriz (Alvarez-Buylla \& Martínez Ramos, 1990; Dailling et al. 1997).

\subsection{Indivíduos jovens}

No interior da floresta, após a dispersão, um grande número de propágulos alcança o solo; entretanto, somente uma pequena fração germina e consegue atingir o estádio de plântula (Harper, 1977). Em uma etapa posterior, indivíduos jovens de espécies do dossel da floresta madura ocupam transitoriamente o subosque (Brokaw, 1985)

O banco de plântulas e de indivíduos jovens, que constituem a chamada regeneração avançada, parecem ter maior importância na regeneração da floresta após a abertura de clareiras pequenas $\left(<150 \mathrm{~m}^{2}\right)$ do que os diásporos externos, oriundos da chuva de sementes e daquelas presentes no estoque do solo. Em um estudo realizado na Venezuela, 95\% das árvores encontradas em clareiras pequenas, após quatro anos da sua formação, eram resultantes da regeneração avançada (Uhl et al., 1988).

Uma explicação para esse tipo de estratégia seria para evitar a predação, já que as sementes e os frutos de muitas espécies de florestas tropicais maduras são grandes e tem alto valor nutricional, tornando-se excelentes recursos para herbívoros (Vazquez-Yanes \& OrozcoSegovia, 1987).

Nas regiões tropicais, apesar dos poucos estudos, parece que a sobrevivência de plântulas, em alguns casos, aumenta com a distância da planta matriz (Howe \& Smallwood, 1982), porque haveria diminuição dos possíveis fatores de mortalidade, que dependem da densidade e/ou distância (Janzen, 1970; Connell, 1979 apud Hutchings, 1986), como patógenos (Augspurger, 1983), predadores pós-dispersão (Janzen, 1970), herbívoros (Osunkjova et al., 1992), alelopatia, competição entre a prole e a planta-matriz (Harper, 1977) 
e por nutrientes e luz (Fenner, 1978). No entanto, há outros estudos em que foi observada maior sobrevivência próxima à planta-matriz (Leite et al., 1982).

Nas condições geralmente inóspitas das grandes clareiras, e principalmente nas situações de pastagens abandonadas, o estrato de regeneração é raramente observado. Estes são mais freqüentemente observados nestas áreas ao redor de árvores remanescentes, constituindo as ilhas de floresta natural (Uhl et al., 1991).

A maioria dos trabalhos relacionados com a investigação dos processos envolvidos na dinâmica florestal negligencia a composição dos estratos inferiores, compostos por indivíduos de espécies características deste estrato (Laska, 1997) e por indivíduos jovens de espécies arbóreas que representam as fontes de regeneração das florestas (Swaine, 1996)

Grombone-Guaratini (1999), estudando o estrato de regeneração de uma Floresta Estacional Semidecidual, verificou que 53,6\% das espécies encontradas são ocupantes temporárias deste estrato, ou seja, indivíduos jovens de espécies do dossel e emergentes. 


\title{
A CHUVA DE SEMENTES DE TRECHOS DESFLORESTADOS, ATUALMENTE OCUPADOS COM O CULTIVO DE Citrus sp E COM PASTAGEM, A DIFERENTES DISTÂNCIAS DO REMANESCENTE FLORESTAL NO INTERIOR DO PARQUE ESTADUAL DO JURUPARÁ, IBIÚNA, SÃO PAULO
}

\author{
Autora: Silvana Cristina Pereira Muniz de Souza \\ Orientador: Prof. Dr. Ricardo Ribeiro Rodrigues
}

\section{Resumo}

A resiliência de uma área degradada próxima a um remanescente florestal foi avaliada no interior do Parque Estadual do Jurupará (2351' S e $47^{\circ} 11^{\prime}$ W) através da chuva de sementes, durante o período de um ano em uma região de transição entre a Floresta Ombrófila Densa e a Floresta Estacional Semidecidual. Nesta área foram alocadas três faixas de amostragem, cada uma com cinco parcelas aleatorizadas de 10 X $20 \mathrm{~m}$, uma no interior do cultivo de Citrus sp, e as restantes na pastagem a $020 \mathrm{~m}$ e 80-100 m de distância do remanescente florestal. Em cada parcela foram lançados aleatoriamente três coletores de sementes circulares de $0,52 \mathrm{~m}$ de diâmetro (área de $0,2123 \mathrm{~m}^{2}$ ) totalizando 15 coletores por faixa e 45 coletores nas três faixas experimentais, com um total de $9,5535 \mathrm{~m}^{2}$ de área de coleta de sementes. Mensalmente, pelo período de um ano os coletores tiveram o material depositado coletado. Neste período, foram depositadas 125.214 sementes de 99 espécies amostradas, sendo que na área de cultivo de Citrus sp foram depositadas 106.811 sementes com densidade absoluta de 33.546,17 sem.m² ${ }^{-2}$, com a predominância das sementes de espécies arbustivas-arbóreas autóctones (Leandra sp com 20.638,73 sem.m ${ }^{-2}$ e Tibouchina sp com 
12.681,85 sem. $\mathrm{m}^{-2}$ ), que ocupavam as linhas e entrelinhas do cultivo abandonado de Citrus sp. No interior da pastagem verificou-se a predominância de espécies ruderais. A densidade média das espécies arbustivas-arbóreas foi de 335,75 sem. $\mathrm{m}^{-2}$ na pastagem próxima do remanescente florestal, e de 577,58 sem. $\mathrm{m}^{-2}$ na pastagem distante. Houve a predominância de sementes com dispersão zoocórica $(61,79 \%)$ na área de Citrus sp, e de sementes com dispersão anemocórica nas áreas de pastagem próximas $(94,4 \%)$ e distantes $(74,7 \%)$ dos remanescentes florestais. Foram encontradas diferenças significativas entre a área de Citrus sp e de pastagem; no entanto, não foram encontradas diferenças significativas entre as duas distâncias do remanescente florestal na pastagem, rejeitando a hipótese de que a dispersão de sementes está inversamente relacionada com a distância do remanescente florestal.

\title{
THE SEED RAIN IN DEFORESTED AREAS, CURRENTLY USED WITH Citrus $s p$ CROPS AND PASTURE, IN DIFFERENT DISTANCES FROM THE REMAINING FOREST, INSIDE THE JURUPARÁ STATE PARK, IBIÚNA, STATE SÃO PAULO
}

\author{
Author: Silvana Cristina Pereira Muniz de Souza \\ Adviser: Prof. Dr. Ricardo Ribeiro Rodrigues
}

\section{Summary}

The resilience of a degraded area next to a remaining forest was evaluated inside the Jurupará State Park through seeds rain within a year, in a transition area between the Ombrophil Forest and the Semideciduous Seasonal Forest. In this area, three sampling strips were allocated, each one with five parcels measuring $10 \times 20 \mathrm{~m}$, being one inside the Citrus $s p$ crop and the others inside the pasture distant 0-20 $\mathrm{m}$ and $80-100 \mathrm{~m}$ from the remaining forest. In each parcel, three circular seeds collectors of $0.52 \mathrm{~cm}$ in diameter were randomly set, with a collect area of $0.2123 \mathrm{~m}^{2}$ each. Considering the three experimental strips there were 15 collectors/strip and 45 collectors in all. Monthly, within a year, the deposited material from the 
collectors was taken. In this period, 125,214 seeds were deposited with 99 sampled species. In the Citrus sp crop area, 106,811 seeds were deposited with absolute density of 33,546.17 seeds.m-2, with a predominance of autoctone shrubs-arboreal species seeds (Leandra $s p$ with 20,638.73 seeds. $\mathrm{m}^{-2}$ and Tibouchina $s p$ with 12,681.85 seeds.m-2); inside the pasture it was observed a predominance of ruderal species and the average density of shrubs-arboreal species was, 335.75 seeds. $\mathrm{m}^{-2}$ in the pasture distant $020 \mathrm{~m}$ from the remaining forest, and 577.58 seeds. $\mathrm{m}^{-2}$ in the pasture distant $80-100 \mathrm{~m}$ from the remaining forest,. There was a predominance of seeds with zoochoric dispersion (61.79\%) in the Citrus sp crop area. In the pasture there was a predominance of seeds with anemochoric dispersion with $94.43 \%$ in the nearest area and $79.71 \%$ in the farthest one. Significant differences between the Citrus sp crop and the pasture were found, but no significant differences between the two distances were found, denying the hypothesis that the dispersion of seeds is inversely related to the remaining forest distance.

\subsection{Introdução}

A avaliação da dispersão de sementes em áreas degradadas é de grande importância para identificar o potencial de regeneração natural dessas áreas e para definir a metodologia de recuperação, principalmente em áreas degradadas que têm no seu entorno fragmentos remanescentes (Rodrigues \& Gandolfi, 2000). Através dessa informação, é possível ainda estabelecer relação com o tamanho e a composição do banco de sementes (Thompson, 1993).

A regeneração em pastagens abandonadas é geralmente dependente da dispersão de propágulos provenientes de espécies ocorrentes nos remanescentes florestais do entorno, pois muitas das sementes da Floresta Tropical têm viabilidade curta e, por isso, não são encontradas no banco de sementes (Uhl, 1987; Garwood, 1989; Nepstad et al., 1996)

Previsões empíricas (Willson \& Crome, 1989) e estudos teóricos (Greene \& Johnson, 1996) sugerem que o número de sementes dispersas pelo vento declina em relação à distância da borda da floresta. 
Estudos demonstraram claramente que a falta de dispersão de sementes é um dos fatores que mais limitam a regeneração natural em pastagens abandonadas: poucas sementes de espécies arbóreas dispersas por animais caem além dos $5 \mathrm{~m}$ da borda da floresta em áreas de pastagem sem árvores ou arbustos (Willson \& Crome, 1989, Whitmore, 1989; Aide \& Cavelier, 1994; Vieira et al., 1994; Holl, 1999). A grande maioria das sementes da Floresta Tropical tem adaptações para dispersão animal (Howe, 1984); no entanto, poucos pássaros e mamíferos da Floresta Tropical se aventuram dentro de áreas abertas (Silva et al., 1996).

Tanto as espécies pioneiras quanto as clímax exibem diferenças na distância de dispersão, em consequência das diferenças de tamanho das sementes e tipos de agentes dispersores (Dalling et al., 1997).

Este estudo testa as hipóteses de que a dispersão de sementes sofre influência do tipo de cobertura vegetal e está inversamente relacionada na pastagem com a distância do remanescente florestal. Dessa forma, o objetivo foi avaliar a chegada de propágulos no interior do cultivo de Citrus sp e na pastagem, sendo esta última avaliada a diferentes distâncias do remanescente florestal.

\subsection{Material e métodos}

\subsubsection{Caracterização da área de estudo}

\subsubsection{Localização geográfica, características edafo-climáticas e vegetacionais}

O Parque Estadual do Jurupará está localizado no Estado de São Paulo na região do Vale do Ribeira, sobre o Planalto Atlântico (Alencar et al., 1976). Abrange os municípios de Ibiúna e Piedade, com uma área de 26.250,47 ha, com coordenadas geográficas $23^{\circ} 51^{\prime}$ a $24^{\circ} 02^{\prime}$ 'S e $47^{\circ} 11^{\prime}$ a $47^{\circ} 24^{\prime} \mathrm{W}$ (Anexo A).

A temperatura média anual é de $22^{\circ} \mathrm{C}$ e a precipitação pluviométrica anual oscila

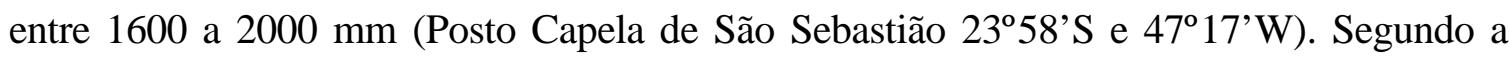


classificação de Köeppen (1948), o clima é do tipo Cfb, quente de inverno seco (Alencar et al., 1976; Aoki, 1982).

Os solos predominantes são: LATOSSOLO VERMELHO-AMARELO Distrófico câmbico (LVAd) de textura argilosa e o CAMBISSOLO HÁPLICO Tb Distrófico (CXvd) de textura argilosa ou argilosa com cascalhos. (Oliveira et al., 1999)

A vegetação local é considerada transicional entre a Floresta Ombrófila Densa e Floresta Estacional Semidecidual (Aragaki \& Mantovani, 1998).

\subsubsection{Caracterização do processo histórico de degradação}

As terras que compõem o Parque Estadual do Jurupará são devolutas, portanto pertencentes ao Estado de São Paulo. Em 1978, devido às características ambientais da área, parte do $2^{\circ}$ Perímetro de São Roque foi transformado em Reserva Estadual, sendo conhecida como Reserva Estadual do $2^{\circ}$ Perímetro de São Roque. Em 1992, esta Reserva foi transformada no Parque Estadual do Jurupará pelos decretos nீ 35.703 e 35.704, estando, atualmente, sob a administração do Instituto Florestal. No entanto, a questão fundiária desta Unidade de Conservação é complexa já que se encontra quase que completamente ocupada por pequenas propriedades.

A partir de 1978, todas as intervenções praticadas no interior da Unidade de Conservação já eram consideradas irregulares e, em virtude de impactos ambientais praticados

por um dos ocupantes do Parque e em decorrência de ação civil pública em 1998, houve a reintegração de posse pelo Estado de três fazendas, Sete Lagos, Tucano e Km 40, somando aproximadamente 800 ha sob o domínio do Instituto Florestal

A área experimental deste trabalho localiza-se no interior da antiga Fazenda Tucano, que desde da década a 70 vem sofrendo degradação antrópica, que se intensificou a partir de 1985, com o corte de extensas áreas de floresta nativa, seguido de queima. Grande parte 
destas áreas, logo após a degradação, foram destinadas para atividades agropastoris, com a predominância de utilização para pastagens.

Em uma área de aproximadamente dois hectares adjacente ao remanescente florestal foi introduzida a espécie Citrus latifolia Tanaka (limão Tahiti) em enxertia sob a espécie Citrus limonia L. Osbeck (limão Cravo), e no restante da área (aproximadamente $10 \mathrm{ha}$ ) foram introduzidas espécies de forrageiras exóticas, Urochloa decumbens (Stapf) Webster e Urochloa humidicola (Rendle) Morrone \& Zuloaga (antigo gênero Brachiaria) para a utilização desta área como pastagem (Anexo B e C). Estas áreas foram manejadas para produção, sendo que a área destinada ao cultivo do Citrus sp teve o seu subosque periodicamente limpo e a área destinada a pastagem foi frequentemente queimada e roçada.

A efetiva interdição dessas áreas foi realizada em 1992, estando, portanto, atualmente com 10 anos de abandono.

A área com citricultura apresenta-se atualmente em estágio inicial a intermediário de regeneração natural e com um dossel de aproximadamente $4 \mathrm{~m}$, com a predominância na regeneração de espécies da família Melastomataceae, destacando-se Leandra sp e Clidemia $s p$, no subosque, e Tibouchina sp, no dossel. Embora muitos limoeiros estejam no subosque, sombreados por regenerantes, estes ainda encontram-se produtivos (Anexo C).

Apesar da pastagem ter sido abandonada na mesma época que área com citricultura, não há, a princípio, sinais de regeneração natural condizente com o tempo de abandono. O que se verifica é uma cobertura vegetal constituída predominantemente pelas espécies inicialmente introduzidas e por espécies herbáceas, em especial ruderais invasoras de pastagens com alguns poucos arbustos esparsos: Psidium guajava, Psidium cattleianum, Rapanea ferruginea e Vernonia polyanthes. (Anexo B).

\subsubsection{Alocação das parcelas}

Foram instaladas três faixas de amostragem: duas na pastagem e uma no interior do cultivo de Citrus sp. Para a implementação de cada faixa, foi delimitada uma área de $3000 \mathrm{~m}^{2}$ 
(20 m de largura e $150 \mathrm{~m}$ de comprimento), onde foram demarcadas 15 parcelas de $10 \mathrm{X} 20$ m. No interior de cada faixa, foi realizada uma amostragem aleatória (IBGE, 1992), de cinco parcelas (Anexo D).

As parcelas instaladas na pastagem foram alocadas na distância de 0-20 m e 80-100 m do remanescente florestal. Já as parcelas instaladas no interior do cultivo de Citrus sp encontram-se aleatoriamente distribuídas em seu interior.

A instalação das sub-parcelas foi realizada com o auxílio de trena e bússola, sendo localizadas pelas coordenadas X e Y da parcela, considerando a coordenada X a largura da parcela $(10 \mathrm{~m})$ e $\mathrm{Y}$ o comprimento $(20 \mathrm{~m})$. As parcelas foram delimitadas com material permanente (canos de PVC preenchidos com cimento), permitindo reavaliações futuras. Para a amostragem deste trabalho, foi utilizado barbante para delimitar visualmente as parcelas.

No interior de cada parcela sorteada foram alocados três coletores de sementes para a avaliação da chuva de sementes (Anexo D).

\subsubsection{Avaliação da dispersão de sementes}

Para a avaliação da chuva de sementes foram distribuídos aleatoriamente em cada parcela três coletores de sementes, sendo 15 coletores por faixa, totalizando 45 coletores nas três faixas experimentais.

Foram utilizados coletores circulares plásticos que, por serem leves, eram de fácil transporte e alta durabilidade no campo. Estes possuíam uma abertura 0,52 $\mathrm{m}$ de diâmetro e uma área de coleta de $0,2123 \mathrm{~m}^{2}$ e uma profundidade de $0,40 \mathrm{~m}$, que permite maior acúmulo de sementes e serapilheira e dificulta a predação de sementes por pequenos mamíferos (Figura $1)$.

A área amostral total da chuva de sementes foi de $9,5535 \mathrm{~m}^{2}$.

$\mathrm{Na}$ abertura dos coletores foi fixado um tecido com o intuito de coletar sementes de todos os tamanhos, inclusive as de tamanho muito pequeno, e facilitar a remoção do material contido em seu interior. Este tecido tem a composição de $70 \%$ de poliéster e $30 \%$ de algodão 
(Figura 2). Esta composição foi escolhida porque não retém umidade por tempo prolongado, que poderia proporcionar o apodrecimento do material em seu interior (Grombone-Guaratini, 1999).

Mensalmente, durante o período de março/2001 até fevereiro/2002 os coletores tiveram o seu conteúdo recolhido, totalizando um ano de coleta. As datas das coletas foram $16 / 03,16 / 04,23 / 05,22 / 06,21 / 07,21 / 08,28 / 09,29 / 10,30 / 11,29 / 12$ de 2001, 29/01 e 28/02 de 2002.

O material coletado foi acondicionado em sacos de papel, rotulado e depois transportado ao laboratório, onde foi seco em temperatura ambiente. Após esse processo, o material foi triado separando-se manualmente as sementes da serapilheira.

Foram feitas observações e coletas mensais de material botânico de ervas, arbustos e árvores férteis presentes na área experimental e no remanescente florestal do entorno, com o intuito de facilitar e confirmar a identificação das sementes.

Em cada faixa experimental foram calculados a média e o desvio padrão das sementes depositadas nos coletores separados por forma de vida, além da densidade relativa e absoluta por espécie. Foi realizado o teste de análise de variância de Kruskal-Wallis (Zar, 1984), considerando apenas o número de indivíduos das espécies arbustivas-arbóreas, para testar se há diferenças significativas entre as três faixas experimentais.

\subsubsection{Identificação das sementes}

As sementes foram identificadas com auxílio de microscópio estereoscópico bilocular, a partir da comparação do material fértil coletado na área de estudo e pela consulta de bibliografia. As sementes encontradas foram quantificadas e identificadas até o nível de espécie, gênero ou família quando possível, ou separadas em morfo-espécies. 


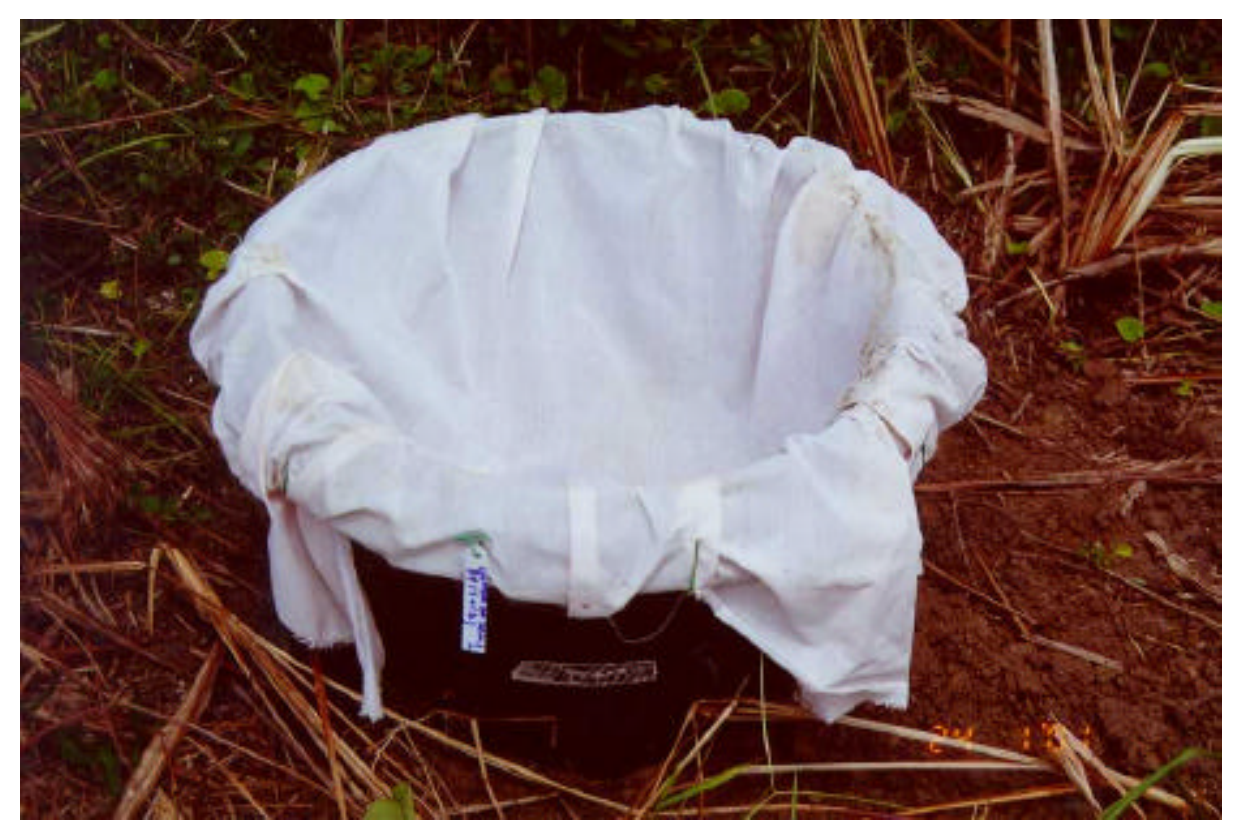

Figura 1 - Coletor de sementes instalado em campo para avaliar a chuva de sementes no interior do Parque Estadual do Jurupará, município de Ibiúna, São Paulo.

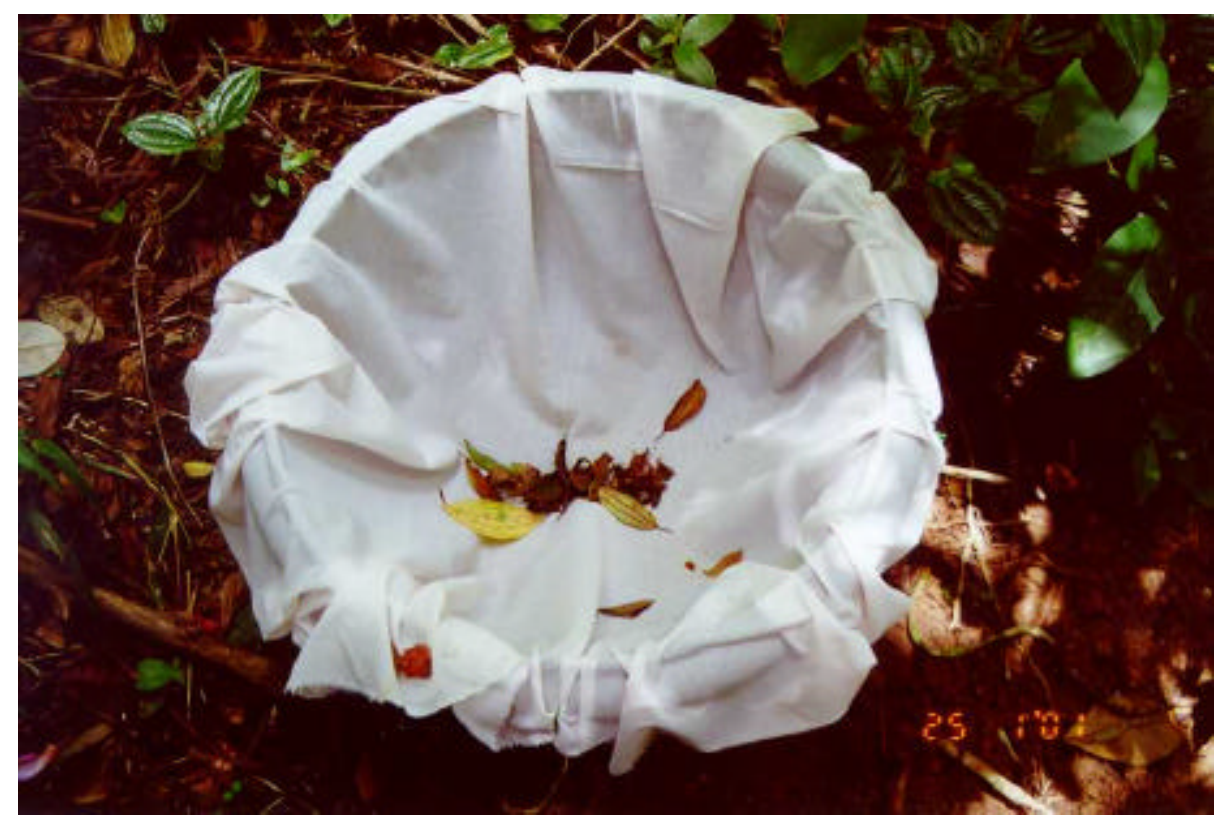

Figura 2 - Outro ângulo do coletor de sementes instalado em campo para avaliar a chuva de sementes, com material depositado, no interior do Parque Estadual do Jurupará, município de Ibiúna, São Paulo. 
Foi organizada uma sementoteca com as sementes provenientes da chuva de sementes, para facilitar identificações futuras deste projeto e de outros nessa área de conhecimento.

Foram incluídas na análise apenas as sementes aparentemente viáveis encontradas nos coletores (Foster, 1985). Frutos imaturos foram considerados abortados e descartados da contagem, por não serem efetivos no aumento do tamanho da população (Stephenson, 1981).

Para os frutos que possuíam muitas sementes de tamanho diminuto em seu interior, foi realizada uma média de contagem de sementes presentes em 10 frutos de cada espécie, para não haver a necessidade de abrir todos os frutos encontrados com estas características. Este recurso foi utilizado para duas espécies encontradas: Tibouchina sp. e Leandra sp. A determinação da síndrome de dispersão foi realizada, quando possível, mediante consulta a bibliografia pertinente e observações em campo.

\section{Resultados}

Durante o período de março de 2001 a fevereiro de 2002 foram depositados nos coletores de sementes 125.214 sementes, pertencentes a 99 espécies. A densidade absoluta de deposição de sementes foi de 13.108,67 sem.m².

Na faixa experimental no interior do cultivo de Citrus sp foram depositadas 106.811 sementes, pertencentes a 57 espécies (Tabela 1). A densidade absoluta encontrada foi de 33.546,17 sem. $\mathrm{m}^{-2}$. As espécies mais frequentes foram Leandra sp. $(61,65 \%)$ e Tibouchina sp $(35,49 \%)$.

$\mathrm{Na}$ pastagem de $0-20 \mathrm{~m}$ de distância do remanescente florestal, foram depositadas 8.636 sementes, pertencentes a 51 espécies (Tabela 2). A densidade absoluta encontrada foi de $2.712,31$ sem. $\mathrm{m}^{-2}$. As espécies mais frequentes foram Urochloa decumbens $(60,16 \%)$, e Vernonia polyanthes $(9,30 \%)$.

No interior da pastagem de 80-100m de distância do remanescente florestal foram depositadas 9.767 sementes, pertencentes a 52 espécies (Tabela 3). A densidade absoluta 
encontrada foi de $3.067,53 \mathrm{sem} . \mathrm{m}^{-2}$. As espécies mais frequentes foram Vernonia polyanthes Less. (17,93\%), e Paspalum conspersum Schrad. (16,35\%).

Os valores médios e desvios padrões das sementes depositadas nos coletores e separadas por forma de vida em cada faixa experimental são apresentados na Tabela 4. Considerando todas as formas de vida das sementes depositadas nos coletores, a síndrome de dispersão anemocórica foi a mais representativa nas faixas experimentais na pastagem $(94,43 \%$ e 79,72\%, para as faixas experimentais localizadas a $020 \mathrm{~m}$ e $80-100 \mathrm{~m}$ de distância do remanescente florestal, respectivamente). A síndrome de dispersão zoocórica foi a mais representativa na faixa experimental no interior do cultivo de Citrus sp (61,79\%) (Tabela 5).

Tabela 4. Média e desvio padrão do número de sementes depositadas nos coletores de sementes em cada faixa experimental, separados por forma de vida, no interior do Parque Estadual do Jurupará, município de Ibiúna, São Paulo.

\begin{tabular}{lcccc}
\hline & \multicolumn{4}{c}{ Número de sementes por forma de vida } \\
\multicolumn{1}{c}{ Faixas } & Árvore & Arbusto & Erva & Indeterminada \\
\hline Citrus sp & $2.683,27 \pm 1.595,43$ & $4.387,60 \pm 3.709,52$ & $25,47 \pm 12,78$ & $24,40 \pm 12,63$ \\
& & & & \\
$\begin{array}{l}\text { Pastagem } \\
\text { 0-20 m }\end{array}$ & $54,87 \pm 49,19$ & $11,47 \pm 19,49$ & $429,07 \pm 171,11$ & $80,33 \pm 89,74$ \\
$\begin{array}{l}\text { Pastagem } \\
80-100 \mathrm{~m}\end{array}$ & $85,07 \pm 87,92$ & $1,00 \pm 1,60$ & $442,40 \pm 85,55$ & $122,67 \pm 105,73$ \\
\hline
\end{tabular}


Tabela 5. Síndrome de dispersão com o número de sementes totais e densidade absoluta das sementes depositadas nos coletores de sementes na área experimental no interior do Parque Estadual do Jurupará, município de Ibiúna, São Paulo. $\mathrm{N}^{\circ}=$ número total de sementes coletadas, $\mathrm{DA}=$ densidade absoluta.

\section{Síndrome de dispersão}

\begin{tabular}{lcccccc}
\multicolumn{1}{c}{ Faixas amostrais } & \multicolumn{2}{c}{ Anemocórica } & \multicolumn{2}{c}{ Zoocóricas } & \multicolumn{2}{c}{ Indeterminada } \\
& $\mathrm{N}^{\circ}$ & $\begin{array}{c}\mathrm{DA} \\
\left(\mathrm{sem} \cdot \mathrm{m}^{-2}\right)\end{array}$ & $\mathrm{N}^{\circ}$ & $\begin{array}{c}\mathrm{DA} \\
\left(\mathrm{sem}_{\mathrm{m}}{ }^{-2}\right)\end{array}$ & $\mathrm{N}^{\circ}$ & $\begin{array}{c}\mathrm{DA} \\
\left(\mathrm{sem} \cdot \mathrm{m}^{-2}\right)\end{array}$ \\
\hline Citrus $\mathrm{sp}$ & 40.681 & $12.776,70$ & 66.007 & $20.730,84$ & 123 & 38,63 \\
Pastagem $(0-20 \mathrm{~m})$ & 8.155 & $2.561,24$ & 200 & 62,81 & 281 & 88,25 \\
Pastagem $(80-100 \mathrm{~m})$ & 7.787 & $2.445,67$ & 609 & 191,27 & 1371 & 430,59 \\
\hline
\end{tabular}

O número total de sementes agrupadas por forma de vida nas três faixas experimentais é ilustrado na Figura 3, deixando evidente que na faixa experimental no interior do cultivo de Citrus sp o número total de sementes depositadas é proximadamente 10 vezes maior do que nas faixas experimentais no interior da pastagem. $\mathrm{Na}$ área de Citrus sp, as espécies arbóreas foram predominantes no primeiro mês de coleta (março - 74,57\%), seguido por dois meses (abril - 87,11\% e maio - 87,37\%) de predominância de espécies arbustivas. No entanto, em setembro (10,34\% - arbóreas, 46,90\% - arbustivas) e outubro (18,77\% - arbóreas, 4,98\% arbustivas) a densidade das espécies arbustivas-arbóreas reduziu muito, sendo substituídas por espécies herbáceas em setembro (40\%) e outubro (73,56\%) (Figura 4 A). Na pastagem foi observada uma situação inversa, nas duas faixas experimentais houve um pico de deposição de espécies arbóreas em outubro (89,11\% e 89,07\%), concomitante com a diminuição de espécies herbáceas $(10,13 \%$ e 10,93\%) para a distância de 0-20 m e 80-100m do remanescente florestal, respectivamente (Figuras 3 B, 3 C, 4 B, 4 C).

A análise temporal da síndrome de dispersão das sementes na área de Citrus $s p$ revelou que as espécies anemocóricas e zoocóricas se intercalaram no período analizado (Figua 5 A). Na pastagem predominaram espécies anemocóricas, sendo observadas na faixa 
mais próxima do remanescente florestal (0-20m) durante todo o período analisado e principalmente em junho para a faixa mais distante (80-100m).

Uma comparação entre sementes dos gêneros arbustivos-arbóreas depositadas nos coletores e amostradas nos levantamentos florísticos realizados na mesma formação florestal e próximo ao local de estudo é apresentada na Tabela 6.

Tabela 6. Comparação entre os genêros arbustivos-arbóreas depositados nos coletores de sementes instalados no interior do Parque Estadual do Jurupará, Ibiúna, São Paulo com levantamentos florísticos realizados sobre a mesma formação florestal no estado de São Paulo.

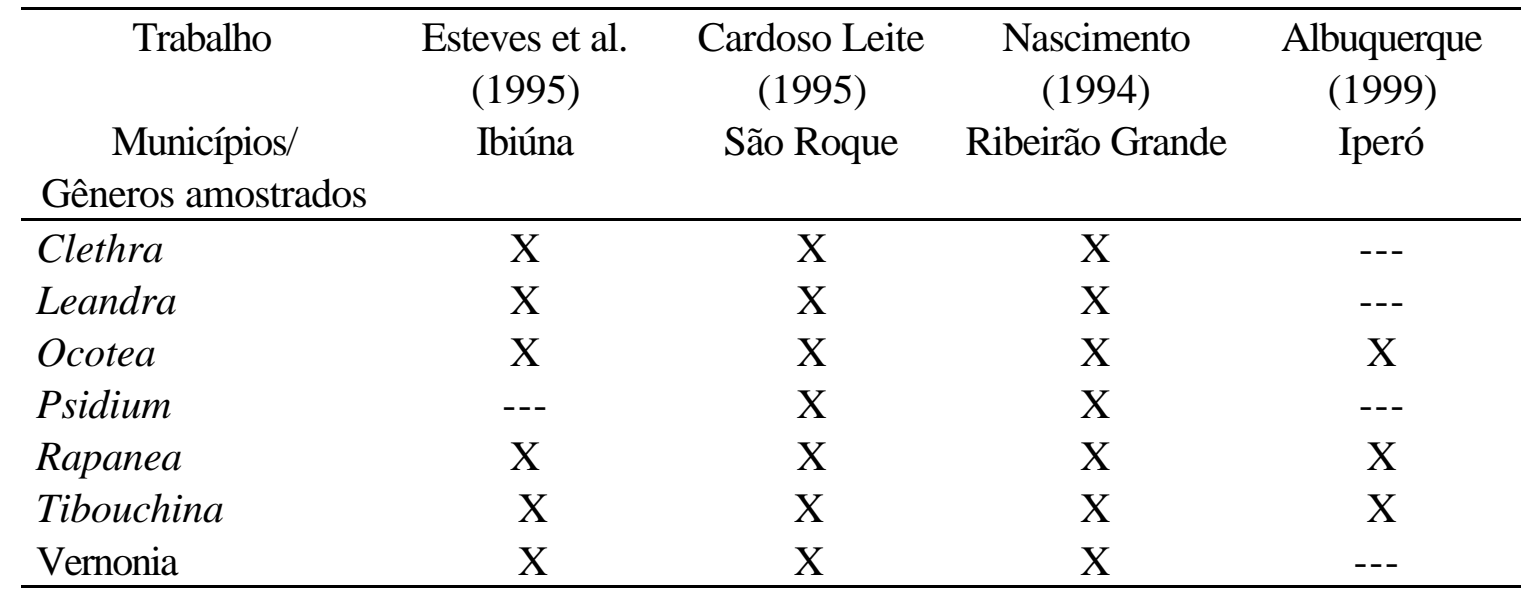

No teste de análise de variância (Kruskal-Wallis) realizado, foram encontradas diferenças significativas entre o número de sementes de espécies arbustivas-arbóreas depositadas na faixa experimental no interior do cultivo de Citrus $s p$ e as faixas experimentais no interior da pastagem $\left(\chi^{2}=9,42, p=0,0090\right)$. No entanto, não foram encontradas diferenças significativas entre as duas faixas experimentais na pastagem, localizadas a $0-20 \mathrm{~m}$ e 80-100m de distância do remanescente florestal (Figura 6). 


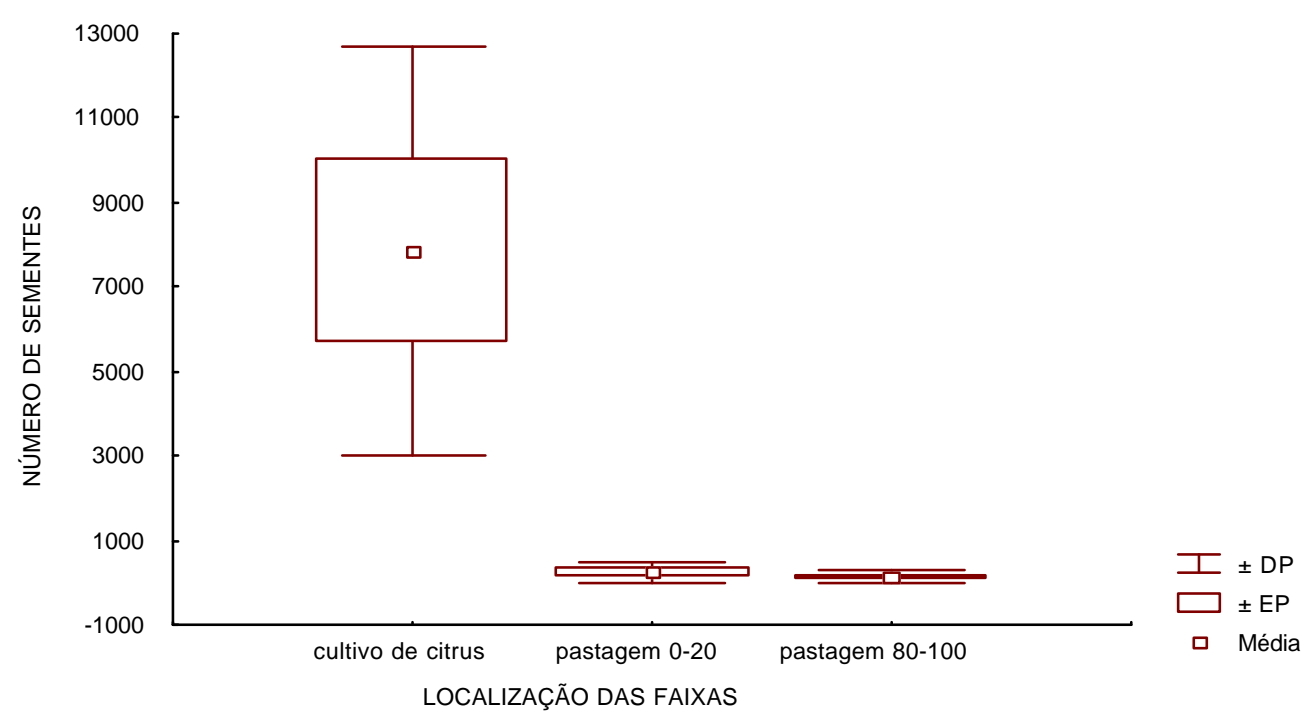

Figura 6 - "Boxplot" do número de sementes de espécies arbustivo-arbóreas depositadas nos coletores de sementes na área de Citrus sp, na pastagem à 0-20 m e 80-100 m de distância do remanescente florestal no interior do Parque Estadual do Jurupará, município de Ibiúna, São Paulo. 
Tabela 1. Número de sementes, densidade absoluta, densidade relativa, forma de vida e síndrome de dispersão das espécies depositadas nos coletores de sementes na faixa experimental na área Citrus sp, no interior do Parque Estadual do Jurupará, município de Ibiúna, São Paulo. DA = densidade absoluta, $\mathrm{DR}=$ densidade relativa, anem = anemocórica, arb = arbustivo, arv = arbóreo, herb = herbáceo, indet = indeterminada, $z 00=$ zoocórica .

\begin{tabular}{|c|c|c|c|c|c|}
\hline Espécies & $\begin{array}{c}\mathrm{N}^{\circ} \mathrm{de} \\
\text { semente } \\
\mathrm{s}\end{array}$ & $\begin{array}{c}\mathrm{DA} \\
\left(\mathrm{sem} \cdot \mathrm{m}^{-2}\right)\end{array}$ & $\begin{array}{l}\text { DR } \\
(\%)\end{array}$ & $\begin{array}{c}\text { Forma de } \\
\text { vida }\end{array}$ & $\begin{array}{c}\text { Síndrome } \\
\text { de } \\
\text { dispersão }\end{array}$ \\
\hline Tibouchina sp. & 37910 & 11906,41 & 35,490 & $\operatorname{arv}$ & anem \\
\hline Vernonia polyanthes Less. & 2366 & 743,09 & 2,215 & $\operatorname{arv}$ & anem \\
\hline Rapanea ferruginea (Ruiz et Pav.) Mez. & 78 & 24,50 & 0,073 & arv & zoo \\
\hline Sapindaceae 1 & 12 & 3,77 & 0,011 & arv & anem \\
\hline Clethra scabra Pers. & 10 & 3,14 & 0,009 & $\operatorname{arv}$ & anem \\
\hline Ocotea sp & 3 & 0,94 & 0,003 & $\operatorname{arv}$ & zoo \\
\hline Leandra sp & 65.857 & 20683,73 & 61,653 & arb & zoo \\
\hline Eupatorium sp & 258 & 81,03 & 0,242 & herb & anem \\
\hline Solanum sp & 67 & 21,04 & 0,063 & herb & zoo \\
\hline Hybanthus sp & 18 & 5,65 & 0,017 & herb & indet \\
\hline Cyperus sp4 & 11 & 3,45 & 0,010 & herb & anem \\
\hline Andropogon bicornis $\mathrm{L}$. & 8 & 2,51 & 0,007 & herb & anem \\
\hline Desmodium adscendens (SW.) DC. & 4 & 1,26 & 0,004 & herb & zoo \\
\hline Urochloa decumbens (Stapf) Webster & 4 & 1,26 & 0,004 & herb & zoo/anem \\
\hline Melilotus indica All. & 3 & 0,94 & 0,003 & herb & indet \\
\hline Elephantopus mollis H.B.K. & 1 & 0,31 & 0,001 & herb & anem \\
\hline Urochloa sp & 1 & 0,31 & 0,001 & herb & zoo/anem \\
\hline Cyperus sp 5 & 1 & 0,31 & 0,001 & herb & anem \\
\hline Poaceae 10 & 1 & 0,31 & 0,001 & herb & anem \\
\hline Paspalum sp & 1 & 0,31 & 0,001 & herb & anem \\
\hline Morfo espécie 58 & 37 & 11,42 & 0,035 & indet & indet \\
\hline Asteraceae 3 & 41 & 12,88 & 0,038 & indet & anem \\
\hline Asteraceae 13 & 22 & 6,91 & 0,021 & indet & anem \\
\hline Asteraceae 11 & 12 & 3,77 & 0,011 & indet & anem \\
\hline Morfo espécie 18 & 12 & 3,77 & 0,011 & indet & indet \\
\hline Morfo espécie 57 & 10 & 3,14 & 0,009 & indet & indet \\
\hline Asteraceae 1 & 9 & 2,83 & 0,008 & indet & anem \\
\hline Morfo espécie 22 & 7 & 2,20 & 0,007 & indet & indet \\
\hline Morfo espécie 59 & 4 & 1,26 & 0,004 & indet & indet \\
\hline Asteraceae 14 & 3 & 0,94 & 0,003 & 3 indet & anem \\
\hline Asteraceae 2 & 3 & 0,94 & 0,003 & 3 indet & anem \\
\hline
\end{tabular}


Tabela 1. Número de sementes, densidade absoluta, densidade relativa, forma de vida e síndrome de dispersão das espécies depositadas nos coletores de sementes na área de Citrus $s p$, no interior do Parque Estadual do Jurupará, município de Ibiúna, São Paulo. DA = densidade absoluta, $\mathrm{DR}=$ densidade relativa, anem $=$ anemocórica, arb $=$ arbustivo, arv $=$ arbóreo, herb = herbáceo, indet = indeterminada, $z 00=$ zoocórica.

\begin{tabular}{|c|c|c|c|c|c|}
\hline Espécies & $\begin{array}{c}\mathrm{N}^{\circ} \mathrm{de} \\
\text { sementes }\end{array}$ & $\begin{array}{c}\text { DA } \\
\left(\text { sem.m }{ }^{-2}\right)\end{array}$ & $\begin{array}{l}\text { DR } \\
(\%)\end{array}$ & $\begin{array}{l}\text { Forma de } \\
\text { vida }\end{array}$ & $\begin{array}{c}\text { Síndrome } \\
\text { de } \\
\text { dispersão }\end{array}$ \\
\hline Morfo espécie 28 & 3 & 0,94 & 0,003 & indet & indet \\
\hline Asteraceae 4 & 2 & 0,63 & 0,002 & indet & anem \\
\hline Morfo espécie 11 & 2 & 0,63 & 0,002 & indet & indet. \\
\hline Morfo espécie 20 & 2 & 0,63 & 0,002 & indet & indet \\
\hline Morfo espécie 30 & 2 & 0,63 & 0,002 & indet & indet \\
\hline Morfo espécie 40 & 2 & 0,63 & 0,002 & indet & indet \\
\hline Morfo espécie 44 & 2 & 0,63 & 0,002 & indet & indet \\
\hline Asteraceae 16 & 2 & 0,63 & 0,002 & indet & anem \\
\hline Morfo espécie 50 & 2 & 0,63 & 0,002 & indet & indet \\
\hline Morfo espécie 47 & 2 & 0,63 & 0,002 & indet & indet \\
\hline Morfo espécie 10 & 1 & 0,31 & 0,001 & indet & indet \\
\hline Morfo espécie 21 & 1 & 0,31 & 0,001 & indet & indet \\
\hline Morfo espécie 26 & 1 & 0,31 & 0,001 & indet & indet \\
\hline Morfo espécie 27 & 1 & 0,31 & 0,001 & indet & indet \\
\hline Morfo espécie 31 & 1 & 0,31 & 0,001 & indet & indet \\
\hline Morfo espécie 32 & 1 & 0,31 & 0,001 & indet & indet \\
\hline Morfo espécie 37 & 1 & 0,31 & 0,001 & indet & indet \\
\hline Asteraceae 6 & 1 & 0,31 & 0,001 & indet & anem \\
\hline Morfo espécie 46 & 1 & 0,31 & 0,001 & indet & indet \\
\hline Asteraceae 15 & 1 & 0,31 & 0,001 & indet & anem \\
\hline Morfo espécie 48 & 1 & 0,31 & 0,001 & indet & indet \\
\hline Morfo espécie 49 & 1 & 0,31 & 0,001 & indet & indet \\
\hline Morfo espécie 51 & 1 & 0,31 & 0,001 & indet & indet \\
\hline Morfo espécie 56 & 1 & 0,31 & 0,001 & indet & indet \\
\hline Morfo espécie 60 & 1 & 0,31 & 0,001 & indet & indet \\
\hline Mimosaceae 1 & 1 & 0,31 & 0,001 & indet & indet \\
\hline TOTAL & 106.811 & $33.546,17$ & 100,00 & ---- & ---- \\
\hline
\end{tabular}


Tabela 2. Número de sementes, densidade absoluta, densidade relativa, forma de vida e síndrome de dispersão das espécies depositadas nos coletores de sementes na faixa experimental na pastagem de $020 \mathrm{~m}$ de distância do remanescente florestal no interior do Parque Estadual do Jurupará, município de Ibiúna, São Paulo. DA = densidade absoluta, DR = densidade relativa, anem = anemocórica, arb = arbustivo, arv = arbóreo, herb = herbáceo, indet $=$ indeterminada, zoo = zoocórica .

\begin{tabular}{|c|c|c|c|c|c|}
\hline Espécies & $\begin{array}{c}\mathrm{N}^{\circ} \mathrm{de} \\
\text { sementes }\end{array}$ & $\begin{array}{c}\text { DA } \\
\left(\mathrm{sem} \cdot \mathrm{m}^{-2}\right)\end{array}$ & $\begin{array}{l}\mathrm{DR} \\
(\%)\end{array}$ & $\begin{array}{l}\text { Forma de } \\
\text { vida }\end{array}$ & $\begin{array}{c}\text { Síndrome } \\
\text { de } \\
\text { dispersão }\end{array}$ \\
\hline Vernonia polyanthes Less. & 800 & 251,26 & 9,30 & $\operatorname{arv}$ & anem \\
\hline Tibouchina sp & 100 & 31,41 & 1,16 & arv & anem \\
\hline Clethra scabra Pers. & 35 & 10,99 & 0,41 & $\operatorname{arv}$ & anem \\
\hline Leandra sp & 129 & 40,52 & 1,50 & arb & zoo \\
\hline Psidium $\mathrm{sp}$ & 5 & 1,57 & 0,06 & arb & zoO \\
\hline Urochloa decumbens (Stapf) Webster & 5.174 & $1.625,00$ & 60,16 & herb & zoo/anem \\
\hline Andropogon bicornis $\mathrm{L}$. & 412 & 129,40 & 4,79 & herb & anem \\
\hline Eupatorium sp & 383 & 120,29 & 4,45 & herb & anem \\
\hline Panicum sp2 & 168 & 52,76 & 1,95 & herb & anem \\
\hline Cyperus esculentus L. & 138 & 43,34 & 1,60 & herb & anem \\
\hline Hybanthus sp & 105 & 32,98 & 1,22 & herb & indet \\
\hline Desmodium adscendens (SW.) DC. & 39 & 12,25 & 0,45 & herb & zoo \\
\hline Melilotus indica All. & 39 & 12,25 & 0,45 & herb & indet \\
\hline Poaceae 8 & 32 & 10,05 & 0,37 & herb & anem \\
\hline Elephantopus mollis H.B.K. & 23 & 7,22 & 0,27 & herb & anem \\
\hline Paspalum conspersum Schrad. & 17 & 5,34 & 0,20 & herb & anem \\
\hline Solanum sp & 14 & 4,40 & 0,16 & herb & zoo \\
\hline Cyperus sp4 & 10 & 3,14 & 0,12 & herb & anem \\
\hline Scleria pterota Presl & 12 & 3,77 & 0,14 & herb & zoo \\
\hline Panicum sp 1 & 9 & 2,83 & 0,10 & herb & anem \\
\hline Poaceae 11 & 5 & 1,57 & 0,06 & herb & anem \\
\hline Sida rhombifolia L. & 5 & 1,57 & 0,06 & herb & zoo \\
\hline Poaceae 9 & 2 & 0,63 & 0,02 & herb & anem \\
\hline Poaceae 2 & 2 & 0,63 & 0,02 & herb & anem \\
\hline Cyperus sp 1 & 1 & 0,31 & 0,01 & herb & anem \\
\hline Cyperus sp2 & 1 & 0,31 & 0,01 & herb & anem \\
\hline Asteraceae 13 & 415 & 130,34 & 4,83 & indet & anem \\
\hline Asteraceae 2 & 225 & 70,67 & 2,62 & indet & anem \\
\hline Asteraceae 3 & 101 & 31,72 & 1,17 & indet & anem \\
\hline
\end{tabular}


Tabela 2. Número de sementes, densidade absoluta, densidade relativa, forma de vida e síndrome de dispersão das espécies depositadas nos coletores de sementes na faixa experimental na pastagem de $020 \mathrm{~m}$ de distância do remanescente florestal no interior do Parque Estadual do Jurupará, município de Ibiúna, São Paulo. DA = densidade absoluta, DR = densidade relativa, anem = anemocórica, arb = arbustivo, arv = arbóreo, herb = herbáceo, indet $=$ indeterminada, zoo = zoocórica .

\begin{tabular}{lrrrcc}
\hline \multicolumn{1}{c}{ Espécies } & $\begin{array}{c}\mathrm{N}^{\circ} \text { de } \\
\text { sementes }\end{array}$ & $\begin{array}{c}\text { DA } \\
\left(\mathrm{sem}^{-2}\right)\end{array}$ & $\begin{array}{c}\text { DR } \\
(\%)\end{array}$ & $\begin{array}{c}\text { Forma de } \\
\text { vida }\end{array}$ & $\begin{array}{c}\text { Síndrome } \\
\text { de } \\
\text { dispersão }\end{array}$ \\
\hline Asteraceae 8 & & & & & anem \\
Asteraceae 18 & 28 & 29,84 & 1,10 & indet & anem \\
Morfo espécie 23 & 15 & 4,71 & 0,17 & indet & indet \\
Morfo espécie 44 & 12 & 3,77 & 0,14 & indet & indet \\
Morfo espécie 30 & 12 & 3,77 & 0,14 & indet & indet \\
Asteraceae13 & 11 & 3,45 & 0,13 & indet & anem \\
Morfo espécie 53 & 7 & 2,20 & 0,08 & indet & indet \\
Morfo espécie 61 & 8 & 2,51 & 0,09 & indet & indet \\
Asteraceae 1 & 8 & 2,51 & 0,09 & indet & anem \\
Asteraceae 15 & 6 & 1,88 & 0,07 & indet & anem \\
Morfo espécie 3 & 5 & 1,57 & 0,06 & indet & indet \\
Asteraceae 7 & 5 & 1,57 & 0,06 & indet & anem \\
Morfo espécie 12 & 5 & 1,57 & 0,06 & indet & indet \\
Morfo espécie 2 & 5 & 1,57 & 0,06 & indet & indet \\
Morfo espécie 54 & 3 & 0,94 & 0,03 & indet & indet \\
Asteraceae 4 & 2 & 0,63 & 0,02 & indet & anem \\
Asteraceae 6 & 2 & 0,63 & 0,02 & indet & anem \\
Morfo espécie 32 & 2 & 0,63 & 0,02 & indet & indet \\
Asteraceae 11 & 1 & 0,31 & 0,01 & indet & anem \\
Morfo espécie 17 & 1 & 0,31 & 0,01 & indet & indet \\
Asteraceae 17 & 1 & 0,31 & 0,01 & indet & anem \\
Morfo espécie 6 & 0,31 & 0,01 & indet & indet \\
TOTAL & $2.712,31$ & 100,00 & --- & --- \\
\hline
\end{tabular}


Tabela 3. Número de sementes, densidade absoluta, densidade relativa, forma de vida e síndrome de dispersão das espécies depositadas nos coletores de sementes na faixa experimental na pastagem de 80-100 m de distância do remanescente florestal no interior do Parque Estadual do Jurupará, município de Ibiúna, São Paulo. DA = densidade absoluta, DR = densidade relativa, anem = anemocórica, arb = arbustivo, arv = arbóreo, herb = herbáceo, indet $=$ indeterminada, zoo = zoocórica .

\begin{tabular}{|c|c|c|c|c|c|}
\hline Espécies & $\begin{array}{c}\mathrm{N}^{\circ} \mathrm{de} \\
\text { sementes }\end{array}$ & $\begin{array}{c}\mathrm{DA} \\
\left(\mathrm{sem} \cdot \mathrm{m}^{-2}\right)\end{array}$ & $\begin{array}{l}\text { DR } \\
(\%)\end{array}$ & $\begin{array}{c}\text { Forma de } \\
\text { vida }\end{array}$ & $\begin{array}{c}\text { Síndrome } \\
\text { de } \\
\text { dispersão }\end{array}$ \\
\hline Vernonia polyanthes Less. & 1.788 & 561,56 & 17,93 & arv & anem \\
\hline Clethra scabra Pers. & 23 & 7,22 & 0,23 & arv & anem \\
\hline Tibouchina sp & 12 & 3,77 & 0,12 & arv & anem \\
\hline Leandra sp & 16 & 5,03 & 0,16 & arb & zoo \\
\hline Paspalum conspersum Schrad. & 1.631 & 512,25 & 16,35 & herb & anem \\
\hline Andropogon bicornis L. & 1.479 & 464,51 & 14,83 & herb & anem \\
\hline Urochloa sp & 623 & 195,67 & 6,25 & herb & zoo/anem \\
\hline Panicum sp1 & 590 & 185,30 & 5,92 & herb & anem \\
\hline Sida rhombifolia $\mathrm{L}$. & 511 & 160,49 & 5,12 & herb & zoo \\
\hline Poaceae 4 & 408 & 128,14 & 4,09 & herb & anem \\
\hline Panicum sp3 & 248 & 77,89 & 2,49 & herb & anem \\
\hline Scleria pterota Presl & 180 & 56,53 & 1,80 & herb & anem \\
\hline Urochloa decumbens (Stapf) Webster & 245 & 76,95 & 2,46 & herb & zoo/anem \\
\hline Paspalum sp & 197 & 61,87 & 1,98 & herb & anem \\
\hline Desmodium adscendens (SW.) DC. & 85 & 26,70 & 0,85 & herb & zoo \\
\hline Poaceae 2 & 41 & 12,88 & 0,41 & herb & anem \\
\hline Cyperus sp2 & 34 & 10,68 & 0,34 & herb & anem \\
\hline Cyperus sp3 & 31 & 9,74 & 0,31 & herb & anem \\
\hline Eupatorium sp & 31 & 9,74 & 0,31 & herb & anem \\
\hline Panicum sp2 & 28 & 8,79 & 0,28 & herb & anem \\
\hline Poaceae 6 & 27 & 8,48 & 0,27 & herb & anem \\
\hline Hybanthus sp & 13 & 4,08 & 0,13 & herb & indet \\
\hline Cyperus esculentus L. & 10 & 3,14 & 0,10 & herb & anem \\
\hline Cyperus sp 1 & 26 & 8,17 & 0,26 & herb & anem \\
\hline Melilotus indica All. & 16 & 5,03 & 0,16 & herb & indet \\
\hline Poaceae 9 & 12 & 3,77 & 0,12 & herb & anem \\
\hline Panicum sp1 & 6 & 1,88 & 0,06 & herb & anem \\
\hline Poaceae 10 & 6 & 1,88 & 0,06 & herb & anem \\
\hline Poaceae 5 & 3 & 0,94 & 0,03 & herb & anem \\
\hline
\end{tabular}


Tabela 3. Número de sementes, densidade absoluta, densidade relativa, forma de vida e síndrome de dispersão das espécies depositadas nos coletores de sementes na faixa experimental na pastagem de 80-100 m de distância do remanescente florestal no interior do Parque Estadual do Jurupará, município de Ibiúna, São Paulo. DA = densidade absoluta, DR = densidade relativa, anem $=$ anemocórica, arb = arbustivo, arv = arbóreo, herb = herbáceo, indet $=$ indeterminada, zoo = zoocórica .

\begin{tabular}{|c|c|c|c|c|c|}
\hline Espécies & $\begin{array}{c}\mathrm{N}^{\circ} \mathrm{de} \\
\text { sementes }\end{array}$ & $\begin{array}{c}\text { DA } \\
\left(\text { sem.m }{ }^{-2}\right)\end{array}$ & $\begin{array}{l}\mathrm{DR} \\
(\%)\end{array}$ & $\begin{array}{c}\text { Forma de } \\
\text { vida }\end{array}$ & $\begin{array}{c}\text { Síndrome } \\
\text { de } \\
\text { dispersão }\end{array}$ \\
\hline Elephantopus mollis H.B.K. & 2 & 0,63 & 0,02 & herb & anem \\
\hline Morfo espécie 3 & 794 & 249,37 & 7,96 & indet & indet \\
\hline Asteraceae 10 & 213 & 66,90 & 2,14 & indet & anem \\
\hline Asteraceae 3 & 143 & 44,91 & 1,43 & indet & anem \\
\hline Morfo espécie 15 & 62 & 19,47 & 0,62 & indet & indet \\
\hline Asteraceae 1 & 42 & 13,19 & 0,42 & indet & anem \\
\hline Asteraceae 2 & 35 & 10,99 & 0,35 & indet & anem \\
\hline Morfo espécie 34 & 27 & 8,48 & 0,27 & indet & indet \\
\hline Morfo espécie 54 & 26 & 8,17 & 0,26 & indet & indet \\
\hline Malpighiaceae 1 & 25 & 7,85 & 0,25 & indet & indet \\
\hline Morfo espécie 1 & 19 & 5,97 & 0,19 & indet & indet \\
\hline Morfo espécie 11 & 18 & 5,65 & 0,18 & indet & indet \\
\hline Asteraceae 9 & 13 & 4,08 & 0,13 & indet & anem \\
\hline Asteraceae 11 & 7 & 2,20 & 0,07 & indet & anem \\
\hline Morfo espécie 63 & 5 & 1,57 & 0,05 & indet & indet \\
\hline Morfo espécie 23 & 4 & 1,26 & 0,04 & indet & indet \\
\hline Morfo espécie 62 & 3 & 0,94 & 0,03 & indet & indet \\
\hline Morfo espécie 2 & 3 & 0,94 & 0,03 & indet & indet \\
\hline Morfo espécie 17 & 2 & 0,63 & 0,02 & indet & indet \\
\hline Morfo espécie 12 & 1 & 0,31 & 0,01 & indet & indet \\
\hline Morfo espécie 14 & 1 & 0,31 & 0,01 & indet & indet \\
\hline Morfo espécie 22 & 1 & 0,31 & 0,01 & indet & indet \\
\hline Morfo espécie 40 & 1 & 0,31 & 0,01 & indet & indet \\
\hline TOTAL & 9.767 & $3.067,53$ & 100,00 & --- & --- \\
\hline
\end{tabular}




\section{Citrus sp}

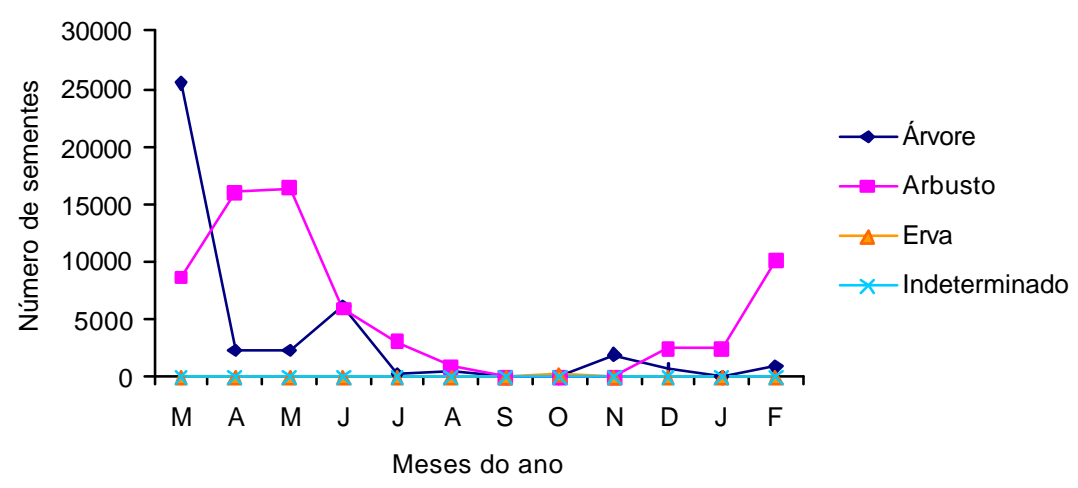

Pastagem de 0-20 m

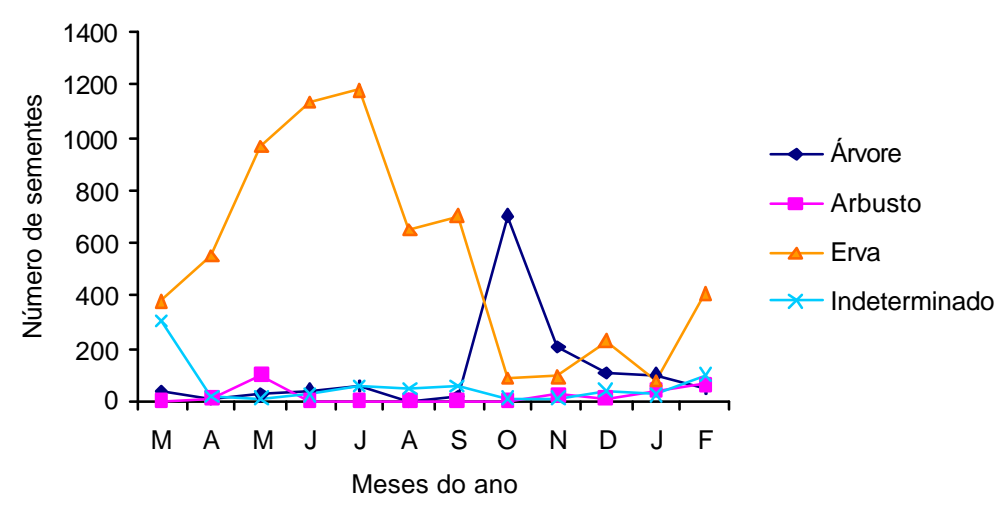

Pastagem de 80-100 m

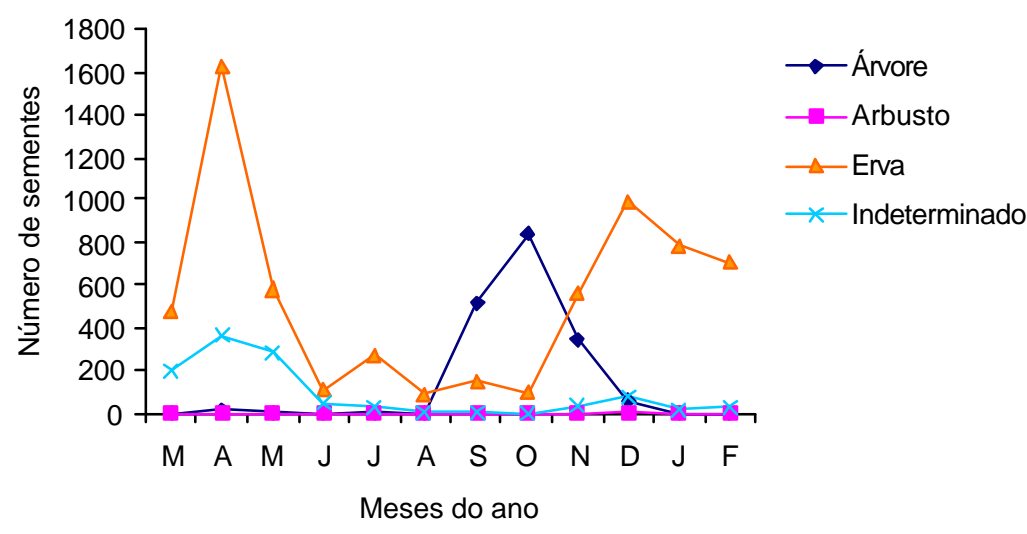

Figura 3 - Número total de sementes encontradas mensalmente nos coletores durante o período de março de 2001 a fevereiro de 2002, no interior da área de Citrus sp, pastagem de 0-20 m e 80-100 m de distância do reamnescente florestal, no Parque Estadual do Jurupurá, Ibiúna, São Paulo. 


\section{Citrus sp}

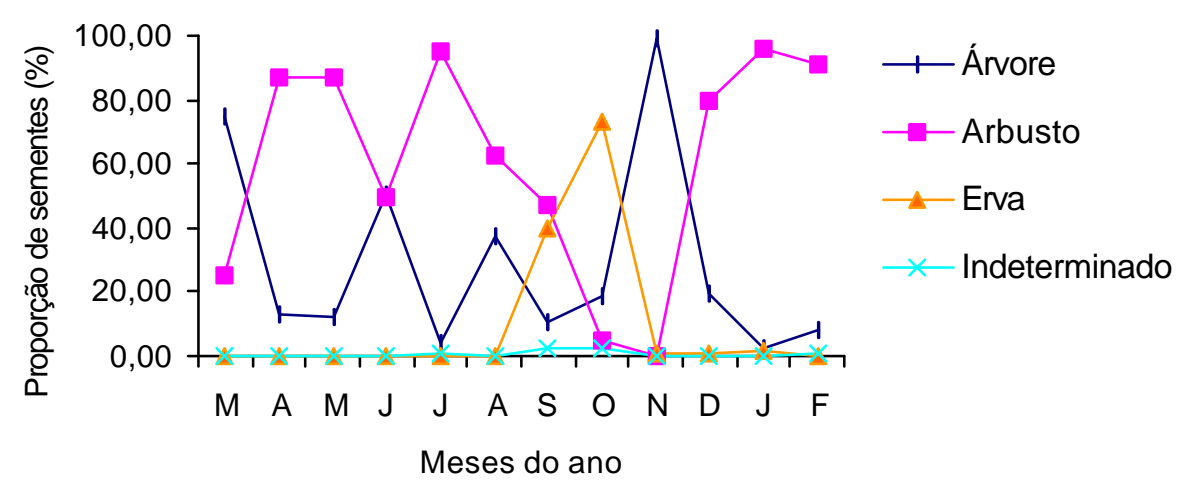

Pastagem de 0-20 m

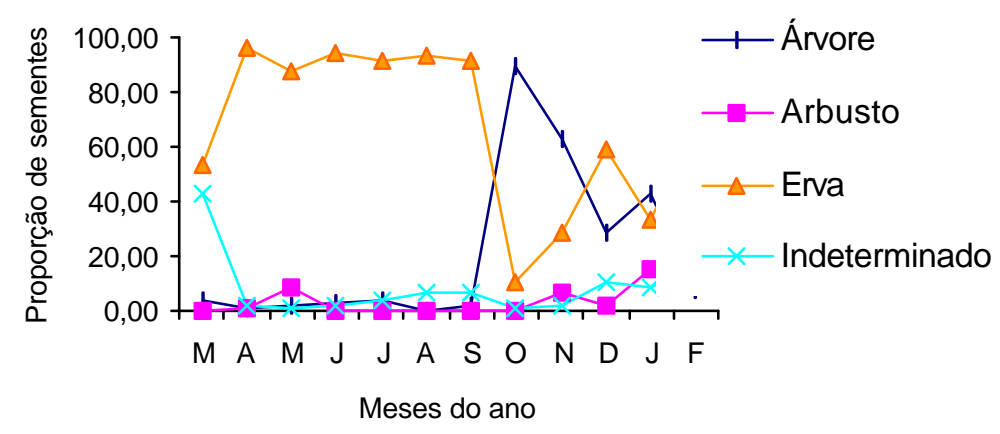

\section{Pastagem de 80-100 m}

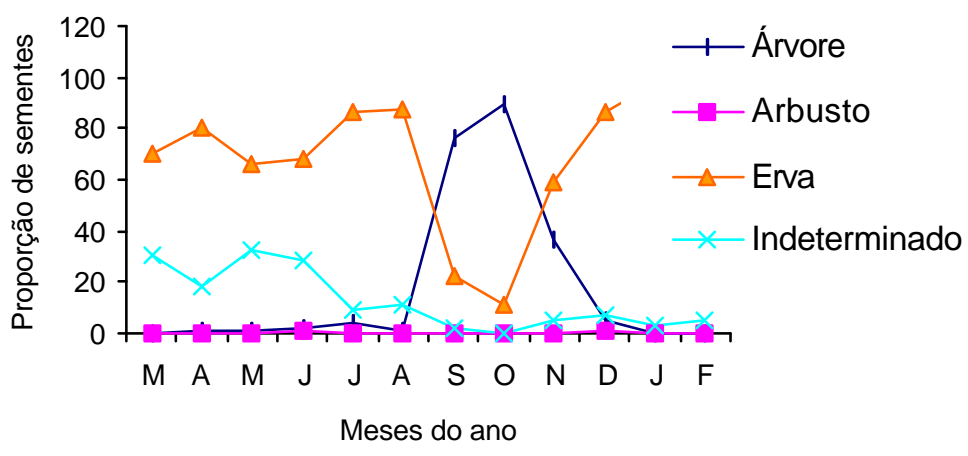

Figura 4 - Porcentagem de sementes encontradas mensalmente nos coletores durante o período de março de 2001 a fevereiro de 2002, no interior da área de Citrus sp, pastagem de 0-20 m e 80-100 m de distância do reamnescente florestal, no Parque Estadual do Jurupurá, Ibiúna, São Paulo. 

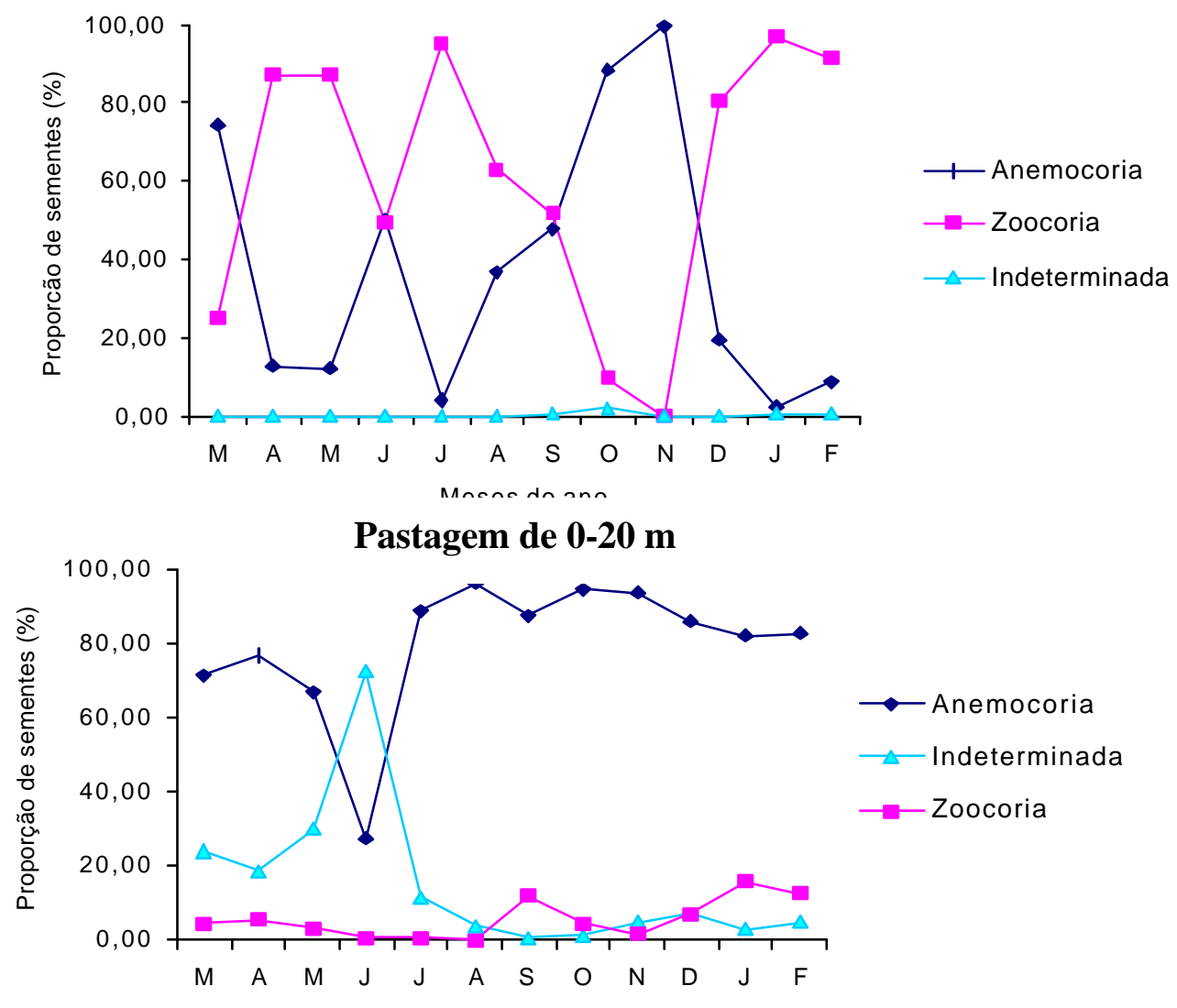

Pastagem de 80-100 m

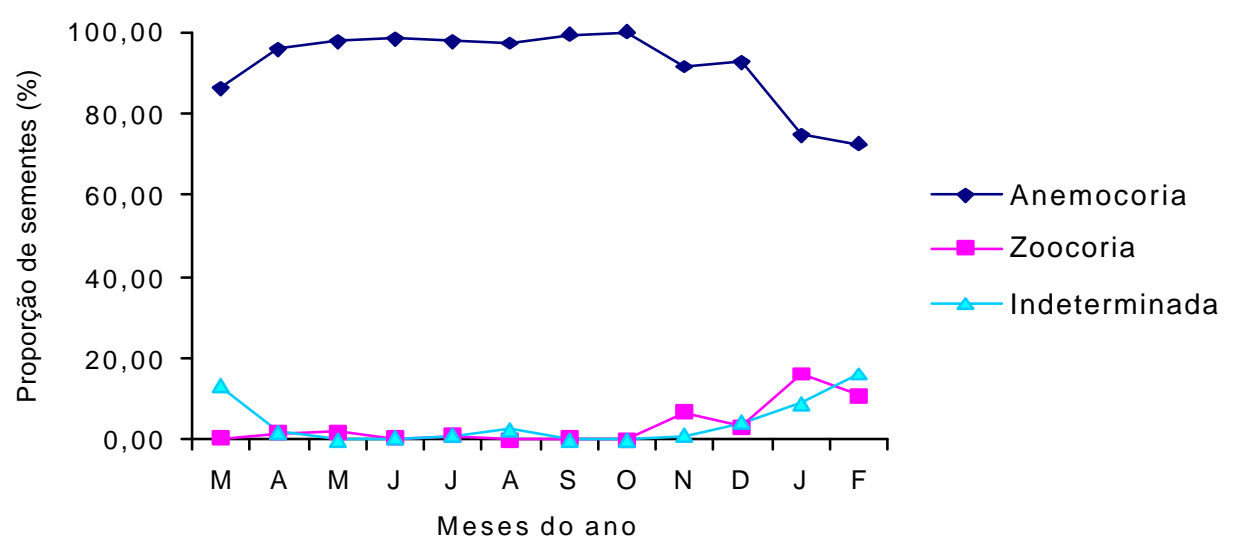

Figura 5 - Proporção de espécies agrupadas segundo a síndrome de dispersão encontradas mensalmente nos coletores durante o período de março de 2001 a fevereiro de 2002 no Parque Estadual do Jurupará, Ibiúna, SP, agrupados de acordo com a respectiva forma de vida, na área de Citrus sp, pastagem de 0-20m e 80-100 m de distância do remanescente florestal. 


\subsection{Discussão}

A chuva de sementes apresentou um alto número de sementes, com 125.214 sementes depositadas e uma densidade de 13.108,67 sem. $\mathrm{m}^{-2}$ no período de março de 2001 a fevereiro de 2002. Na área de Citrus sp foram encontradas 106.811 sementes com uma densidade de $33.546,17 \mathrm{sem} . \mathrm{m}^{-2}$. Na pastagem próxima ao remanescente florestal foram depositadas 8.636 sementess com uma densidade de 2.712,31 e na pastagem distante do remanescente florestal foram depositadas 9.767 sementes com uma densidade de 3.067,53 sem. $\mathrm{m}^{-2}$. Contudo, na pastagem a alta densidade amostrada foi praticamente atribuída às herbáceas. Se considerarmos neste trabalho apenas as espécies arbustivas e arbóreas na pastagem, a densidade de sementes cai bruscamente para 335,75 sem.m ${ }^{-2}$ e 577,58 sem.m , $^{-2}$, respectivamente para as faixas de 020 e 80-100m de distância do remanescente florestal. Embora estes valores sejam considerados baixos, ainda situam-se acima da média de 190 sem.m ${ }^{-2}$ obtidas na pastagem em um estudo com a chuva de sementes de espécies arbóreas, durante um ano de estudo, ambas em uma Floresta Tropical no sul da Costa Rica (Holl, 1999).

A área de citricultura apresentou alta densidade de sementes autóctones devido a apenas duas espécies arbustivo-arbóreas encontradas em idade reprodutiva na área amostral, que possuem frutos com sementes numerosas (Leandra sp e Tibouchina sp).

Previsões empíricas (Willson \& Crome, 1989) e estudos teóricos (Greene \& Johnson, 1996) sugerem que o número de sementes dispersas pelo vento declina em relação à distância da borda da floresta. Nesse estudo uma leve tendência para essa resposta foi observada para as espécies arbóreas Tibouchina sp e Clethra scabra na pastagem. Já Vernonia polyanthes não foi considerada uma espécie indicadora de dispersão proveniente do remanescente florestal, pois apesar de também tratar-se de espécie arbustivo-arbórea com dispersão anemocórica, apresentou indivíduos adultos reprodutivos isolados no interior da pastagem, que devem ser os fornecedores das sementes dessa espécie amostradas nos coletores. O mesmo ocorreu com as espécies herbáceas, já que esta forma de vida é característica da pastagem. Holl (1999) obteve o mesmo resultado, onde as $140 \mathrm{sem} . \mathrm{m}^{-2}$ registradas pertenciam a quatro 
espécies arbustivo-arbóreas presentes na pastagem, não podendo, desta forma, correlacionálas com a distância do remanescente florestal.

As espécies arbóreas encontradas na pastagem, Tibouchina sp, com densidade de $31,41 \mathrm{sem} \cdot \mathrm{m}^{-2}$ na área mais próxima e de $3,47 \mathrm{sem} \cdot \mathrm{m}^{-2}$ na área mais distante do remanescente florestal e, Clethra scabra, com densidade de 10,99 sem.m $\mathrm{m}^{-2}$ na área mais próxima e 7,22 sem. $\mathrm{m}^{-2}$ e na área mais distante do remanescente florestal, são caracterizadas como colonizadoras de grandes clareiras (pioneiras e secundárias iniciais, respectivamente), pois produzem grandes quantidades de sementes pequenas, possuem dispersão anemocórica, são fotoblásticas positivas e apresentam crescimento rápido (Whitmore, 1990; Smith, 1987). Willson (1993) verificou que espécies pioneiras dispersas pelo vento tendem a ter distribuição mais distante da árvore matriz que espécies zoocóricas. No entanto, esta distribuição é limitada, pois a densidade das espécies pioneiras declina logaritmicamente com a distância da copa da árvore-matriz. (Dalling et al., 1997; Alvarez-Buylla \& Martínez Ramos, 1990)

Em Florestas Tropicais, a síndrome de dispersão mais freqüente é a zoocórica, com ocorrência mínima de 50\% até mais de 75\%, na maioria dos trabalhos (Howe \& Smallwood, 1982). Contudo, áreas com pastagens apresentam baixa dispersão de sementes zoocóricas devido ao fato de que estas áreas oferecem pouco forrageamento para os frugívoros e alto risco de predação. Desta forma, raramente os animais se aventuram dentro de áreas abertas, limitando assim a dispersão de sementes zoocóricas nessa situação (Duncan, 1999; Silva et al., 1996).

No presente estudo, na área de Citrus $s p$, durante oito meses predominou a espécie zoocórica Leandra sp. Nessa área, também foram encontradas sementes de espécies arbóreas zoocóricas alóctones (Rapanea ferruginea - 24,50 sem.m $\mathrm{m}^{-2}$ e Ocotea sp - 0,94 sem.m ${ }^{-2}$ ), presentes no remanescente florestal do entorno, indicando que as espécies que regeneraram na área de Citrus sp, predominantemente Leandra sp, com síndrome de dispersão zoocórica, estaria atuando como espécie atratativa para a fauna. Apenas durante dois meses predominou a dispersão anemocórica, devido a predominância de Vernonia polyanthes, espécie pioneira, 
conhecida regionalmente como Assa-peixe e típica colonizadora de pastagens, com grande produção de sementes.

Já na pastagem estudada houve predomínio de anemocoria em detrimento de zoocoria, pois para as duas distâncias do remanescente florestal verificou-se duas espécies arbustivaarbóreas com síndrome de dispersão zoocórica Leandra sp e Psidium sp, sendo que a espécie Psidium sp não pode ser discutida, considerando suas sementes oriundas apenas do fragmento do entorno, já que possui representantes adultos reprodutivos no interior da pastagem.

Na área com Citrus sp foi encontrado 85,3\% (106.811 sementes, 57 espécies) de todas as sementes depositadas no período analisado, enquanto que na pastagem foi encontrado 14,7\% (18.370 sementes, 73 espécies), quando considera-se apenas as espécies arbutivoarbóreas, esta diferença aumenta consideravelmente com 97,4\% (106.236 sementes, 7 espécies) encontradas na área com Citrus sp e apenas 2,65\% (2.808 sementes, 5 espécies) encontradas na pastagem. A síndrome de dispersão predominante na área com Citrus sp foi a zoocórica com $52,71 \%$ das sementes encontradas, enquanto que na pastagem este tipo de dispersão ficou com $0,64 \%$. A dispersão anemocórica foi representada por 32,49\% das sementes encontradas na área de Citrus sp e $12,75 \%$ na pastagem.

As características da matriz degradada, principalmente as características da cobertura, relevo e posição em relação à direção do vento podem determinar a intensidade da chuva de sementes. As espécies adultas encontradas área de Citrus sp (Citrus sp, Leandra sp, Tibouchina sp) podem ter estimulado a dispersão zoocórica nesta área através da atração da fauna, atuando como puleiros, justificando, desta forma, as diferenças significativas encontrada para o número de sementes entre a área de Citrus $s p$ e pastagem.

Considerando apenas a pastagem, foi encontrado na faixa experimental mais próxima do remanescente florestal $46,9 \%$ de todas as sementes depositadas (8.636 sementes, 51 espécies), enquanto que na faixa mais distante foi encontrada $53,1 \%$ de todas as espécies depositadas (9.767 sementes, 52 espécies). Quando se avalia apenas as espécies arbustivoarbóreas, sem representantes adultos na pastagem, foi observado na faixa mais próxima 264 
sementes (3 espécies ) e na faixa mais distante, 51 sementes (2 espécies). A síndrome de dispersão predominante na pastagem foi a anemocórica, sendo encontrada na faixa mais próxima 8.155 sementes $(48,68 \%)$ e na faixa mais distante 7.787 sementes $(46,49 \%)$, enquanto que, a dispersão zoocórica apresentou na faixa próxima, 200 sementes $(1,19 \%)$ e na faixa mais distante 609 sementes $(3,63 \%)$.

A dispersão de sementes e a distância do remanescente florestal na pastagem não foram inversamente relacionados, como estabelecido na hipótese desse trabalho, nem o número de sementes dispersas por animais ou pelo vento foi significativamente relacionada com a distância da borda. Esse resultado também foi obtido por Holl (1999) em um estudo com a chuva de sementes em pastagens abandonadas no sul da Costa Rica, onde poucas sementes (3 sem. $\mathrm{m}^{-2}$ ) foram registradas na pastagem além dos $5 \mathrm{~m}$ da floresta do entorno.

A chuva de sementes é considerada como um dos mecanismos de grande importância na regeneração natural de áreas agropastoris abandonadas. As diferenças significativas encontradas entre Citrus sp e pastagem indicam que os puleiros podem funcionar como estimuladores da regeneração. Desta forma, quando a área não apresenta uma dispersão eficiente de sementes, deve-se proceder ao manejo da área com o plantio de espécies atrativas da fauna para tornar a área visitada por agentes dispersores, promovendo a quebra de uma das barreiras que possui grande influência na recuperação de tais áreas (Rodrigues \& Gandolfi, 1998).

\subsection{Conclusões}

A chegada de propágulos pode ser determinada pelas características vegetacionais da área estudada, já que foram encontradas diferenças significativas entre a área de Citrus $s p$ e pastagem. A chuva de sementes na área de Citrus sp apresentou uma densidade aproximadamente 10 vezes maior do que na pastagem. 
A chegada de propágulos na pastagem estudada não esta relacionada à distância do remanescente florestal, rejeitando a hipótese de que chegada de propágulos na pastagem esteja inversamente relacionada à distância do remanescente florestal.

Tanto na área de Citrus sp quanto na pastagem foi observada uma predominância de chuva de sementes de origem autóctone: Tibouchina sp e Leandra sp na área de Citrus sp e espécies ruderais na pastagem.

A baixa densidade de sementes arbustivo-arbórea provenientes do remanescente florestal na pastagem pode estar atuando como uma barreira inicial da regeneração da área. 


\title{
O BANCO DE SEMENTES E O ESTRATO DE REGENERAÇÃO DE TRECHOS DESFLORESTADOS, ATUALMENTE OCUPADOS COM O CULTIVO DE Citrus $s p$ E COM PASTAGEM, A DIFERENTES DISTÂNCIAS DO REMANESCENTE FLORESTAL NO INTERIOR DO PARQUE ESTADUAL DO JURUPARÁ, IBIÚNA, SÃO PAULO
}

\author{
Autora: Silvana Cristina Pereira Muniz de Souza \\ Orientador: Prof. Dr. Ricardo Ribeiro Rodrigues
}

\section{Resumo}

A resiliência de áreas degradadas ocupadas por Citrus sp e pastagem foram avaliadas através do banco de sementes e indivíduos jovens regenerantes, no interior do Parque Estadual do Jurupará ( $23^{\circ} 51^{\prime}$ S e $47^{\circ} 11^{\prime}$ W), em uma região de transição entre a Floresta Ombrófila Densa e a Floresta Estacional Semidecidual. Foram alocadas três faixas de amostragem, cada uma com 5 parcelas aleatorizadas de 10 X 20 m, sendo uma na área de cultivo de Citrus sp, e as duas restantes na pastagem a 0-20 m e 80-100 m de distância do remanescente florestal do entorno. $\mathrm{O}$ banco de sementes foi avaliado em duas épocas distintas: na estação chuvosa em janeiro/2001 e na estação seca em agosto/2001. Em cada uma destas épocas foram coletadas três sub-parcelas de $0,25 \mathrm{X} 0,25 \mathrm{~m}$ e profundidade de $0,05 \mathrm{~m}$ em cada parcela, totalizando por cada faixa experimental $0,94 \mathrm{~m}^{2}$ de solo coletado e nas três faixas experimentais $2,81 \mathrm{~m}^{2}$. As amostras foram incubadas no viveiro do próprio Parque Estadual do Jurupará a pleno sol. Os indivíduos jovens regenerantes foram avaliados em quatro subparcelas aleatórias de 0,5 X 0,5 m, em cada parcela, somando 5,0 $\mathrm{m}^{2}$ de área amostral em cada situação e $15 \mathrm{~m}^{2}$ total. Os 
indivíduos jovens foram amostrados em três avaliações: fevereiro/2001, agosto/2001 e fevereiro/2002, nas quais todos os indivíduos arbustivos-arbóreos com altura entre 0,30 m e 1,30 m foram marcados e identificados. Na área de Citrus $s p$, as espécies ruderais consistiram em 99,88\% das espécies germinadas do solo coletado na estação chuvosa, e 99,73\% do solo coletado na estação seca. Na pastagem, o solo coletado na estação chuvosa, para as duas distâncias, $100 \%$ das espécies germinadas foi composta por espécies herbáceas tipicamente ruderais. No solo coletado na estação seca, esta forma de vida foi predominante, com 99,66\% e 99,92\%, nas distâncias de 0-20 m e 80-100 m do remanescente florestal, respectivamente. No levantamento dos indivíduos jovens obteve-se densidade de 5,8 ind. $\mathrm{m}^{-2}$ na área de Citrus $s p$ e de 1,2 e 2,2 ind. $\mathrm{m}^{-2}$, na pastagem, a 0-20 m e 80-100 m de distância do remanescente florestal, respectivamente. Para os aspectos analisados não foram encontradas diferenças significativas entre as três faixas experimentais, rejeitando as hipóteses de que a característica da matriz degradada, Citrus sp e pastagem, define a presença de sementes no banco e de indivíduos jovens regenerantes e de que a resiliência da pastagem está inversamente relacionada com a distância do remanescente florestal.

\title{
THE SEED BANK AND THE REGENERATION STRATUM OF DEFORESTED AREAS CURRENTLY USED WITH Citrus sp AND PASTURE, IN DIFFERENT DISTANCES FROM THE REMAINING FOREST INSIDE THE JURUPARÁ STATE PARK, IBIÚNA, SÃO PAULO
}

\author{
Author: Silvana Cristina Pereira Muniz de Souza \\ Adviser: Prof. Dr. Ricardo Ribeiro Rodrigues
}

\section{Summary}

The resilience of a degraded area next to a remaining forest was evaluated inside the Jurupará State Park through a soil seed bank analysis and saplings in a transition area between 
the Ombrophil Forest and the Semideciduous Seasonal Forest. In this area, three sampling strips were allocated, each one with five parcels measuring $10 \times 20 \mathrm{~m}$, being one inside the Citrus $s p$ crop and the others inside the pasture distant 0-20 $\mathrm{m}$ and 80-100 $\mathrm{m}$ from the remaining forest. The seed bank was evaluated in two distinct seasons: in the rainy season (january/2001) and in the dry season (august/2001). It was collected in each season soil of three sub-parcels measuring $0.25 \times 0.25 \mathrm{~m}$ and $0.05 \mathrm{~m}$ in deep. With a total of $0.9375 \mathrm{~m}^{2}$. of soil for each experimental strip and in the three experimental strips $2.8125 \mathrm{~m}^{2}$. The samples were incubated in a nursery under the sun, located at the Park area. And for evaluating the saplings, four $0.5 \times 0.5 \mathrm{~m}$ sub-parcels were randomly implanted, in which three evaluations (feb/2001, aug/2001 and feb/2002) of all the shrubs-arboreal individuals, 0.30-1.30 m height, were performed and identified. At the soil seed bank inside the Citrus sp crop, the ruderal species were $99.88 \%$ in the soil collected in the rainy season and $99.73 \%$ in the soil collected in the dry season. In the experimental area inside the pasture, from the soil collected in the rainy season, for both distances, $100 \%$ of the germinated species was composed of herbal species typically ruderal, while in the soil collected in the dry season herbal pecies was predominant with $99.66 \%$ and $99.92 \%$ in both distances, respectively $0-20 \mathrm{~m}$ and $0-80 \mathrm{~m}$ distant from the remaning forest area. About the saplings counting, a density of 5.8 individual. $\mathrm{m}^{-2}$ was found inside the Citrus $s p$ crop and 1.2 individual.m

2 in the pasture distant $020 \mathrm{~m}$ from the remaining forest and 2.2 individual. $\mathrm{m}^{-2}$ in the pasture distant $80-100 \mathrm{~m}$ from the remaining forest. For the analyzed aspects, no significant differences were found among the three experimental strips, denying the hypothesis that the resilience of the study area is inversely related to the remaining forest distance.

\subsection{Introdução}

O banco de sementes em florestas tropicais está relacionado a pelo menos, quatro processos nos níveis de população e de comunidade: o estabelecimento de populações, a manutenção da diversidade de espécies, o estabelecimento de grupos ecológicos e a restauração 
da riqueza de espécies durante a regeneração natural da floresta após distúrbios naturais ou antrópicos (Harper, 1977; Uhl et al, 1988; Garwood, 1989).

O banco de sementes é considerado um dos principais indicadores do potencial de regeneração das florestas tropicais (Guevara \& Gómez-Pompa, 1972; Garwood, 1989). Em locais onde a floresta sofreu corte e queima, o estabelecimento de espécies pioneiras a partir do banco de sementes, é considerado um fator regulador da velocidade de regeneração (Uhl, 1987; Whitmore, 1990).

Nos solos tropicais, os bancos de semente, na sua maioria, são constituídos por ervas, arbustos e árvores pioneiras, que produzem sementes pequenas, enterradas, preferencialmente até 2,5 cm de profundidade (Baider, 1999). Muitas espécies estão presentes em baixa densidade no solo e somente um pequeno número de espécies são comuns no banco de sementes (Dalling et al., 1997). Esse padrão predomina, apesar das grandes diferenças de composição de espécies e de estratégias de dispersão observadas nas Florestas Tropicais (Gentry, 1988).

A determinação da viabilidade do banco de sementes em áreas com diferentes históricos de perturbação pode auxiliar na compreensão de como e onde as barreiras bióticas e abióticas atuam na regeneração, podendo contribuir para o conhecimento dos mecanismos sucessionais.

Este estudo tem como hipótese que a presença de sementes no banco é definida pelas características da matriz degradada e está inversamente relacionada à distância do remanescente florestal. Desta forma, o objetivo foi avaliar a viabilidade do banco de sementes em uma matriz degradada com diferentes cobertura vegetais Citrus sp e pastagem, sendo esta última avaliada a duas diferentes distâncias do remanescente florestal.

Além do banco de sementes, os estudos dos estratos inferiores também colaboram na interpretação da regeneração natural e revelam tanto a presença de espécies características deste estrato quanto de plântulas e indivíduos jovens de espécies arbóreas que irão atingir o dossel, mas podem constituir durante um período um banco de plântulas e indivíduos jovens (Swaine, 1996)

Nas florestas maduras tropicais e temperadas, o banco de sementes, em geral, é pobre e tende a ser substituído por uma reserva de plântulas que lhe é equivalente (Grime, 1986). Uma 
das possíveis explicações para esse tipo de estratégia seria evitar a predação, já que as sementes e os frutos de muitas espécies de Florestas Tropicais maduras são grandes e têm alto valor nutricional, tornado-se excelentes recursos para herbívoros. Desta forma, principalmente nas regiões tropicais, a estratégia predominante seria a germinação rápida e a persistência na forma de plântulas ou de indivíduos jovens por um período variável (Vásquez-Yanes \& OrozcoSegovia, 1987).

Um outro tipo de regeneração da Floresta Tropical, que geralmente ocorre após distúrbios, como corte e queima de árvores e arbustos, é a rebrota das partes vegetais remanescentes do distúrbio (caule, raiz) que se caracteriza por proporcionar uma regeneração mais rápida que a germinação a partir de sementes (Uhl et al., 1988).

Os padrões de crescimento e mortalidade diferem de acordo com as fases de desenvolvimento dos indivíduos florestais, sendo que a mortalidade é caracteristicamente maior entre plântulas e indivíduos jovens do que em árvores adultas (Lieberman et al. 1987). O estudo do estrato de regeneração é de crucial importância para a determinação do potencial de resiliência de uma área degradada.

Este estudo tem como hipótese que o potencial regeneração dos indivíduos jovens é definido pelas características da matriz degradada e está inversamente relacionado com a distância do remanescente florestal. Desta forma, o objetivo foi apresentar um levantamento florístico do estrato de regeneração em uma matriz degradada com diferentes cobertura vegetais Citrus sp e pastagem, sendo esta última avaliada a duas diferentes distâncias do remanescente florestal.

\subsection{Materiais e Métodos}

\subsubsection{Caracterização da área de estudo}

\subsubsection{Localização geográfica, características edafo-climáticas e vegetacionais}


O Parque Estadual do Jurupará está localizado no Estado de São Paulo na região do Vale do Ribeira, sobre o Planalto Atlântico (Alencar et al., 1976). Abrange os municípios de Ibiúna e Piedade, com uma área de 26.250,47 ha, com coordenadas geográficas $23^{\circ} 51^{\prime}$ a $24^{\circ} 02^{\prime}$ 'S e $47^{\circ} 11^{\prime}$ a $47^{\circ} 24^{\prime} \mathrm{W}$ (Anexo A).

A temperatura média anual é de $22^{\circ} \mathrm{C}$ e a precipitação pluviométrica anual oscila entre

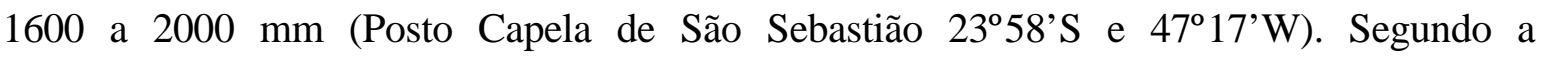
classificação de Köeppen (1948), o clima é do tipo Cfb, quente de inverno seco (Alencar, 1976; Aoki, 1982).

Os solos predominantes são: LATOSSOLO VERMELHO-AMARELO Distrófico câmbico (LVAd) de textura argilosa e o CAMBISSOLO HÁPLICO Tb Distrófico (CXvd) de textura argilosa ou argilosa com cascalhos. (Oliveira et al., 1999)

A vegetação local é considerada transicional entre a Floresta Ombrófila Densa e Floresta Estacional Semidecidual (Aragaki \& Mantovani, 1998).

\section{Caracterização do processo histórico de degradação}

As terras que compõem o Parque Estadual do Jurupará são devolutas, portanto pertencentes ao Estado de São Paulo. Em 1978, devido às características ambientais da área, parte do $2^{\circ}$ Perímetro de São Roque foi transformado em Reserva Estadual, sendo conhecida como Reserva Estadual do $2^{\circ}$ Perímetro de São Roque. Em 1992, esta Reserva foi transformada no Parque Estadual do Jurupará pelos decretos if 35.703 e 35.704, estando, atualmente, sob a administração do Instituto Florestal. No entanto, a questão fundiária desta Unidade de Conservação é complexa, já que se encontra quase que completamente ocupada por pequenas propriedades.

A partir de 1978, todas as intervenções praticadas no interior da Unidade de Conservação já eram consideradas irregulares e, em virtude de impactos ambientais praticados por um dos ocupantes do Parque e em decorrência de ação civil pública em 1998, houve a 
reintegração de posse pelo Estado de três fazendas, Sete Lagos, Tucano e Km 40, somando aproximadamente 800 ha sob o domínio do Instituto Florestal

A área experimental desse trabalho localiza-se no interior da antiga Fazenda Tucano, que desde da década a 70 vem sofrendo degradação antrópica que se intensificou a partir de 1985, com o corte de extensas áreas de floresta nativa, seguido de queima. Grande parte destas áreas, logo após a degradação, foram destinadas para atividades agropastoris, com a predominância de utilização para pastagens.

Em uma área de aproximadamente dois hectares adjacente ao remanescente florestal foi introduzida a espécie Citrus latifolia Tanaka (limão Tahiti) em enxertia sob a espécie Citrus limonia L. Osbeck (limão Cravo), e no restante da área (aproximadamente 10ha) foram introduzidas espécies de forrageiras exóticas, Urochloa decumbens (Stapf) Webster e Urochloa humidicola (Rendle) Morrone \& Zuloaga (antigo gênero Brachiaria) para a utilização desta área como pastagem (Anexo B e C). Estas áreas foram manejadas para produção, sendo que a área destinada ao cultivo do Citrus sp teve o seu subosque periodicamente limpo e a área destinada a pastagem foi frequentemente queimada e roçada.

A efetiva interdição dessas áreas foi realizada em 1992, estando, portanto, atualmente com 10 anos de abandono.

A área com citricultura apresenta-se atualmente em estágio inicial a intermediário de regeneração natural e um dossel de aproximadamente $4 \mathrm{~m}$ de altura, com a predominância na regeneração de espécies da família Melastomataceae, destacando-se Leandra sp e Clidemia $s p$, no subosque, e Tibouchina sp, no dossel. Embora muitos limoeiros estejam no subosque sombreados por regenerantes, ainda encontram-se produtivos (Anexo C).

Apesar da pastagem ter sido abandonada na mesma época que área com citricultura, não há, a princípio, sinais de regeneração natural condizente com o tempo de abandono, apresentando uma cobertura vegetal constituída predominantemente pelas espécies inicialmente introduzidas e por espécies herbáceas, em especial ruderais invasoras de pastagens com alguns poucos arbustos esparsos: Psidium guajava, Psidium cattleianum, Rapanea ferruginea e Vernonia polyanthes. (Anexo B). 


\subsubsection{Alocação das parcelas}

Foram instaladas três faixas de amostragem: duas na pastagem e uma no interior do cultivo de Citrus sp. Para a implementação de cada faixa foi delimitada uma área de $3000 \mathrm{~m}^{2}$ (20 m de largura e $150 \mathrm{~m}$ de comprimento), onde foram demarcadas 15 parcelas de $10 \mathrm{X} 20 \mathrm{~m}$. No interior de cada faixa foi realizada uma amostragem aleatória (IBGE, 1992), de cinco parcelas (Anexo D).

As parcelas instaladas na pastagem foram alocadas na distância de 0-20 m e 80-100 m do remanescente florestal. Já as parcelas instaladas no interior do cultivo de Citrus $s p$ encontram-se aleatoriamente distribuídas em seu interior.

A instalação das sub-parcelas foi realizada com o auxílio de trena e bússola, sendo estas localizadas pelas coordenadas $\mathrm{X}$ e $\mathrm{Y}$ da parcela, considerando a coordenada $\mathrm{X}$ a largura da parcela $(10 \mathrm{~m})$ e $\mathrm{Y}$ o comprimento $(20 \mathrm{~m})$. As parcelas foram delimitadas com material permanente (canos de PVC preenchidos com cimento), permitindo reavaliações futuras. Para a amostragem desse estudo foi utilizado barbante para delimitar visualmente as parcelas.

No interior de cada parcela sorteada foram alocados 3 coletores de sementes, para a avaliação da chuva de sementes (Anexo D).

\subsubsection{Banco de sementes}

No experimento, foi realizada a análise da composição e densidade do estoque de sementes presentes no solo da área de estudo através do método de incubação, no qual o solo foi incubado a pleno sol, para quantificar o número de sementes, considerando a emergência de plântulas (Heerdt et al., 1996). Este método é o mais frequientemente utilizado em trabalhos com banco de sementes, e o mais adequado para os estudos sinecológicos (Simpson et al, 1989). 
Duas coletas semestrais do banco de sementes foram realizadas, a primeira na estação chuvosa (janeiro/2001) e a segunda, na estação seca (agosto/2001), para verificar variação sazonal no banco de sementes.

Foram coletadas três amostras ao acaso em cada parcela, sendo 15 amostras em cada faixa, totalizando 45 amostras semestrais nas três faixas experimentais.

Cada unidade amostral possui $0,25 \times 0,25 \mathrm{~m}\left(0,0625 \mathrm{~m}^{2}\right)$ com $0,05 \mathrm{~m}$ de profundidade, totalizando por cada faixa experimental de $0,9375 \mathrm{~m}^{2}$ de solo coletado e nas três faixas experimentais $2,8125 \mathrm{~m}^{2}$ o volume total foi de $0,1406 \mathrm{~m}^{3}$.

Para a coleta do solo foi utilizada uma espátula (Figura 1), a serapilheira também coletada,pois abriga uma percentagem razoável das sementes constituintes do banco (Garwood, 1989).

O solo e serapilheira coletados foram acondicionados em saco plásticos pretos, devidamente identificados e transportados até o viveiro do Parque Estadual do Jurupará. Cada amostra de solo foi revolvida e a serapilheira correspondente triada retirando-se folhas grandes e galhos.

O solo e a serrapilheira foram colocados em bandejas plásticas (com dimensões de 0,38 X 0,25 X 0,06 m), dispostas no germinador do viveiro, sendo que a cada quatro bandejas com solo coletado foi adicionada uma bandeja com solo estéril, totalizando 10 bandejas controle para identificar diásporos provenientes das áreas do entorno do viveiro. O solo incubado foi colocado a pleno sol com irrigação periódica, de modo a manter as condições adequadas à germinação.

A condição de luminosidade total foi escolhida por simular a condição das grandes clareiras, para estimular a germinação das espécies pioneiras, fotoblásticas positivas, que são responsáveis pela ocupação inicial de uma área degradada e desencadearia o processo de recuperação dessa área (Figura 2). 


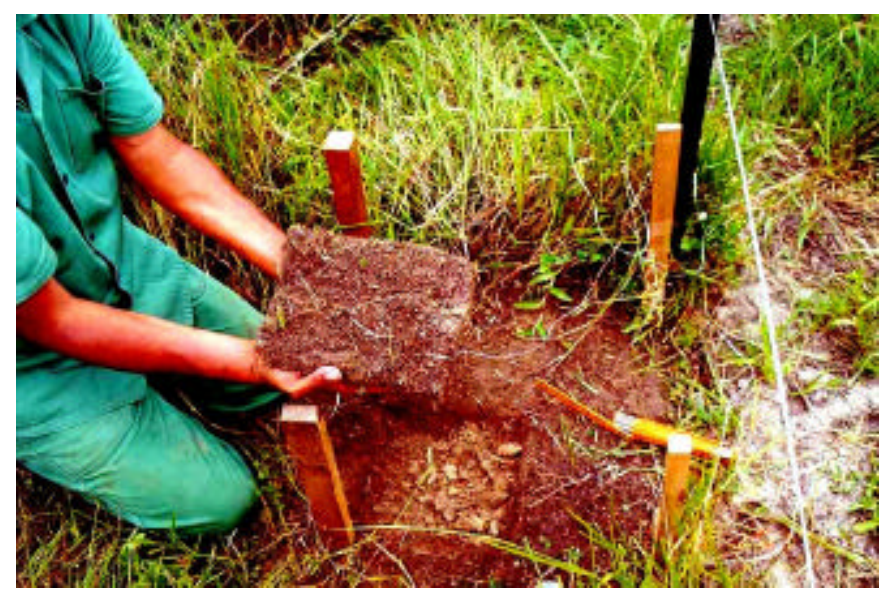

Figura 1 - Amostra de solo de 0,25 X 0,25 m e 0,05 m de profundidade, coletado para análise do banco de sementes no interior do Parque Estadual do Jurupará, Ibiúna, São Paulo.

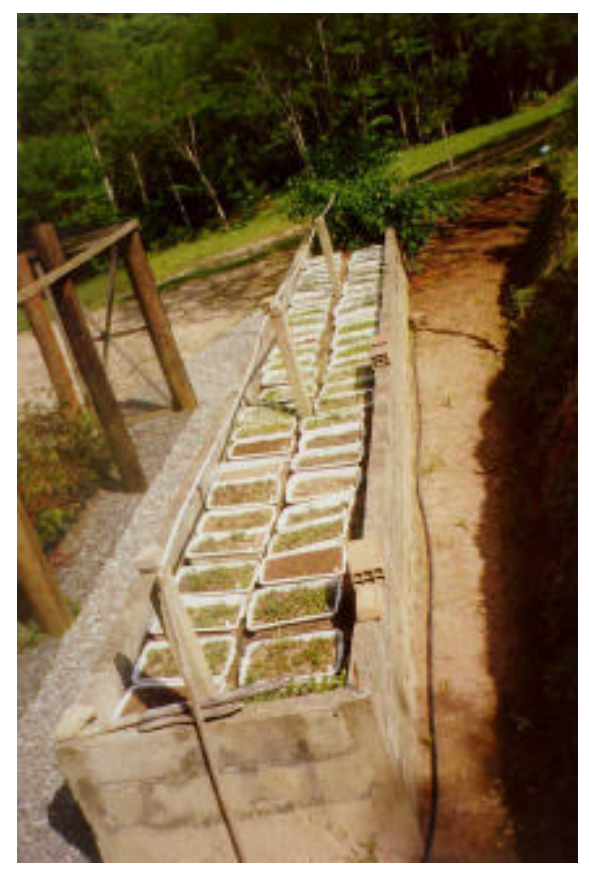

Figura 2 - Vista geral do germinador do viveiro, com as bandejas contendo solo coletado para avaliação do banco de sementes do Parque Estadual do Jurupará, Ibiúna, São Paulo. 
Mensalmente, pelo período de um ano, foram realizadas as avaliações da germinação nas bandejas. A cada dois meses de avaliação, todas as plântulas identificadas foram retiradas e o solo revolvido para promover a germinação de sementes que pudessem ter ficado enterradas ou sombreadas. Para confirmar a identificação, pelo menos um indivíduo de cada espécie encontrada foi transplantado para sacos plásticos, e o seu desenvolvimento foi acompanhado até que fosse possível a identificação segura. A identificação do material foi realizada pelos responsáveis do trabalho mediante a consulta de literatura especializada, especialistas e consulta a material de herbário.

O acompanhamento da germinação de plântulas foi realizado de fevereiro de 2001 até fevereiro de 2002.

Foi realizado, cálculo de média e desvio padrão para cada faixa experimental. Para cada espécie foi verificada síndrome de dispersão e grupo ecológico (apenas para as espécies arbustivo-arbóreas).

Foi realizado o teste de análise de variância Kruskal-Wallis (Zar, 1984) do número de sementes germinadas para testar se houve diferenças significativas entre a área de Citrus $s p$ e pastagem e entre as diferentes distâncias na pastagem.

\subsubsection{Estrato de regeneração}

Em cada parcela selecionada foi realizada a caracterização da regeneração natural em quatro sub-parcelas aleatórias, medindo cada uma 0,5 X 0,5 m, amostrando uma área de 5,0 $\mathrm{m}^{2}$ em cada faixa, totalizando $15 \mathrm{~m}^{2}$ de área total amostrada nas três faixas experimentais.

O critério de amostragem inclui indivíduos jovens arbustivos-arbóreos, cujas alturas estiveram entre 0,30 e $1,30 \mathrm{~m}$. Todos os indivíduos encontrados foram devidamente identificados com etiquetas plásticas numeradas, anotando-se a altura a cada avaliação (Figura 3). 


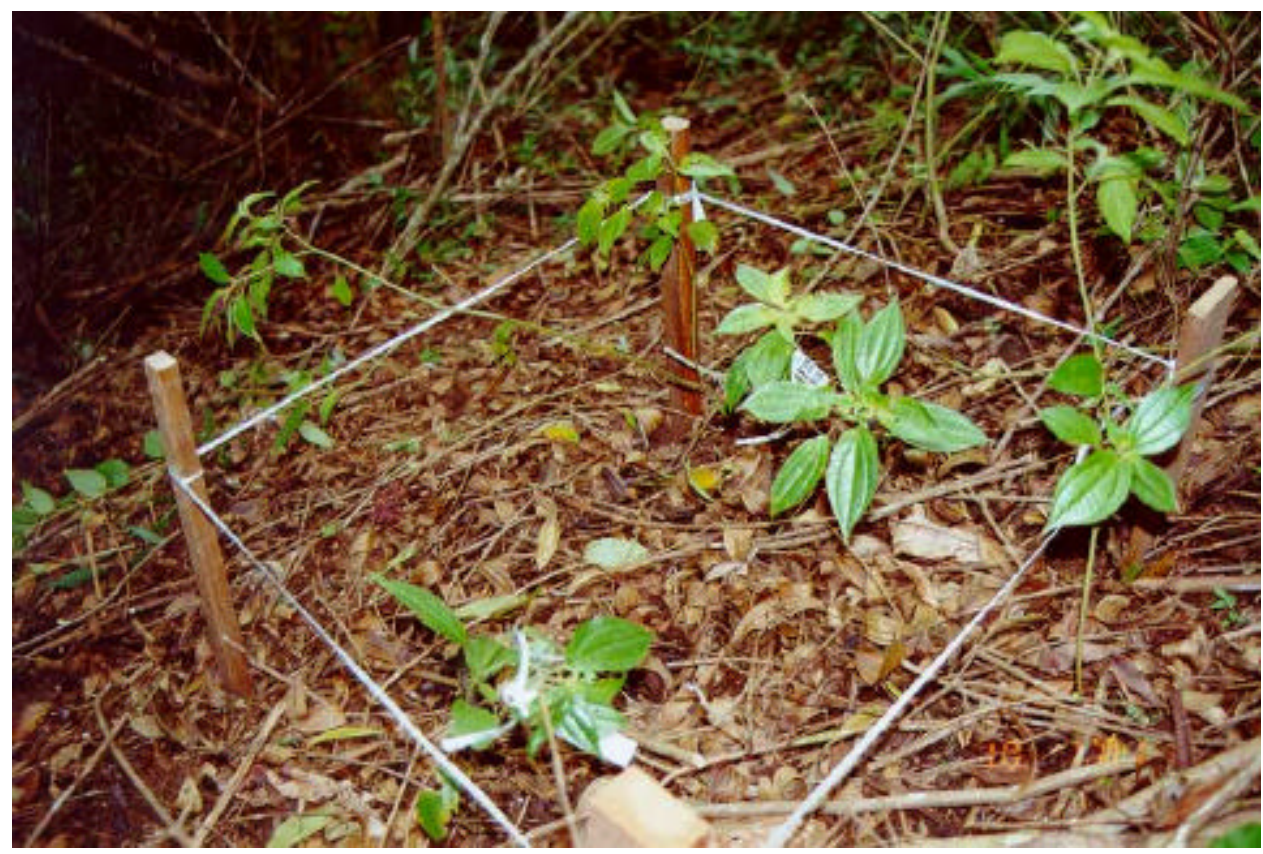

Figura 3 - Sub-parcela de 0,5 X 0,5 m instalada para identificar indivíduos jovens regenerantes no interior do Parque Estadual do Jurupará, município de Ibiúna, São Paulo

Foram realizadas três avaliações, nos seguintes meses, fevereiro de 2001, agosto de 2001 e fevereiro de 2002, completando um ano de acompanhamento.

Depois da última avaliação os indivíduos tiveram o material botânico coletado para confirmação da identificação mediante consulta a literatura, comparação com material de herbário e auxílio de especialistas.

As espécies amostradas no estrato de regeneração foram classificadas quanto a síndrome de dispersão e grupo ecológico.

\subsection{Resultados}

\subsubsection{Banco de sementes}

A partir das duas coletas de solo germinaram 8.754 sementes, sendo que no solo coletado na estação chuvosa (janeiro/2001) germinaram 4.225 sementes (21 espécies) e no solo coletado na estação seca (agosto/2001) germinaram 4.529 sementes (25 espécies). A densidade 
absoluta de sementes germinadas foi de 1.502,22 sem. $\mathrm{m}^{-2}$ na estação chuvosa e de 1.610,31 sem.m. $m^{-2}$ na estação seca.

Os valores de densidade absoluta das sementes que germinaram do solo coletado nas três faixas amostrais, nas duas coletas (janeiro/2001 e agosto/2001) são apresentados na Tabela 1.

Tabela 1. Densidade total de sementes germinadas a partir do banco de sementes nas duas coletas: estação chuvosa (janeiro/2001) e estação seca (agosto/2001) nas três faixas experimentais, no interior do Parque Estadual do Jurupará, município de Ibiúna, São Paulo.

\begin{tabular}{lccc}
\hline \multicolumn{1}{c}{ Coletas } & Citrus $s p$ & \multicolumn{2}{c}{ Faixas } \\
& & $0-20 \mathrm{~m}$ & $80-100 \mathrm{~m}$ \\
\hline Estação chuvosa $\left(\mathrm{sem} \cdot \mathrm{m}^{-2}\right)$ & $1.731,20$ & $1.086,93$ & $1.636,18$ \\
Estação seca $\left(\mathrm{sem} . \mathrm{m}^{-2}\right)$ & $1.587,20$ & $1.889,07$ & $1.354,67$ \\
\hline
\end{tabular}

Os valores médios e desvio padrão das sementes germinadas em cada faixa experimental a partir do banco de sementes do solo coletado respectivamente, em janeiro/2001 (estação chuvosa) e agosto/2001 (estação seca) são apresentados na Tabela 2. 
Tabela 2. Média (X) e desvio padrão $(\rho)$ observado em cada faixa experimental de sementes que germinaram a partir do banco de sementes coletado em janeiro/2001 (estação chuvosa) e agosto/2001 (estação seca) no interior do Parque Estadual do Jurupará, município de Ibiúna, SãoPaulo.

\begin{tabular}{|c|c|c|c|c|c|c|}
\hline \multirow{4}{*}{ Coleta } & \multicolumn{6}{|c|}{ Faixas } \\
\hline & \multicolumn{2}{|c|}{ Citrus sp } & \multicolumn{4}{|c|}{ Pastagem } \\
\hline & \multirow[b]{2}{*}{ Árvores } & \multirow[b]{2}{*}{ Ervas } & \multicolumn{2}{|c|}{$0-20 \mathrm{~m}$} & \multicolumn{2}{|c|}{$80-100 \mathrm{~m}$} \\
\hline & & & Árvores & Ervas & Árvores & Ervas \\
\hline $\begin{array}{c}\mathrm{Jan} / 2001 \\
(\mathrm{X} \pm \rho)\end{array}$ & $0,13 \pm 0,18$ & $108,2 \pm 46,27$ & 0,00 & $67,60 \pm 23,88$ & 0,00 & $104,87 \pm 58,27$ \\
\hline $\begin{array}{c}\mathrm{Ago} / 2001 \\
(X \pm \rho)\end{array}$ & $0,27 \pm 0,15$ & $99,47 \pm 17,15$ & $0,60 \pm 0,89$ & $118,00 \pm 73,43$ & $0,53 \pm 0,50$ & $87,27 \pm 53,14$ \\
\hline
\end{tabular}

A faixa amostral em que germinou um maior número de espécies foi a no interior do cultivo de Citrus sp, com 27 espécies, sendo 22 herbáceas e cinco arbóreas, seguida da faixa experimental na pastagem a 80-100 m de distância do remanescente, com 23 espécies, 22 espécies herbáceas e uma arbórea e a faixa na pastagem a 0-20 m de distância do remanescente florestal, foram, identificadas 17 espécies herbáceas e duas arbóreas (Tabelas 3, 4, 5).

Na área de Citrus sp, o solo coletado na estação chuvosa, verificou-se que 99,88\% das sementes germinadas eram herbáceas e 0,12\% arbóreas, sendo esta última representada por um indivíduo de duas espécies (Trema micrantha e Senna multijuga, ambas com densidadade absoluta de 1,07 sem.m ${ }^{-2}$ ). Nesta mesma área, o solo coletado na estação seca (Tabela 3) 99,73\% eram herbáceas e 0,26\% arbórea, representada por um indivíduo de Bacharis dracunculifolia, Myrcia crassifolia, Alchornea triplinervia e Trema micrantha, todas com densidade absoluta de 1,07 sem. $\mathrm{m}^{-2}$.

Na pastagem as espécies herbáceas representaram 100\% das sementes germinadas no solo coletado na estação chuvosa. Na estação seca as espécies herbáceas representaram 99,49\% na pastagem de 0-20 m de distância do remanescente florestal e 99,39\% na pastagem de 80-100 m de distância do remanescente florestal. As espécies arbóreas encontradas na 
pastagem próxima do remanescente florestal representaram $0,51 \%$ do total de sementes germinadas, referindo-se a seis indivíduos Trema micrantha (densidade de 6,4 sem. $\mathrm{m}^{-2}$ ). Na pastagem distante do remanescente florestal, as espécies arbóreas representaram 0,61\% das sementes germinadas pertencente a oito indivíduos de Bacharis dracunculifolia (densidade de $\left.8,53 \mathrm{sem} \cdot \mathrm{m}^{-2}\right)($ Tabelas 4 e 5).

A comparação da composição de espécies arbóreas do banco de sementes com as espécies amostradas nos levantamentos florísticos realizados na mesma formação florestal e próximos ao local de estudo são apresentados na Tabela 6.

Tabela 6. Comparação dos resultados obtidos das espécies arbóreas germinadas a partir do banco de sementes coletado no interior do Parque Estadual do Jurupará, Ibiúna, São Paulo com levantamentos florísticos realizados sobre a mesma formação florestal no estado de São Paulo.

\begin{tabular}{|c|c|c|c|c|}
\hline Trabalho & $\begin{array}{c}\text { Esteves et al. } \\
\text { (1995) }\end{array}$ & $\begin{array}{c}\text { Cardoso } \\
\text { Leite (1995) }\end{array}$ & $\begin{array}{c}\text { Nascimento } \\
\text { (1994) }\end{array}$ & $\begin{array}{c}\text { Albuquerque } \\
\text { (1999) }\end{array}$ \\
\hline $\begin{array}{c}\text { Municípios/ } \\
\text { Espécies do banco }\end{array}$ & Ibiúna & São Roque & Ribeirão Grande & Iperó \\
\hline Alchornea triplinervia & $X$ & --- & --- & --- \\
\hline Bacharis dracunculifolia & --- & --- & $X$ & --- \\
\hline Myrcia crassifolia & --- & --- & --- & --- \\
\hline Senna multijuga & $X$ & $\mathrm{X}$ & $\mathrm{X}$ & $X$ \\
\hline Trema micrantha & $\mathrm{X}$ & $X$ & --- & --- \\
\hline
\end{tabular}

No teste de análise de variância (Kruskal-Wallis) realizado com o número de sementes germinadas, não foram encontradas diferenças significativas entre as três faixas experimentais para as espécies arbustivo-arbóreas nas duas coletas realizadas $\left(\chi^{2}=3,7320\right.$ e $\left.\mathrm{P}=0,15\right)$. 
Tabela 3. Número de sementes, síndrome de dispersão e forma de vida das espécies que germinaram a partir do banco de sementes do solo coletado na $1^{\mathrm{a}}$ e $2^{\mathrm{a}}$ coleta (janeiro e agosto de 2001) da área amostral no interior do cultivo de Citrus sp, no Parque Estadual do Jurupará, município de Ibiúna, São Paulo. arv = arbórea, anemo = anemocórica, auto = autocórica, herb = herbácea, pio = pioneira, $z 00=$ zoocórica .

\begin{tabular}{|c|c|c|c|c|}
\hline Espécies & $\begin{array}{c}1^{\mathrm{a}} \\
\text { Coleta } \\
\text { Número } \\
\text { de } \\
\text { sementes }\end{array}$ & $\begin{array}{c}2^{\mathrm{a}} \\
\text { Coleta } \\
\text { Número } \\
\text { de } \\
\text { sementes }\end{array}$ & $\begin{array}{c}\text { Síndrome } \\
\text { de } \\
\text { dispersão }\end{array}$ & $\begin{array}{c}\text { Forma de } \\
\text { vida }\end{array}$ \\
\hline Alchornea triplinervia (Spreng.) Müll.Arg. & 0 & 1 & auto & arv \\
\hline Bacharis dracunculifolia DC. & 0 & 1 & anem & $\operatorname{arv}$ \\
\hline Myrcia crassifolia & 0 & 1 & zoo & arv \\
\hline Senna multijuga H.S.Irwin \& Barneby & 1 & 0 & anem & arv \\
\hline Trema micrantha (L.) Blume & 1 & 1 & ZOO & herb \\
\hline Chloris gayana Kunth. & 628 & 514 & anem & herb \\
\hline Fimbristylis dichotoma (L.) Vahl. & 412 & 437 & anem & herb \\
\hline Diodia alata Ness \& C. Mart & 178 & 120 & zoo/anem & herb \\
\hline Commelina erecta $\mathrm{L}$. & 160 & 326 & anem & herb \\
\hline Urochloa sp & 124 & 6 & zoo/anem & herb \\
\hline Sida sp & 60 & 2 & zOO & herb \\
\hline Eupatorium $s p$ & 19 & 0 & anem & herb \\
\hline Cuphea carthagenensis (Jacq.) J.F. Macbr & 13 & 29 & anem & herb \\
\hline Phyllanthus tenellus Roxb. & 12 & 9 & anem & herb \\
\hline Centella asiatica (L.) Urb. & 3 & 13 & anem & herb \\
\hline Panicum sp & 0 & 10 & anem & herb \\
\hline Jaegeria hirta (Lag.) Less. & 8 & 0 & anem & herb \\
\hline Amaranthus sp & 0 & 8 & anem & herb \\
\hline Erigeron $s p$ & 0 & 4 & anem & herb \\
\hline Scoparia dulcis L. & 0 & 3 & anem & herb \\
\hline Fimbristylis autumnalis L. & 0 & 1 & anem & herb \\
\hline Ageratum conyzoides L. & 0 & 1 & anem & herb \\
\hline Rubus brasiliensis Mart. & 0 & 1 & zoO & herb \\
\hline Asclepias currassavica L. & 1 & 0 & anem & herb \\
\hline Gnaphalium spicatum Lam & 1 & 0 & anem & herb \\
\hline Melinis minutiflora P. Beauv. & 1 & 0 & anem & herb \\
\hline Spilanthes sp & 1 & 0 & anem & herb \\
\hline TOTAL (27 espécies) & 1623 & 1488 & --- & --- \\
\hline
\end{tabular}


Tabela 4. Número de sementes, síndrome de dispersão e forma de vida das espécies que germinaram a partir do banco de sementes do solo coletado na $1^{\mathrm{a}}$ e $2^{\mathrm{a}}$ coleta (janeiro e agosto de 2001, respectivamente) da área amostral na pastagem a 0-20 m do remanescente florestal, no Parque Estadual do Jurupará, município de Ibiúna, São Paulo. arv = arbórea, anem = anemocórica, auto = autocórica, herb = herbácea, pio = pioneira, zoo = zoocórica.

\begin{tabular}{|c|c|c|c|c|}
\hline Espécies & $\begin{array}{c}1^{\mathrm{a}} \\
\text { Coleta } \\
\text { Número } \\
\text { de } \\
\text { sementes }\end{array}$ & $\begin{array}{c}2^{\mathrm{a}} \\
\text { Coleta } \\
\text { Número } \\
\text { de } \\
\text { sementes }\end{array}$ & $\begin{array}{c}\text { Síndrome } \\
\text { de } \\
\text { dispersão }\end{array}$ & $\begin{array}{c}\text { Forma de } \\
\text { vida }\end{array}$ \\
\hline Trema micrantha (L.) Blume & 0 & 6 & zOO & $\operatorname{arv}$ \\
\hline Senna multijuga H.S.Irwin \& Barneby & 0 & 3 & anem & arv \\
\hline Fimbristylis dichotoma (L.) Vahl. & 482 & 1147 & anem & herb \\
\hline Cuphea carthagenensis (Jacq.)J.F. Macbr & 160 & 270 & anem & herb \\
\hline Sida $s p$ & 139 & 18 & zoo & herb \\
\hline Diodia alata Ness \& C. Mart & 80 & 45 & anem & herb \\
\hline Urochloa decumbens (Stapf) Webster & 45 & 36 & zoo/anem & herb \\
\hline Fimbristylis autumnalis(L.) Roem \& Schult & 45 & 33 & anem & herb \\
\hline Chloris gayana Kunth. & 35 & 69 & anem & herb \\
\hline Centella asiatica (L.) Urb. & 12 & 42 & anem & herb \\
\hline Stachytarpheta cayennensis (L.P.Rich) Vahl. & 9 & 6 & anem & herb \\
\hline Commelina sp & 6 & 41 & anem & herb \\
\hline Phyllanthus tenellus Roxb. & 5 & 17 & anem & herb \\
\hline Ageratum conyzoides L. & 1 & 32 & anem & herb \\
\hline Scoparia dulcis L. & 0 & 4 & anem & herb \\
\hline Elephantopus mollis H.B.K. & 0 & 2 & anem & herb \\
\hline Amaranthus sp & 0 & 1 & anem & herb \\
\hline Cardanine bonariensis Pers. & 0 & 1 & anem & herb \\
\hline Gnaphalium spicatum Lam. & 0 & 1 & anem & herb \\
\hline TOTAL (19 espécies) & 1019 & 1771 & --- & --- \\
\hline
\end{tabular}


Tabela 5. Número de sementes, síndrome de dispersão e forma de vida das espécies que germinaram a partir do banco de sementes do solo coletado na $1^{\mathrm{a}}$ e $2^{\mathrm{a}}$ coleta (janeiro e agosto de 2001, respectivamente) da área amostral na pastagem a 80-100 m do remanescente florestal, no Parque Estadual do Jurupará, município de Ibiúna, São Paulo. arv = arbórea, anem = anemocórica, auto = autocórica, herb = herbácea, pio = pioneira, zoo = zoocórica.

\begin{tabular}{|c|c|c|c|c|}
\hline Espécies & $\begin{array}{c}1^{\mathrm{a}} \\
\text { Coleta } \\
\text { Número } \\
\text { de } \\
\text { sementes }\end{array}$ & $\begin{array}{c}2^{\mathrm{a}} \\
\text { Coleta } \\
\text { Número } \\
\text { de } \\
\text { sementes }\end{array}$ & $\begin{array}{c}\text { Síndrome } \\
\text { de } \\
\text { dispersão }\end{array}$ & $\begin{array}{c}\text { Forma de } \\
\text { vida }\end{array}$ \\
\hline Senna multijuga H.S.Irwin \& Barneby & 0 & 1 & anem & $\operatorname{arv}$ \\
\hline Fimbristylis dichotoma (L.) Vahl. & 692 & 677 & anem & herb \\
\hline Sida $s p$ & 473 & 95 & zoo & herb \\
\hline Cuphea carthagenensis (Jacq.)J.F. Macbr & 56 & 229 & anem & herb \\
\hline Urochloa sp & 102 & 22 & zoo/anem & herb \\
\hline Diodia alata Ness \& C. Mart & 89 & 24 & anem & herb \\
\hline Ageratum conyzoides $\mathrm{L}$. & 40 & 84 & anem & herb \\
\hline Stachytarpheta cayennensis (L.P. Rich)Vahl & 59 & 4 & anem & herb \\
\hline Scoparia dulcis L. & 0 & 30 & anem & herb \\
\hline Chloris gayana Kunth. & 19 & 24 & anem & herb \\
\hline Centella asiatica (L.) Urb. & 20 & 22 & anem & herb \\
\hline Fimbristylis autumnalis L. Roem \& Schult & 8 & 14 & anem & herb \\
\hline Urochloa decumbens (Stapf) Webster & 9 & 13 & zoo/anem & herb \\
\hline Jaegeria hirta (Lag.) Less. & 14 & 0 & anem & herb \\
\hline Commelina sp & 0 & 12 & anem & herb \\
\hline Gnaphalium spicatum Lam & 1 & 5 & anem & herb \\
\hline Amaranthus sp & 0 & 5 & anem & herb \\
\hline Cardanine bonariensis Pers. & 0 & 3 & anem & herb \\
\hline Panicum sp & 0 & 2 & anem & herb \\
\hline Phyllanthus tenellus Roxb. & 0 & 2 & auto/anem & herb \\
\hline Desmodium uncinatum (Jacq.) DC. & 0 & 1 & $\mathrm{zOO}$ & herb \\
\hline Erigeron bonariensis (L.) Cronq. & 0 & 1 & anem & herb \\
\hline Scleria pterota Presl & 1 & 0 & anem & herb \\
\hline TOTAL (23 espécies) & 1583 & 1270 & --- & --- \\
\hline
\end{tabular}




\subsubsection{Estrato de regeneração}

A partir do levantamento de indivíduos jovens realizado em três avaliações amostrou-se 44 indivíduos pertencentes a 11 espécies e oito famílias. A densidade absoluta foi de 2,93 indivíduos.m $\mathrm{m}^{-2}$.

Os valores médios e desvios-padrão por parcela em cada faixa experimental de indivíduos jovens regenerantes nas três avaliações (janeiro/2001, agosto/2001 e fevereiro/2002) são apresentados na Tabela 1 .

Tabela 1. Média (X) e desvio padrão $(\rho)$ de cada parcela por faixa experimental de indivíduos jovens arbustivos-arbóreos encontrados no interior do Parque Estadual do Jurupará, município de Ibiúna, São Paulo.

\begin{tabular}{lccc}
\hline & Cultivo de Citrus sp & \multicolumn{2}{c}{ Pastagem } \\
Avaliações & $\mathrm{X} \pm \rho$ & $0-20 \mathrm{~m}$ & $80-100 \mathrm{~m}$ \\
\hline Janeiro/2001 & $2,20 \pm 2,77$ & $0,4 \pm 0,89$ & $\mathrm{X} \pm \rho$ \\
Agosto/2001 & $4,00 \pm 3,31$ & $1,20 \pm 1,79$ & $0,80 \pm 1,30$ \\
Fevereiro/2002 & $5,00 \pm 3,16$ & $1,20 \pm 1,79$ & $2,00 \pm 1,52$ \\
& & & \\
\hline
\end{tabular}

No levantamento de indivíduos jovens na área de Citrus sp, foram encontradas oito espécies arbustivo-arbóreas, pertencentes a sete famílias. Considerando a última avaliação (fevereiro/2002), a densidade encontrada foi de 5,8 indivíduos. $\mathrm{m}^{-2}$. A espécie dominante foi Leandra $s p$, . com densidade relativa de $64,0 \%$. Houve incremento no número total de indivíduos, de $81 \%$ da primeira para a segunda avaliação, e desta última para a terceira avaliação de $25 \%$ (Tabelas 2, 3).

Na pastagem a 0-20 m de distância do remanescente florestal fram encontradas quatro espécies, pertencentes a três famílias. Considerando a última avaliação a densidade encontrada foi de 1,2 indivíduos.m ${ }^{-2}$. As espécies dominantes foram Leandra sp. e Trema 
micrantha, ambas com densidade relativa de $33 \%$. Houve incremento no número total de indivíduos de $200 \%$ da primeira para a segunda avaliação. Não houve aumento no número de indivíduos da segunda (Tabelas 2, 3).

Na pastagem a 80-100 m de distância do remanescente florestal, foram encontradas quatro espécies, pertencentes a quatro famílias. Considerando a última avaliação, a densidade encontrada foi de 2,2 indivíduos.m ${ }^{-2}$. A espécie dominante foi Leandra sp, com densidade relativa de $70 \%$. Houve incremento no número total de indivíduos de $100 \%$ da primeira para a segunda avaliação e desta última para a terceira avaliação de $25 \%$ (Tabelas 2, 3).

Tabela 2. Espécies, famílias e número de indivíduos amostrados no levantamento de indivíduos jovens, no Parque Estadual do Jurupará, Ibiúna, São Paulo. A- faixa experimental no interior do cultivo de Citrus sp, B - faixa experimental na pastagem de 0-20 m de distância do remanescente florestal, C - faixa experimental na pastagem de 80-100 m do remanescente florestal

\begin{tabular}{llccc}
\hline & \multicolumn{3}{c}{$\mathrm{N}^{\circ}$ de indivíduos } \\
\multicolumn{1}{c}{ Espécies } & \multicolumn{1}{c}{ Famílias } & A & B & C \\
\hline Cabralea canjerana (Vell.) Mart. & Meliaceae & 2 & --- & --- \\
Citrus sp & Rutaceae & 1 & --- & --- \\
Clethra scabra Pers. & Clethraceae & 2 & --- & --- \\
Rapanea sp & Myrsinaceae & 2 & 1 & 1 \\
Alchorne triplinervia (Spreng.) Müll.Arg, & Euphorbiaceae & 1 & --- & --- \\
Leandra sp & Melastomataceae & 16 & 2 & 7 \\
Myrtaceae 1 & Myrtaceae & 1 & --- & --- \\
Rapanea sp & Myrsinaceae & 2 & --- & 1 \\
Miconia cabussu Hoehne & Melastomataceae & 2 & 1 & --- \\
Psidium guajava L. & Myrtaceae & --- & --- & 2 \\
Trema micrantha (L.) Blume & Ulmaceae & --- & 2 & --- \\
Total & - --- & 29 & 6 & 11 \\
\hline
\end{tabular}

A taxa de mortalidade foi de $9,09 \%$ na área de Citrus $s p$, observada entre a primeira e segunda avaliação, correspondente a, um indivíduo de Cabralea canjerana, que desapareceu. $\mathrm{Na}$ pastagem de 0-20 m de distância do remanescente florestal, a taxa de mortalidade foi de 
16,67\%, com um indivíduo dee Rapanea sp entre a segunda e terceira avaliação. Na faixa experimental na pastagem de $80-100 \mathrm{~m}$ a taxa foi de $25 \%$, correspondendo a um indivíduo de Vernonia sp da primeira para a segunda avaliação e um indivíduo deRapanea sp da segunda para a terceira avaliação (Tabela 3).

Tabela 3. Espécies, número de indivíduos amostrados no levantamento de indivíduos jovens em cada avaliação, no Parque Estadual do Jurupará, Ibiúna, São Paulo. A faixa experimental na área de Citrus sp, B - faixa experimental na pastagem de 0-20 m de distância do remanescente florestal, $\mathrm{C}$ - faixa experimental na pastagem de 80-100 $\mathrm{m}$ do remanescente florestal. $\mathrm{J}=$ janeiro/2001, $\mathrm{A}=$ agosto/2001 e $\mathrm{F}=$ fevereiro/2002.

\begin{tabular}{lccccccccc}
\hline \multicolumn{1}{c}{ Espécies } & \multicolumn{3}{c}{ A } & & \multicolumn{3}{c}{ B } & \multicolumn{3}{c}{ C } \\
& J & A & F & J & A & F & J & A & F \\
\hline Cabralea canjerana (Vell.) Mart. & 2 & 1 & 2 & 0 & 0 & 0 & 0 & 0 & 0 \\
Citrus sp & 0 & 1 & 1 & 0 & 0 & 0 & 0 & 0 & 0 \\
Clethra scabra Pers. & 1 & 2 & 2 & 0 & 0 & 0 & 0 & 0 & 0 \\
Rapanea sp. & 2 & 2 & 2 & 0 & 1 & 0 & 0 & 1 & 0 \\
Alchorne triplinervia (Spreng.) Müll.Arg, & 0 & 0 & 1 & 0 & 0 & 0 & 0 & 0 & 0 \\
Leandra sp & 4 & 11 & 16 & 1 & 2 & 2 & 1 & 6 & 7 \\
Myrtaceae 1 & 0 & 0 & 1 & 0 & 0 & 0 & 0 & 0 & 0 \\
Rapanea sp. & 2 & 2 & 2 & 0 & 0 & 0 & 0 & 1 & 0 \\
Miconia cabussu Hoehne & 2 & 2 & 2 & 0 & 1 & 1 & 0 & 0 & 0 \\
Psidium guajava L. & 0 & 0 & 0 & 0 & 0 & 0 & 2 & 1 & 2 \\
Trema micrantha (L.) Blume & 0 & 0 & 0 & 1 & 2 & 2 & 0 & 0 & 0 \\
Total & 13 & 21 & 29 & 2 & 6 & 5 & 3 & 9 & 9 \\
\hline
\end{tabular}

No levantamento de indivíduos jovens regenerantes, do total de espécies amostradas, 95,5\% apresentaram síndrome de dispersão zoocórica e apenas 4,5\% anemocórica. Na área de Citrus sp, 93,1\% das espécies amostradas apresentaram síndrome de dispersão zoocórica e 6,9\% apresentaram síndrome de dispersão anemocórica. Na pastagem nas diferentes distâncias, 100\% das espécies amostradas apresentaram síndrome de dispersão zoocórica. 
Considerando o grupo ecológico, 54,54\% foram caracterizadas como pioneiras, 18,18\% características de subosque, 9,09\% secundárias iniciais, 9,09\% secundárias tardias, 9,09\% não foramclassificadas (Tabela 4).

Tabela 4. Espécies, grupo ecológico, síndrome de dispersão e forma de vida das espécies amostradas a partir do levantamento de indivíduos jovens, no Parque Estadual do Jurupará, Ibiúna, São Paulo. Grupos ecológicos: pio = pioneira, sb = característica do subosque, $\mathrm{si}=$ secundária inicial, st = secundária tardia; síndrome de dispersão: zoo = zoocórica, anem $=$ anemocóric, auto = autocórica; forma de vida: arv = árvore, arb $=$ arbusto, $\mathrm{nc}=$ não classificada.

\begin{tabular}{lccc}
\hline \multicolumn{1}{c}{ Espécies } & $\begin{array}{c}\text { Grupo } \\
\text { ecológico }\end{array}$ & $\begin{array}{c}\text { Sindrome de } \\
\text { dispersão }\end{array}$ & $\begin{array}{c}\text { Forma de } \\
\text { vida }\end{array}$ \\
\hline Alchornea triplinervia(Spreng.) Müll.Arg, & pio & zoo & arv \\
Cabralea canjarana (Vell.) Mart. & $\mathrm{st}$ & zoo & arv \\
Citrus sp (L.) Burm.f. & $\mathrm{sb}$ & zoo & arb \\
Clethra scabra Pers. & $\mathrm{si}$ & anem & arv \\
Leandra sp & $\mathrm{sb}$ & zoO & arb \\
Miconia cabussu Hoehne & pio & zoO & arv \\
Myrtaceae 1 & nc & zoO & arv \\
Psidium guajava L. & pio & zoO & arb \\
Rapanea sp & pio & zoO & arv \\
Trema micrantha (L.) Blume & pio & zoO & arv \\
\hline
\end{tabular}

\subsection{Discussão}

O banco de sementes apresentou um baixo número de sementes germinadas (8.754 sementes) nas duas avaliações realizadas (janeiro/2001 e agosto/2001) como também apresentou baixa densidade de sementes germinadas nas duas épocas de amostragem (1.502,22 sem.m ${ }^{-2}$ - janeiro/2001 e 1610,31 sem.m - agosto/2001), comparando-os com valores encontrados para outras áreas perturbadas. Baider (1994), ao avaliar a composição do banco de sementes da floresta Atlântica, verificou uma densidade de $11.028 \mathrm{sem} . \mathrm{m}^{-2} \mathrm{em}$ área submetida a corte raso e abandonada há cinco anos; $4.644 \mathrm{sem} . \mathrm{m}^{-2}$ em área também submetida a corte raso e abandonada há 18 anos; 5.100 sem. $\mathrm{m}^{-2}$ em área submetida ao mesmo tipo de perturbação e 
abandonada há 27 anos. As baixas densidades encontradas para áreas perturbadas nesse trabalho podem ser devidas ao histórico de perturbação da área, classificado como de uso moderado a leve (Uhl, 1988), com corte raso seguido de queima e introdução de espécies exóticas, sendo que na pastagem o uso foi mais intensivo (utilização de máquinas), o que pode ter influenciado na eliminação de espécies do banco e impedido a incorporação de novas sementes ao solo em consequiência da compactação do mesmo.

No entanto, ao comparar os valores de densidade obtidos com os valores encontrados para as florestas tropicais maduras (em média menos de 500 sem.m²) (Garwood, 1989), a densidade encontrada pode ser considerada elevada.

Geralmente, em áreas agropastoris abandonadas é observado um predomínio de espécies herbáceas no banco de sementes (6 a 100\%, em média 75\%) (Garwood, 1989). Nesse trabalho, as espécies herbáceas foram responsáveis por $99,95 \%$ das sementes em germinadas do solo coletado em janeiro/2001 e 99,70\% do solo coletado em agosto/2001. Apenas cinco espécies arbóreas germinaram nas três situações: Trema micrantha (7,47 sem.m $\left.{ }^{-2}\right)$, Bacharis dracunculifolia. (1,07 sem. $\left.\mathrm{m}^{-2}\right)$, e Senna multijuga (5,33 sem. $\left.\mathrm{m}^{-2}\right)$, Alchornea triplinervia (1,07 sem. $\left.\mathrm{m}^{-2}\right)$, Myrcia crassifolia $\left(1,07 \mathrm{sem} . \mathrm{m}^{-2}\right)$ com baixas densidades.

Na área de Citrus sp foi observada uma densidade de $1.731,2$ sem.m ${ }^{-2}$ no banco de sementes coletado em janeiro/2001 e 1.587,2 sem.m ${ }^{-2}$ no banco de sementes coletado em agosto/2001, ocorrendo uma predominância de sementes germinadas de origem alóctone (90,4\% - janeiro/2001, 78,1\% - agosto/2001). Apenas a espécie herbácea Commelina sp foi observada naturalmente nesta área. Na pastagem mais próxima do remanescente florestal foi encontrada uma densidade de 1.086,93 sem.m ${ }^{-2}$ em janeiro/2001 e 1.889,07 sem.m em $^{-2}$ agosto/2001, com 100\% das espécies germinadas em janeiro/2001 e 99,95\% das espécies germinadas em agosto/2001 de origem autóctone. Na pastagem mais distante do remanescente florestal foi encontrada uma densidade de 1.636,18 sem.m ${ }^{-2}$ em janeiro/2001 e 1.354,67 sem.m ${ }^{-2}$ em agosto/2001, com 100\% das espécies germinadas em janeiro/2001 e 99,93\% das espécies germinadas em agosto/2001 de origem autóctone. 
As espécies de origem alóctone germinadas no banco de sementes na área de Citrus $s p$ foram: Alchornea triplinervia, Myrcia crassifolia, Bacharis dracunculifolia,. Considerando que duas primeiras espécies apresentam sementes zoocóricas, os propágulos provavelmente foram transportados por pássaros até a área de Citrus sp que possui em seu subosque arbustos com frutos atrativos da fauna (Leandra sp), já a espécie Bacharis dracunculifolia deve ter chegado até a área por dispersão anemocórica. Na pastagem foi observada uma única espécie de origem alóctone, Trema micrantha, na faixa experimental mais próxima do remanescente florestal, apresentando representantes adultos na borda do remanescente florestal, o que pode ter facilitado a dispersão das suas sementes para a pastagem.

As diferenças na composição do banco de sementes entre Citrus sp e pastagem referem-se à presença de apenas três espécies arbustivo-arbóreas na área de Citrus sp com densidades muito baixas: Myrcia crassifolia $\left(1,07\right.$ sem. $\left.\mathrm{m}^{-2}\right)$, Bacharis dracunculifolia $(1,07$ sem. $\left.\mathrm{m}^{-2}\right)$ e Alchornea triplinervia $\left(1,07 \mathrm{sem} . \mathrm{m}^{-2}\right)$. Desta forma, as características da matriz degradada não está definindo a composição do banco de sementes, rejeitando a hipótese inicial deste trabalho, já que não foram observadas diferenças significativas entre a área de Citrus sp e pastagem.

A composição do banco de sementes na pastagem apresentou, nas duas distâncias do remanescente florestal, predominância de espécies herbáceas, na faixa próxima do remanescente florestal $(99,7 \%)$ e na faixa mais distante do remanescente florestal $(99,9 \%)$. Apenas duas espécies arbustivo-arbóreas germinaram com densidades muito baixas, na faixa mais próxima: Trema micrantha $\left(6,4\right.$ sem. $\left.\mathrm{m}^{-2}\right)$ e Senna multijuga $\left(3,2 \mathrm{sem} . \mathrm{m}^{-2}\right)$; na faixa mais distante apenas a espécie Senna multijuga germinou com densidade de 1,07 sem.m ${ }^{-2}$. As diferenças encontradas no banco de sementes para as diferentes distâncias do remanescente florestal não são significativas, rejeitando a hipótese de que a composição do banco de sementes está inversamente relacionado com a distância do remanescente florestal.

A situação de dominância das espécies herbáceas, muitas delas ruderais, é comum em trabalhos com o banco de sementes de comunidades fragmentadas ou cercadas de vegetação não natural (Hopkins et al. 1990). Alguns fatores como mecanismos eficientes de dispersão, 
tamanho e dormência destas espécies colaboram para tal padrão (Garwood, 1989, Hopkins e Graham, 1984; Vázquez-Yanes \& Orozco-Segovia, 1987).

As sementes das espécies amostradas no banco de sementes, predominantemente herbáceas, eram todas pequenas, ou seja, com diâmetro inferior a cinco milímetros. Espécies que ocorrem enterradas no banco de sementes, via de regra, são pequenas. Entre as vantagens adaptativas comumente conferidas a essa característica estão a menor pressão de predação e a maior facilidade de incorporação ao solo (Orozco-Segovia, et al. 1993).

A ausência de sementes maiores que cinco milímetros no banco de sementes reflete a pequena viabilidade das sementes grandes, além de outros fatores limitantes, como a pressão de predação acentuada, a maior vulnerabilidade ao ataque de fungos, além da maior dificuldade física para o seu enterramento (Orozco-Segovia et al., 1993)

As espécies da floresta são raramente encontradas na pastagem recentemente abandonada e as sementes da maioria das espécies da Floresta Tropical perdem rapidamente a viabilidade (Garwood, 1989; Vázquez-Yanes \& Orozco-Segovia, 1993), o que justifica o fato de ter sido encontrado praticamente apenas espécies herbáceas no banco de sementes. Entretanto, a sucessão nas pastagens abandonadas é dependente das sementes da floresta dispersas recentemente. Estudos demonstraram claramente que a falta de dispersão de sementes é um dos fatores que mais limitam a regeneração em pastagens abandonadas (Willson \& Crome, 1989; Aide \& Cavelier, 1994; Vieira et al., 1994).

No levantamento do estrato de regeneração obteve-se poucos indivíduos jovens, fato que pode estar relacionado à seca atípica que ocorreu durante o período de acompanhamento dos indivíduos jovens, como também às características da área com um histórico de dominância de gramíneas altamente agressivas (Lima, 1993).

A densidade do estrato de regeneração encontrado neste trabalho foi de 2.93 indivíduos. $\mathrm{m}^{-2}$ considerando as três avaliações realizadas, onde foram amostrados 44 indivíduos, pertencentes a 11 espécies. Considerando o grupo ecológico das 11 espécies amostradas seis são pioneiras, duas são de subosque, uma secundária inicial, uma secundária tardia e uma não caracterizada. 
Na área de Citrus sp foram amostrados 29 indivíduos $\left(5,8\right.$ ind. $\left.\mathrm{m}^{-2}\right)$ e nove espécies, onde cinco espécies eram pioneiras, duas do subosque, uma secundária inicial, uma secundária tardia e uma sem caracterização. $\mathrm{Na}$ pastagem próxima ao remanescente florestal foram amostrados seis indivíduos $\left(1,2\right.$ ind. $\left.\mathrm{m}^{-2}\right)$ e quatro espécies, sendo três pioneiras e uma de subosque. Na pastagem mais distante do remanescente florestal foram amostrados 11 indivíduos $\left(2,2\right.$ ind. $\left.\mathrm{m}^{-2}\right)$ e quatro espécies, sendo três pioneiras e uma do subosque.

Na área de Citrus sp foi encontrada maior proporção de espécies características de subosque $(58,62 \%)$ devido provavelmente à condição de sombreamento da área, desfavorável ao desenvolvimento de espécies pioneiras e secundárias iniciais. No interior da pastagem a 0-20 m de distância do remanescente florestal, foi encontrada maior proporção de espécies pioneiras $(66,66 \%)$ em conseqüência, possivelmente, das condições de alta luminosidade. Na faixa experimental no interior da pastagem de 80-100 m foi observado maior proporção de espécies características de subosque $(63,63 \%)$, que pode ter sido devido ao sombreamento ocasionado pela grande densidade de espécies gramíneas, em especial Urochloa decumbens. Este resultado também foi obtido por Holl (1999), em que a germinação das sementes de espécies arbóreas localizadas na pastagem debaixo de gramíneas foi mais alta que em áreas sem vegetação, possivelmente devido à redução da temperatura e dessecação da semente, particularmente em períodos secos.

As características da matriz degradada influenciaram na densidade de indivíduos jovens amostrados e na sua composição, que foi maior na área de Citrus sp do que na pastagem, indicando que as espécies presentes na área de Citrus sp podem estar estimulando a regeneração da área. No entanto, este resultado deve ser considerado com ressalvas já que a amostragem obtida foi muito pequena.

Considerando a densidade de indivíduos jovens na pastagem, embora a amostragem obtida nesta área tenha sido muito pequena, esta não diminui conforme o aumento da distância do remanescente florestal, indicando que a distância do remanescente florestal não foi o principal fator limitante da regeneração da pastagem. Pesquisas na Floresta Tropical têm sugerido que altas temperaturas e baixa disponibilidade de umidade nas pastagens pode resultar em stress 
hídrico para as plantas (Nepstad et al., 1991; 1996) e podem limitar o estabelecimento e sobrevivência de plântulas (Uhl, 1987), como também a presença de gramíneas e a sua rápida colonização e crescimento em pastagens abandonadas parece ser o maior fator inibidor do estabelecimento da floresta secundária (Aide et al., 1995).

Acima e abaixo da terra, a competição com gramíneas na pastagem tem sido sugerida como o fator que mais limita o crescimento de certas espécies de plantas nas pastagens tropicais (Nepstad et al., 1991, Guariguata et al., 1995; Sun \& Dickinson, 1996). Entretanto, outros estudos (Aide \& Cavelier, 1994) sugerem que as gramíneas na pastagem tem um efeito complexo na recuperação, já que os solos da Floresta Tropical são extremamente variáveis com respeito a constituição mineral e histórico de degradação (Sanchez, 1976).

Outro fator que pode alterar as taxas de germinação e o estabelecimento em áreas de pastagens é a compactação do solo, que afeta o crescimento da raiz, as trocas gasosas e as taxas de infiltração (Trouse \& Humbert, 1961).

A síndrome de dispersão mais freqüente entre as espécies em regeneração encontradas neste trabalho foi a zoocoria $(95,65 \%)$, indicando que a inatividade da fauna em campos abertos pode ser um fator importante na limitação da recuperação de pastagens tropicais.

Duncan et al. (1999) verificou, em um estudo no Kibale, leste da África, que áreas degradadas por atividades agropastoris abandonadas avançam lentamente. $\mathrm{O}$ recrutamento de plantas em áreas degradadas pode incluir poucas árvores e, provavelmente, áreas limitadas sob médias e grandes árvores. Áreas ao redor destas árvores podem ser dominadas por uma alta densidade de gramíneas, que podem impedir o estabelecimento das poucas sementes que chegam à área. Além disso, durante os períodos secos, estas pastagens freqüentemente queimam, eliminando muitas árvores colonizadoras e perpetuando a dominância das gramíneas. No Kibale, as pastagens ainda persistem depois de 100 anos de abandono. 


\section{Conclusões}

A composição do banco de sementes amostrado mostrou-se praticamente uniforme nas duas situações estudadas. Desta foma, não foram observadas diferenças significativas na composição do banco de sementes entre a área de Citrus $s p$ e a pastagem, rejeitando a hipótese de que a composição do banco de sementes é definida pelas características vegetacionais da matriz degradada.

$\mathrm{Na}$ pastagem para as duas distâncias estudadas, não foram observadas diferenças significativas na composição do banco de sementes, rejeitando a hipótese de que a composição do banco de sementes está inversamente relacionado com a distância do remanescente florestal.

A composição do banco de sementes amostrado não possui potencial para promover a regeneração natural na pastagem nem, provavelmente, promoverá a sucessão com o aumento na riqueza de espécies no interior do cultivo de Citrus sp, já que é composto predominantemente por espécies herbáceas.

No levantamento dos indivíduos jovens regenerantes, a amostragem obtida foi insuficiente, impossibilitando a determinação de padrões. Contudo, foram observadas algumas tendências: foi amostrada maior densidade de indivíduos jovens regenerantes na área de Citrus $s p$, podendo este fato ser relacionado às características da matriz degradada; na pastagem, a densidade de indivíduos jovens regenerantes não pode ser inversamente relacionada com a distância do remanescente florestal.

Nesse levantamento foi observada a predominância de espécies pioneiras com síndrome de dispersão zoocórica.

Apenas duas espécies foram encontradas concomitantemente no banco de sementes e no levantamento de indivíduos jovens: Trema micrantha e Alchornea triplinervia. 


\section{CONCLUSÕES GERAIS}

Diferenças significativas entre as distâncias do remanescente florestal não foram encontradas, rejeitando, desta forma, a hipótese de que à distância do remanescente florestal e a resiliência de áreas degradadas estão inversamente relacionadas para os três aspectos de dinâmica florestal analisados.

A partir da análise destes aspectos, é possível inferir que a pastagem estudada é incapaz de regenar naturalmente a curto prazo. A área com o cultivo de Citrus sp dificilmente atingirá a diversidade de uma floresta madura.

A distância do remanescente florestal não é o maior fator limitante da regeneração natural da área estudada; devem existir outros fatores que podem estar determinando a velocidade da regeneração natural, como a falta de dispersores, competição com espécies herbáceas típicas de pastagens e invasoras, altas temperaturas e baixa disponibilidade de água.

Para acelerar a regeneração da área de estudo seria necessário promover o manejo da área com técnicas que combatam a dominância das gramíneas e atraiam a fauna dispersora de sementes. 
ANEXOS 


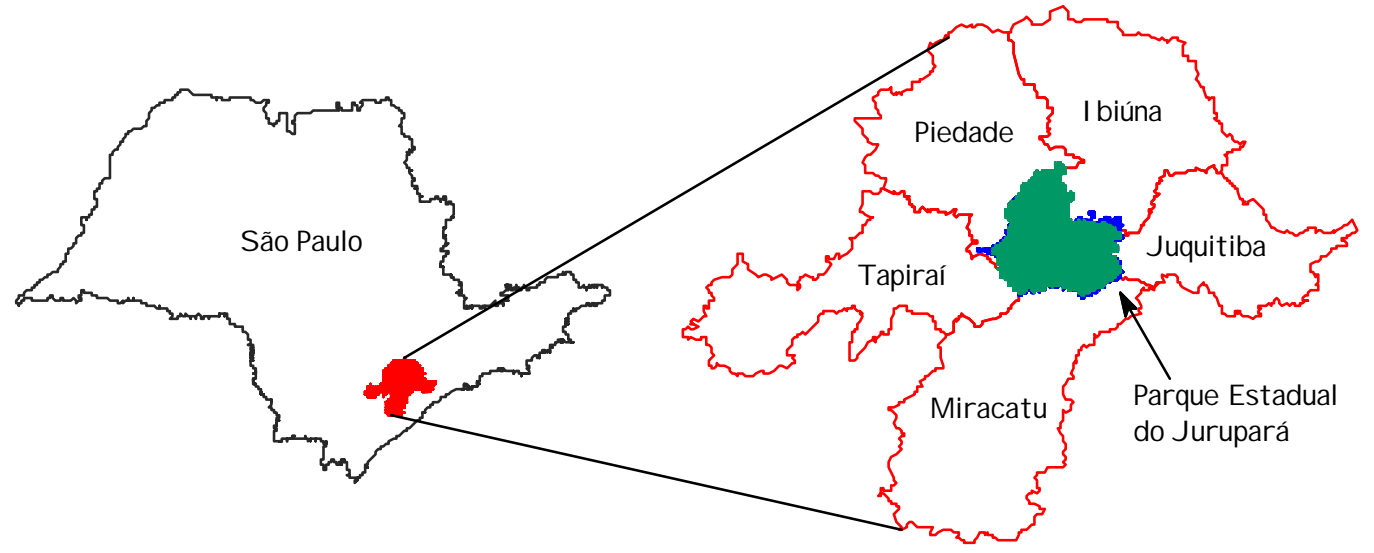

Figura 1 - Mapa esquemático com a localização do Parque Estadual do Jurupará, município de Ibiúna, São Paulo. 
ANEXO B

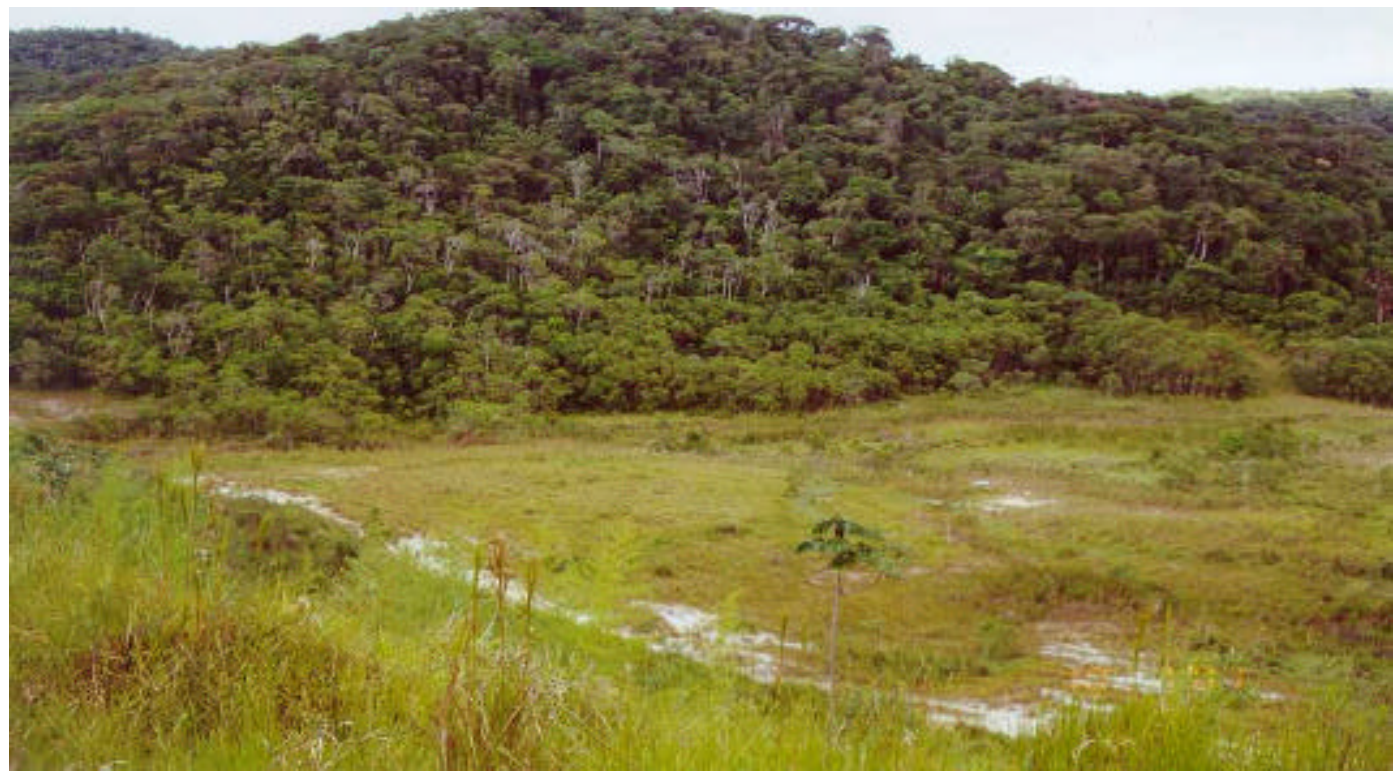

Figura 1 - Vista geral da área experimental na pastagem no interior do Parque Estadual do Jurupará, Ibiúna, São Paulo, observar ao fundo o remanescente florestal.

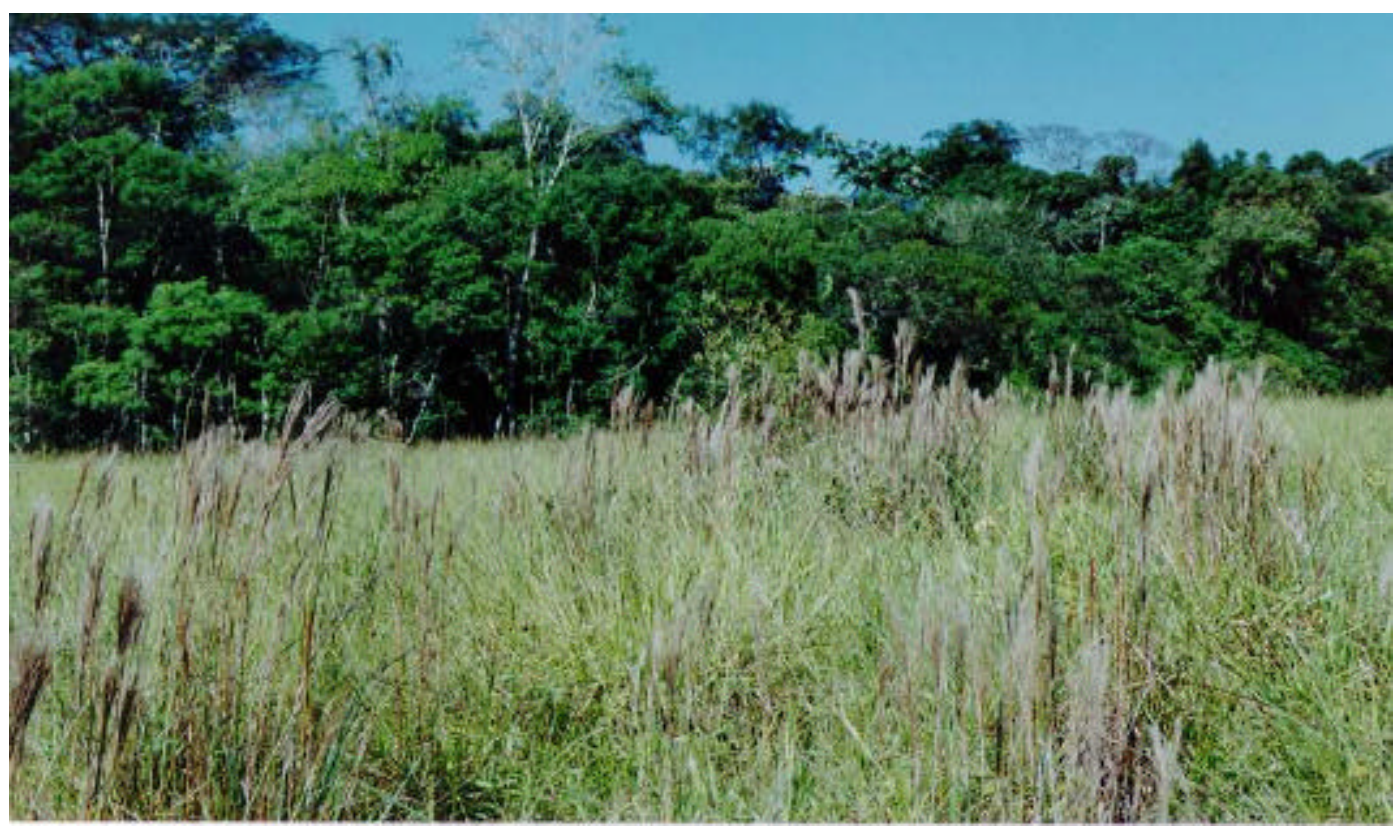

Figura 2 - Área experimental na pastagem no interior do Parque Estadual do Jurupará,

Ibiúna, São Paulo, observar a dominância de gramíneas. 
ANEXO C

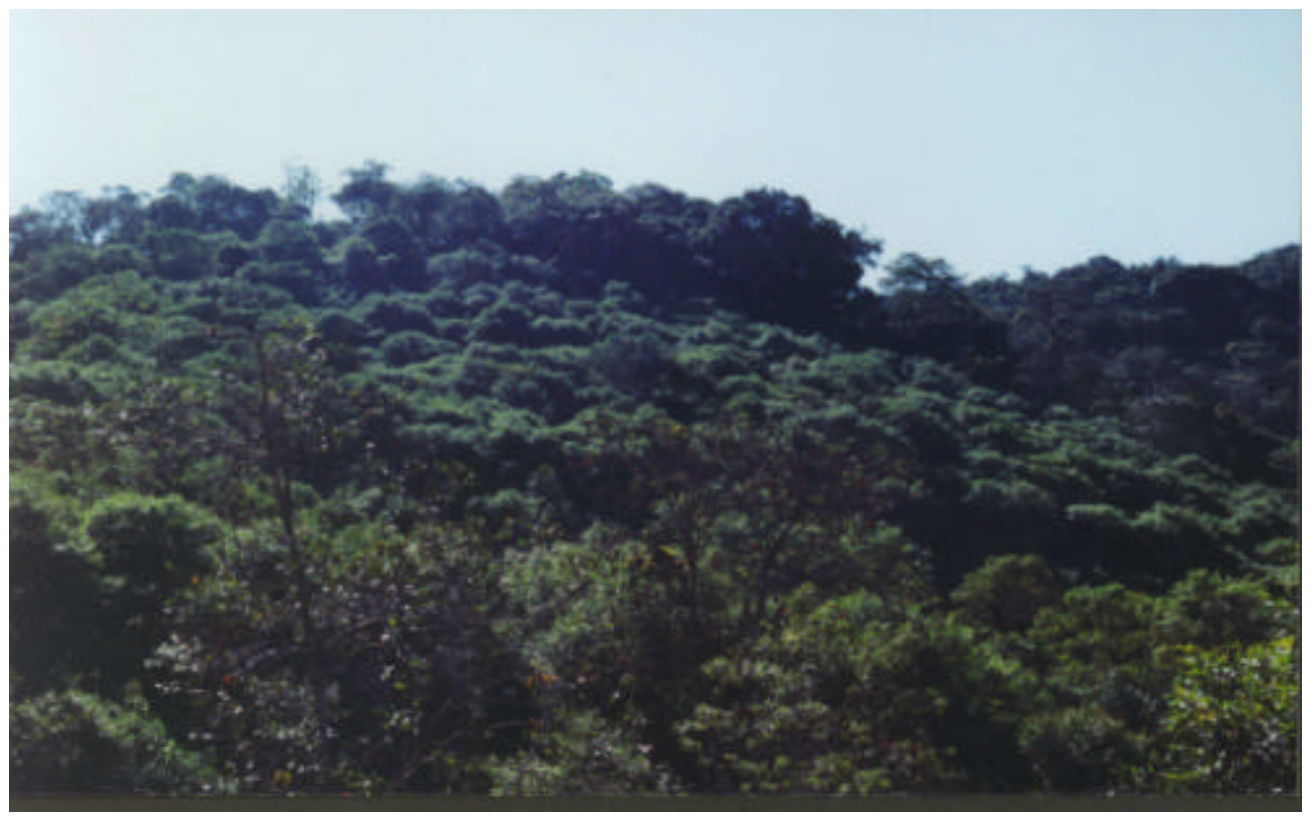

Figura 3 - Vista geral externa da área experimental no interior do cultivo de Citrus sp, correspondente ao local com o dossel mais baixo, no interior do Parque Estadual do Jurupará, Ibiúna, São Paulo.

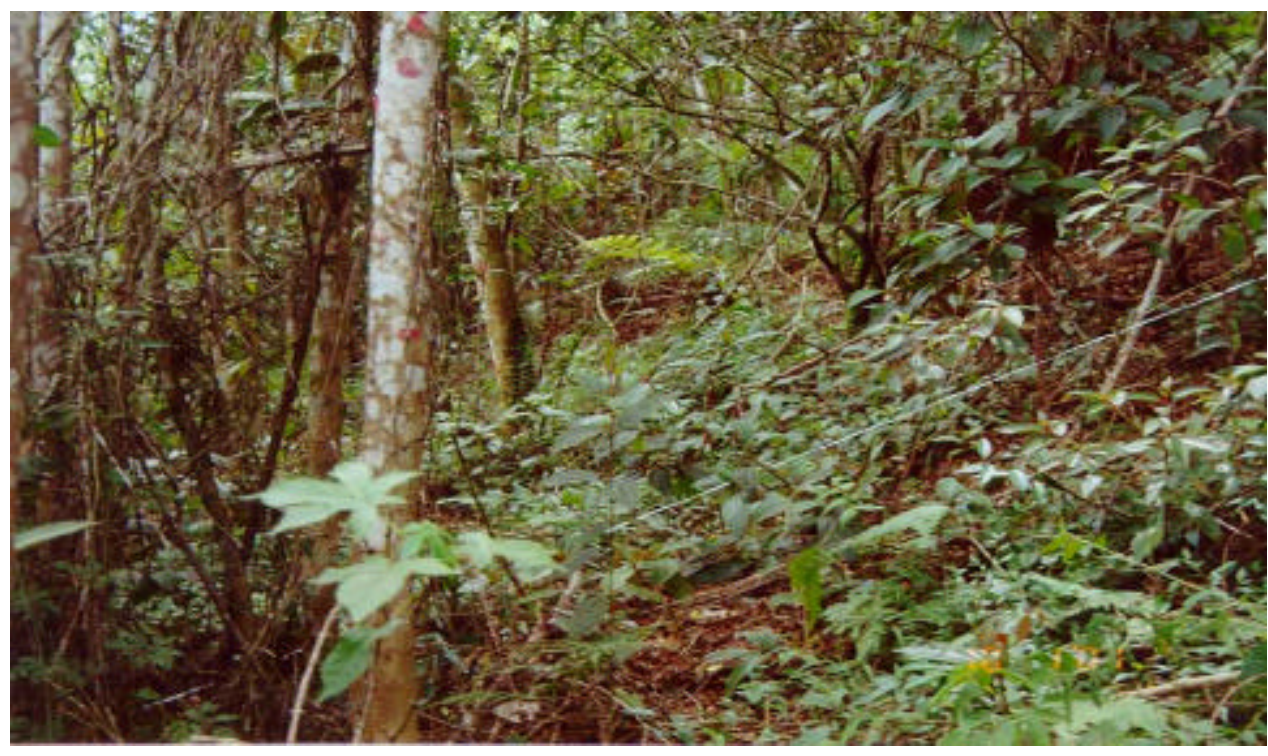

Figura 4 - Vista geral da faixa experimental no interior do cultivo de Citrus sp no interior do Parque Estadual do Jurupará, Ibiúna, São Paulo. Observar regeneração no subosque. 


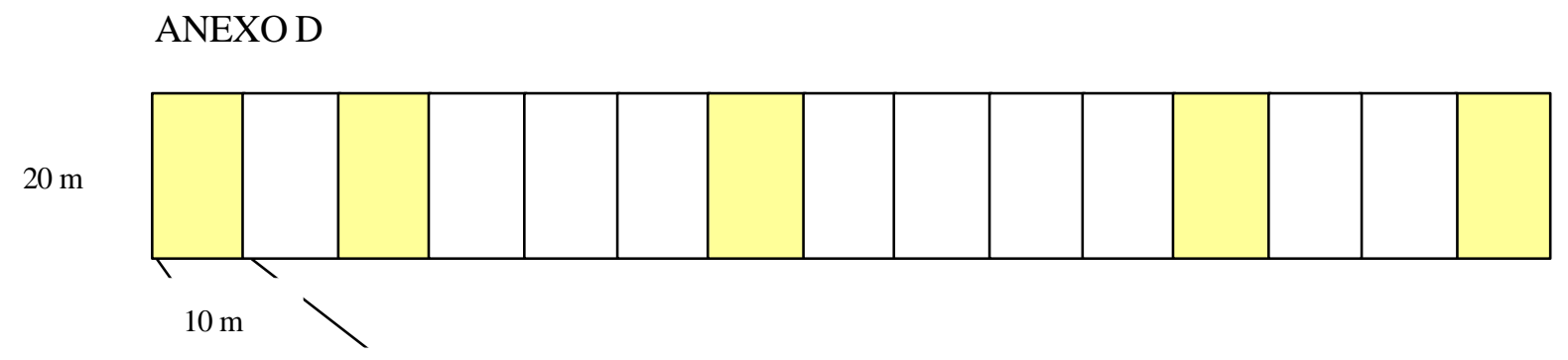

Figura 5a- Demonstração da distribuição das parcelas em uma das 3 faixas experimentais.

Cada faixa contendo 15 parcelas de $10 \times 20$ m, das quais foram sorteadas 5 (em amarelo), instaladas no interior do Paroue Fstadual do Jurunará.

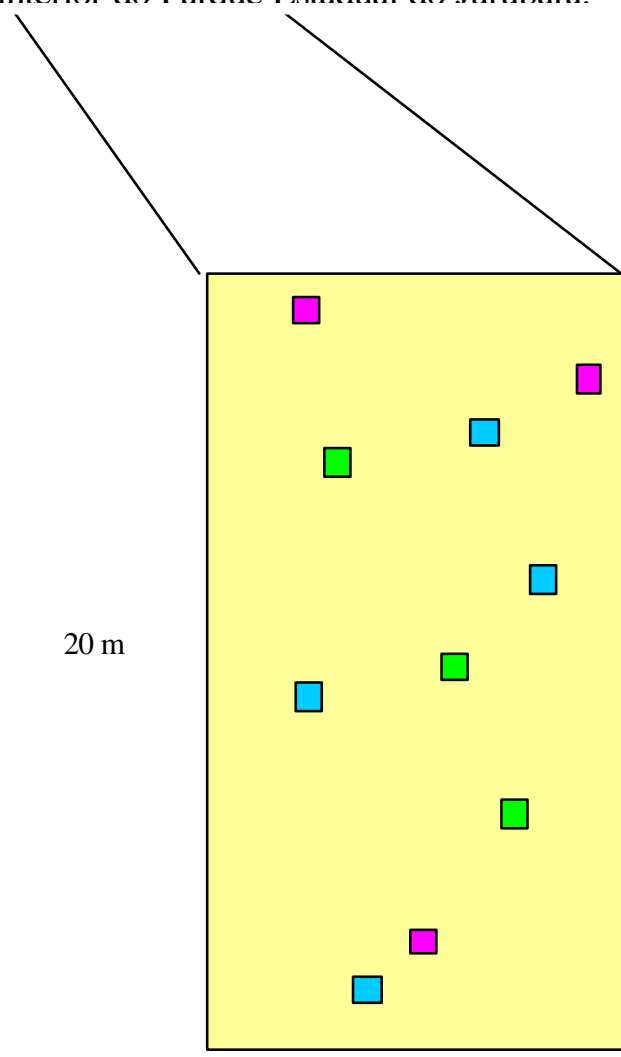

Legenda

$10 \mathrm{~m}$

Figura 5b - Demonstração da parcela de $20 \times 10 \mathrm{~m}$ com as sub-parcelas de 0,5 X 0,5 m no seu interior, distribuídas aleatoriamente. 


\section{RFERÊNCIAS BIBLIOGRÁFICAS}

AIDE, T.M.; CAVELIER, J. Barriers to tropical lowland forest restoration in the Sierra Nevada de Santa Marta, Colombia. Restoration Ecology, v.2, p.219-229, 1994.

AIDE, T.M.; ZIMMERMAN, J.K; HERRERA, L. ROSARIO, M.; SERRANO, M. Forest recovery in abandoned tropical pastures in Puerto Rico. Forest Ecology and Management, v.77, p.77-86, 1995.

ALBUQUERQUE, G.B. Floresta Nacional de Ipanema: caracterização da vegetação em dois trechos distintos do morro de Araçoiaba, Iperó (SP). Piracicaba, 1999. 186 p. Dissertação (Mestrado) - Escola Superior de Agricultura "Luiz de Queiroz”, Universidade de São Paulo.

ALENCAR, R.M.A.; NOGUEIRA, J.C.B.; EMMERICH, W. Terras do $2^{\circ}$ Perímetro de São Roque e suas características fisiográficas. Boletim Técnico do Instituto Florestal, v.20, p.1-3, 1976.

ALVAREZ-BUYLLA, E.; MARTÍNEZ-RAMOS, R. Seed bank versus seed rain in the regeneration of a tropical pioneer tree. Oecologia, v.84, p.314-325, 1990.

AMELUNG, T.; DIEHL, M. Deforestation of tropical rain-forests: economic causes and impact on development. Tübingen: Mohr, 1992. 60p. 
AOKI, H.; SARAIVA, I.R. Análise temporal da cobertura vegetal da Reserva Florestal de Ibiúna através de fotografias aéreas. In: CONGRESSO NACIONAL SOBRE ESSÊNCIAS NATIVAS, Campos de Jordão, 1982. Anais. São Paulo: Instituto Florestal, 1982. v.3, p.1806-1810.

ARAGAKI, S.; MANTOVANI, W. Caracterização do clima e da vegetação de remanescente florestal no planalto paulistano (SP). In: SIMPÓSIO DE ECOSSISTEMAS BRASILEIROS 4., Águas de Lindóia, 1998. Anais. São Paulo: ACIESP, 1998. v.2, p. 25-35.

ARONSON, J.; FlORET, C.; LE FLOC'H, E.; OVALLE, C.; PONTANIER, R. Restauration et réhabilitation des écosystèmes dégradés em zones arides et semi-arides. Vocabulaire et les concepts. In: PONTANIER, R.; HIRL, A.; ARONSON, J.; LE FLOC'H, E. L'Homme peut - il refaire ce qu'il a défait?, Paris: John Libbey Eurotext, 1995. p.11-29.

AUGSPURGER, C.K. Seed dispersal of tropical tree species: interation Platypodium elegan and escape of its seedlings from fungal pathogens. Journal of Ecology, v.71, n.3, p.759$771,1983$.

BAIDER, C.; TABARELLI, M.; MANTOVANI, W. O banco de sementes de um trecho de floresta Atlântica Montana (São Paulo, Brasil). Revista Brasileira de Biologia, v.59, n.2, p.319-328, 1999.

BAIDER, C. O banco de sementes e de plântulas na sucessão da Mata Atlântica. São Paulo, 1994. 137p. Dissertação (Mestrado) - Instituto de Biociências, Universidade de São Paulo. 
BROKAW, N.V.L. Treefalls, regrowth, and community structure in tropical forests. In: PICKETT, S.T.A.; WHITE, P.S (Ed.). The ecology of natural disturbance and patch dynamics. San Diego: Academic Press, 1985. p.53-69.

BUSCHBACHER, R.; UHL, C.; SERRÃO, E.A.S. Abandoned pastures in eastern Amazonia II. Nutrient stocks in the soil and vegetation. Journal of Ecology, v.76, p.682-699, 1988.

CARDOSO-LEITE, E. Ecologia de um fragmento florestal em São Roque, SP: florística, fitossociologia e silvigênese. Piracicaba, 1995. 235 p. Dissertação (Mestrado) - Escola Superior de Agricultura “Luiz de Queiroz”, Universidade de São Paulo.

CAVELIER, J.; AIDE, T.M.; SANTOS, C.; EUSSE, A.M.; DUPUY, J.M. The savannization of moist forests in the Sierra Nevada de Santa Marta, Colombia. Journal of Biogeography, v.25, p.901-912, 1998.

DALLING, J.W.; SWAINE, M.D.; GARWOOD, N.C. Soil seed bank community dynamics in seasonally moist lowland tropical forest, Panama. Journal of Tropical Ecology, v.13, p.659-680, 1997.

DUNCAN, R.S.; CHAPMAN, C.A. Seed dispersal and potential forest succession in abandoned agriculture in Tropical Africa. Ecological Applications, v.9, n.3, p.998-1008, 1999.

ESTEVES, R.; PASTORE, J.A.; FRANCO, G.A.D.C.; AGUIAR, O.T.; BAITELLO, J.B. Parque Estadual de Jurupará regiões de Ibiúna e Miracatú relação das espécies nativas e seus respectivos hábitos. São Paulo: Instituto Florestal, 1995, 6p. (Relatório Técnico do Instituto Florestal do Estado de São Paulo). 
FAO. State of the world's forests. Rome, 1997. 66p.

FENNER, M. Susceptibility to shade in seedlings of colonising and closed turf species. New Phytology, v.81, n.5, p.739-744, 1978.

FEARNSIDE, P.M. Deforestation in Brazilian Amazonia: the effect of population and land tenure. Ambio, v.2, p.537-545, 1993.

FERNANDES, D.N.; SANFORD, R.L Effects of recent land-use practices on soil nutrients and succession under tropical wet forest in Costa Rica. Conservation Biology, v.9, p.915922, 1995.

FETCHER, N.; OBERBAUER, S.F.; ROJAS, G.; STRAIN, B.R. Efectos del régimen de luz sobre la fotossíntesis y el crescimiento en plántulas de árboles de un bosque lluioso tropical de Costa Rica. Revista de Biologia Tropical, v.35, suppl.1, p.97-110, 1987.

FOSTER, R.B. The seazonal rythm of fruitfall on Barro Colorado Island.. In LEIGH, E.G.; WINDSOR, D.M. (Ed.). The ecology of a tropical forest. Seasonal rytms and longterm changes. Washington: Smithsonian Institution Press, 1985. p.151-172.

GARWOOD, N.C. Tropical soil seed banks: a review. In: LECK, M., PARKER, V.; SIMPSON, R(Ed.). Ecology of soil seed banks. San Diego: Academic Press, 1989. p.149-209.

GENTRY, A.H. Changes in plant community diversity and floristic composition on environmental and geographical gradientes. Annals of the Missouri Botanical Garden, v.75, p.1-34, 1988. 
GREENE, D.F.; JOHNSON, A. Wind dispersal of seeds from a forest into a clearing. Ecology, v.77, p.595-609, 1996.

GRIME, J.P. Plant strategies and vegetation process. 4. ed. Chichester: John Wiley, 1986. $222 p$.

GROMBONE-GUARITINI, M.T. Dinâmica de uma Florestal Estacional Semidecidual: o banco, a chuva de sementes e o estrato de regeneração. Campinas, 1999, 150p. Tese (Doutorado) - Universidade Estadual de Campinas.

GUARIGUATA, M.R.; RHEINGANS, R.; MONTAGNINI, F. Early woody invasion under tree plantations in Costa Rica: implications for forest restoration. Restoration Ecology, v.3, p.252-260, 1995.

GUEVARA, S.S.; GÓMEZ-POMPA, A. Seeds from surface soils in a tropical region of Veracruz, México. Journal of Arnold Arboretum, v.53, p.312-335, 1972.

HARPER, J.L. Population biology of plants. London: Academic Press, 1977. 892p.

HEERDT, G.N.J; VERWEIJ, G.L.; BAKKER, R.M.; BAKKER, J.P. An improved method for seed bank analysis: seedling emergence after removing the soil by sieving. Functional Ecology, v.10, p.144-151, 1996.

HOLL, K.D. Effects of above- and below-ground competiton of shrubs and grass on Callophylum brasiliense (Camb.) seedling growth in abandone tropical pasture. Forest Ecology and Management, v.109, p.187-195, 1998. 
HOLL, K.D. Factors limiting tropical rain forest regeneration in abandoned pasture: seed rain, seed germination, microclimate, and soil. Biotropica, v.31, n.2, p.229-242, 1999.

HOLL, K.D.; LULOW, M.E. Effects of species, habitat, and distance from edge on postdispersal seed predation in a tropical rainforest. Biotropica, v.29, p.459-468, 1997.

HOPKINS, M.S.; GRAHAM, A.W. Viable soil seed banks in disturbed lowland tropical rainforests in North Queensland, Australia. Australian Journal Ecology, v.9, p.71-79, 1984.

HOPKINS, M.S.; GRAHAM, A.W. The viable of seeds of rain forest species after experimental soil buried under tropical wet lowland forest in north-eastern, Australia. Melboure. Australian Journal Ecology, v.12, n.2, p.97-108, 1987.

HOPKINS, M.S.; TRACEY, J.G.; GRAHAM, A.W. The size and composition of soil seed banks in remnant patches of three structural rainforest types in North Queensland, Australia. Melbourne. Australian Journal of Ecology, v.15, p.43-50, 1990.

HOUGHTON, R.A. Global effects of deforestation. In: HOFFMAN, D.J.; RATTNER, B.A.; BURTON, G.A.; CAIRNS, J. (Ed.). Handbook of ecotoxicology. Florida: Lewis, 1995. p.492-508.

HOWE, H.F. Implications of seed dispersal by animals for tropical reserve management. Biology Conservation, v.30, p.261-281, 1984.

HOWE, H.F; SMALLWOOD, J. Ecology of seed dispersal. Annual Review of Ecology and Systematics, v.13, p. 201-228, 1982. 
HUTCHINGS, M.J. The struture of plant population. In: CRAWLEY, M.J. Plant ecology. 2. ed. Oxford: Blackwell Scientific, 1986. p.96-136.

JANZEN, D.H. Herbivores and the number of tree species in tropical forest. American Naturalist, v.104, n.940, p.501-528, 1970.

KÖPPEN, W. Climatologia: con un estudio de los climas de la tierra. Mexico: Fondo de Cultura Economica, 1948. 478p.

LASKA, M.S. Structure of understory shrub assemblages in adjacent secondary and old growth tropical wet forests, Costa Rica. Biotropica, n.29, p.29-37, 1997.

LEAN, J.; WARRILOW, D.A. Simulation of the regional impact of Amazon deforestation. Science, v.342, 411-413, 1989.

LEITE, A.M.C.; RANKIN, J.M.; LLERAS, E. Ecologia de plântulas de Pithecelobium racemosum Ducke. 2 - O comportamento populacional de plântulas. Acta Amazônica, v.12, n.3, p.529-548, 1982.

LIEBERMAN, D.; LIBERMAN, M. Forest tree growth and dynamics at La Selva, Costa Rica (1969-1982). Journal of Tropical Ecology, v.3, n.4, p.347-358, 1987.

LIMA, F.J. Controle químico do capim-braquiária (Brachiaria decumbens Stapf) na implatação de algumas gramíneas forrageiras.Piracicaba, 1993. 138p. Dissertação (Mestrado) - Escola Superior de Agricultura "Luiz de Queiroz", Universidade de São Paulo.

MILES, J. Vegetation dynamics. Cambridge:Chapman and Hall, 1979. 80p. 
MYSTER, R.W.; PICKETT, S.T.A. Dynamics of associations between plants in ten old fields during 31 years of succcession. Journal of Ecology, v.80, p.291-302, 1992.

NASCIMENTO, F.H.F. A sucessão secundária inicial na mata Atlântica, sobre a serra de Paranapiacaba, Ribeirão Grande, SP. São Paulo, 1994. 79p. Dissertação (Mestrado) Instituto de Biociências, Universidade de São Paulo.

NEPSTAD, D.C.; UHL, C.; PEREIRA, C.A.; SILVA, J. M.C do. Comparative study of tree establisment in abandoned pasture and mature forest of eastern Amazonia. Oikos, v.76, p.25-39, 1996.

NEPSTAD, D.C.; UHL, C.; SERRAO. Recuperation of a degraded Amazonian landscape: forest recovery and agricultural restoration. Ambio, v.20, p.248-255, 1991.

OlIVEIRA, J.B., CAMARGO, M.N., ROSSI, M.; CALDERANO FILHO, B. Mapa Pedológico do Estado de São Paulo. Campinas: IAG/EMBRAPA/CNPS, 1999.

OROZCO-SEGOVIA, A.; SANCHEZ-CORONADO, M.E.; VÁZQUEZ-YANES, C. Light enviroment and phytochrome - controlled germination in Piper auritum. Functional Ecology. v.7, n.5, p.585-590, 1993.

OSUNKJOVA, O.O.; ASH, J.E.; HOPKINS, M.S.;GRAHAM, A.W. Factors affecting survival of tree seedlings in North Queensland rainforests. Oecologia, v.91, p.569-578, 1992.

PICKETT, S.T.A.; COLLINS, S.L.; ARMESTO, J.J. Models, mechanisms, and pathways of succession. Botanical Review, v.53, p.335-371, 1987. 
PUTZ, F.E.; APPANAH, B. Buried seeds, newly dispersed seeds, and the dynamics of a lowland forest in Malaysia. Biotropica, v.19, p.326-339, 1987.

PUTZ, F.E. Treefall pits and mounds, buried seeds, and the importance of soil disturbance to pioneer trees on Barro Colorado Island, Panama. Ecology, v.64, n.5, p.1069-1074, 1983.

ROBERTS, H.A. Seed banks in soils. Advances in Applied Biology, v.6, p.1-45, 1981.

RODRIGUES, R.R.; GANDOLFI, S. Restauração de florestas tropicais: subsídios para uma definição metodológica e indicadores de avaliação e monitoramento. In: DIAS, L.E.; MELO, J.W.V. (Ed). Recuperação de Áreas Degradadas, Viçosa: Universidade Federal de Viçosa; Sociedade Brasileira de Recuperação de Áreas Degradadas, 1998. p. 203-215.

RODRIGUES, R.R.; GANDOLFI, S. Conceitos, tendências e ações para a recuperação de florestas ciliares. In: RODRIGUES, R.R.; LEITÃO FILHO, H.F. (Ed). Matas ciliares: conservação e recuperação, São Paulo: Universidade de São Paulo, 2000. p.235-248.

SANCHEZ, P.A. Properties and management of soils in the tropics. New York: John Wiley, 1976. 325p.

SHUKLA, J.; NOBRE, C.; SELLERS, P. Amazon deforestation and climate change. Science, v.247, p.1322-1325, 1990.

SILVA, J.M.C. do; UHL C.; MURRAY, G. Plant succession, landscape management, and the ecology of frugivorous birds in abandoned Amazonian pastures. Conservation Biology, v.10, p.491-503, 1996. 
SIMPSON, R.L.; LECK, M. A.; PARKER, V T. Seed banks: general concepts and methodological issues. In: LECK, M.A.; PARKER, V.T.; SIMPSON, R.L. Ecology of soil seed banks. San Diego: Academic Press, 1989. p. 3-7.

SMITH, A.P. Respuestas de hierbas del sotobosque tropical a claros ocasionados por la caída de árboles. Revista de Biologia Tropical, v.35, supl.1, p.111-118, 1987.

STEPHENSON, A.G. Flower and fruit abortion: proximate causes and ultimate functions. Annual Review of Ecology and Systematics, v.12, p.253-279, 1981.

SUN, D.; DICKINSON, G.R. The competition effect of Brachiaria decumbens on the early growth of direct-seeded trees of Alphitonia petriei in tropical north Australia. Biotropica, v.28, p.272-276, 1996.

SWAINE, M.D. Ecology of tropical forest tree seedlings. Paris: UNESCO, Parthenon, 1996. 323p.

THOMPSON, K. The funcional ecology of seed banks. In: FENNER, M. Seeds : ecology of regeneration in plant communities. Wallingford: CAB International, 1993. p.231-258.

TROUSE, A.C. Jr.; HUMBERT, R.P. Some effects of soil compaction on the development of sugar cane roots. Soil Science, v.91, p.208-217, 1961.

UHL, C. Factors controlling successsion following slash-and-burn agriculture. Journal of Ecology, v.75, p.377-407, 1987. 
UHL, C.; BUSCHBACHER, R.; SERRÃO, A.S. Abandoned pastures in eastern Amazonia. I. patterns of plant succession. Journal of Ecology, v.76, p.663-681, 1988.

UHL, C.; CLARK, K.; CLARK, H.; MURPHY, P. Early plant succession after cutting and burning in the upper Rio Negro region of the Amazonian Basin. Journal of Ecology, v.69, p.631-649, 1981.

UHL, C.; NEPSTAD, D.; SILVA, J.M.C.; VIEIRA, I. Restauração da floresta em pastagens degradadas. Ciência Hoje, v.13, n.76, p.22-31, 1991.

VÁZQUEZ-YANES, C.; OROZCO-SEGOVIA, A. Patterns of longevity and germination in the tropical rainforest. Annual Review of Ecology and Systematics, v.24, p.69-87, 1993.

VÁZQUEZ-YANES, C.; OROZCO-SEGOVIA, A. Fisiologia ecologica de semillas en la Estacion de Biologia Tropical "Los Tuxtlas", Veracruz, Mexico. Revista de Biologia Tropical. v.35, p.85-89, 1987.

VIEIRA, I.C.G.; UHL, C.; NEPSTAD, D. The role of the shrub Cordia multispicata Cham. As a 'succession facilitator' in a abandoned pasture, Paragominas, Amazonia. Vegetatio, v.115, p.91-99, 1994.

WHITMORE, T.C. An introduction to tropical rain forest. Oxford: Clarendon Press, 1990. $226 p$.

WHITMORE, T.C. Forty years of rain forest ecology: 1948-1988 in perspective. GeoJournal, v.19, p.347-360, 1989. 
WILLSON, M.F. Dispersal mode, seed shadows, and colonization patterns. Vegetatio, v.107/108, p.261-280, 1993.

WILLSON, M.F.; CROME, F.H.J. Patterns of seed rain at the edge of a tropical Queensland rain forest. Journal of Tropical Ecology, v.5, p.301-308, 1989.

WILLSON, M.F.; WHELAN, C.J. Variation in post-dispersal survival of vertebrate-dispersed seeds: effects of density, habitat, location, season and species. Oikos, v.57, p.191-198, 1989.

WILSON, E.O. The current state of biological diversity. In: WILSON, E.O. (Ed.). Biodiversity. Washington: National Academic Press, 1988. p.3-18.

WORLD RESOURCES INSTITUTE. Word resources 1997-1998. Oxford: University Press, 1997. 76p.

YOUNG, K.R. Deeply buried seeds in a tropical wet forest in Costa Rica. Biotropica, v.17, n.4, p.336-338, 1985.

YOUNG, K.R.; EWEL, J.J.; BROWN, B..J. Seed dynamics during forest succession in Costa Rica. Vegetatio, v.71, p.157-173, 1987.

ZAR, J.H. Biostatistical analysis. New Jersey: Prentice Hall, 1984. 718p. 